\title{
Philodendron Schott (Araceae): morfologia e taxonomia das espécies da Reserva Ecológica de Macaé de Cima - Nova Friburgo, Rio de Janeiro, Brasil ${ }^{1}$
}

\author{
Marcus Alberto Nadruz Coelho ${ }^{2}$
}

\begin{abstract}
RESUMO
O presente trabalho trata da morfologia e do estudo taxonômico das espécies do gênero Philodendron Schott, ocorrentes na Reserva Ecológica de Macaé de Cima, Distrito de Macaé de Cima, Município de Nova Friburgo, Estado do Rio de Janeiro, Brasil. Foram estudadas 10 espécies, a saber: P. altomacaense Nadruz et Mayo, P. appendiculatum Nadruz et Mayo, P. edmundoi Barroso, P. eximium Schott, $P$ fragile Nadruz et Mayo, $P$. hatschbachii Nadruz et Mayo, P. ochrostemon Schott, $P$. ornatum Schott, P. propinquum Schott e P. roseopetiolatum Nadruz et Mayo sendo 3 endêmicas da área estudada - $P$. altomacaense, $P$. fragile e $P$. roseopetiolatum. As espécies $P$. eximium, $P$. imperiale, $P$. dolosum e $P$. ornatum foram lectotipificadas e $P$. ambiguum é reduzido a sinônimo de $P$. propinquum. O tratamento taxonômico dado às espécies do gênero em apreço inclui ilustrações, descrições, distribuição geográfica, uma chave dicotômica para identificação das espécies, comentários acerca da morfologia e sobre seus ambientes naturais e classificação da categoria conservacionista pelos critérios da International Union for Conservation of Nature and Natural Resources (IUCN).

Palavras Chaves: Araceae/Philodendron/Taxonomia/Rio de Janeiro
\end{abstract}

\begin{abstract}
This study consists of morphological and taxonomic treatment of the species of the genus Philodendron Schott which occur in the Ecological Reserve of Macaé de Cima, Macaé de Cima District, Municipality of Nova Friburgo, Rio de Janeiro State, Brazil. Ten species were studied: Philodendron altomacaense Nadruz et Mayo, P. appendiculatum Nadruz et Mayo, P. edmundoi Barroso, P. eximium Schott, P. fragile Nadruz et Mayo, P. hatschbachii Nadruz et Mayo, P. ochrostemon Schott, $P$. ornatum Schott, P. propinquum Schott and P. roseopetiolatum Nadruz et Mayo. Of which three of these species are endemic to the study area, as far as presently know - $P$. altomacaense, $P$. fragile and $P$. roseopetiolatum. The species names $P$. eximium, $P$. imperiale, $P$. dolosum and $P$. ornatum are lectotypified and $P$. ambiguum is reduced to the synonymy of $P$. propinquum. The taxonomic treatment includes illustrations, descriptions, geographical distribution, a dichotomous key for identification of the species, commentary on the morphology of the species, on their natural habitats, and of their conservation status according to the criteria of the International Union for Conservation of Nature and Natural Resources (IUCN).
\end{abstract}

Keywords: Araceae/Philodendron/Taxonomy/Rio de Janeiro

\footnotetext{
${ }^{1}$ Parte da Dissertação de Mestrado apresentada à Coordenação do Curso de Pós-Graduação (Botânica) do Museu Nacional/Universidade Federal do Rio de Janeiro.

${ }^{2}$ Pesquisador Titular III do Instituto de Pesquisas Jardim Botânico do Rio de Janeiro - Rua Pacheco Leão 915, Jardim Botânico, Rio de Janeiro, RJ, CEP 22460.030
} 


\section{INTRODUÇÃO}

A família Araceae compreende cerca de 105 gêneros e aproximadamente 3300 espécies de herbáceas e trepadeiras (Grayum 1990, Mayo et al. 1997). Segundo Bogner \& Nicolson (1991) as Araceae são divididas em 9 subfamílias: Gymnostachydoideae, Pothoideae, Monsteroideae, Calloideae, Lasioideae, Philodendroideae, Colocasioideae, Aroideae e Pistioideae. A subfamília Philodendroideae inclui a tribo Philodendreae a qual pertence o gênero Philodendron Schott. A família possui ampla distribuição e é predominantemente tropical, cerca de $10 \%$ dos gêneros estendemse às zonas temperadas do norte. Está representada no Brasil por 30 gêneros, entre os quais Philodendron com, aproximadamente, 155 espécies (Mayo et al. 1994).

O gênero neotropical Philodendron Schott é um dos mais importantes na família, não somente em termos de representatividade com 350-400 espécies formalmente reconhecidas, sendo o segundo maior depois de Anthurium Schott, , mas também pela sua importância para a floricultura, como planta ornamental, pela beleza de sua folhagem. Suas espécies estão subordinadas a 3 subgêneros bem distintos em morfologia floral e vegetativa, anatomia floral e distribuição geográfica, a saber: Meconostigma (Schott) Engler, Pteromischum (Schott) Mayo e Philodendron (Mayo, 1986b). O subgênero Meconostigma, com 15 espécies, é largamente distribuído no sul do Brasil, mas estende-se ao norte pela Bacia Amazônica. Suas espécies são adaptadas a ambientes abertos e o subgênero é caracterizado pela longa zona estéril do espádice. O subgênero Pteromischum, estimado em 75 espécies, ocorre em toda a região neotropical incluindo México e as Antilhas, sendo que o seu maior centro de distribuição está nas planícies da América Central e noroeste da América do Sul. O subgênero caracteriza-se pela morfologia do caule (composto de unidades simpodiais de muitas folhas), lâmina foliar simples e bainha foliar comprida. O subgênero Philodendron, com 10 seções e 11 subseções, compreende a maioria das espécies no gênero. Pode ser caracterizado pela morfologia do caule, que é composto de unidades simpodiais de uma única folha, e da inflorescência em que a zona estéril, entre as zonas masculina e feminina, é mais curta que a zona masculina. As espécies desses dois últimos subgêneros são, na sua maioria, hemi-epífitas, epífitas e poucas são adaptadas a situações expostas.

Tanto para taxonomistas como horticultores, a circunscrição e identificação das espécies do gênero Philodendron constitui-se em um grande problema pela ausência de uma revisão geral mais recente que o tratamento de Krause (1913). Os conhecimentos taxonômicos das espécies brasileiras de que se dispõe permanecem ainda superficiais, somando-se as poucas coletas e escassas informações de campo.

A maioria dos espécimes exibe uma grande variedade morfológica, resultando em maior dificuldade no conhecimento do gênero a nível específico, devido ao reduzido número de coleções nos herbários. Até mesmo as espécies mais comuns são pouco representadas nos herbários e, da maioria das coleções, faltam anotações de campo adequadas nas etiquetas ou de dados complementares como, p.ex., fotografias, sendo, por esse motivo, de valor taxonomicamente muito limitado. Trabalhos de campo intensivo, em épocas adequadas, são necessários para o correto entendimento da taxonomia de Philodendron.

Sendo principalmente um grupo da floresta tropical, podendo ocorrer em uma variação de outros habitats incluindo brejos, afloramentos rochosos e até em regiões semiáridas, Philodendron tem sua mais rica diversidade em algumas das regiões botanicamente muito pouco conhecidas da América Tropical, tal como o Chocó da Colômbia, Peru subandino, Equador e a parte ocidental da Planície Amazônica (Mayo, 1991). Muitos novos taxa certamente esperam ser descobertos ou reconhecidos formalmente. No 
presente é impossível determinar com precisão a verdadeira dimensão específica do gênero. Sua área de distribuição é essencialmente neotropical, indo do México Central até Argentina incluindo as Antilhas (Mayo, 1989).

A escolha da Reserva Ecológica de Macaé de Cima para os estudos com o gênero, se deve ao fato de ser a área um dos poucos remanescentes de vegetação primária de Mata Atlântica, possuindo uma grande diversidade de lianas, epífitas e hemi-epífitas das quais fazem parte o gênero Philodendron. Em conseqüência dos trabalhos realizados por cientistas do Jardim Botânico do Rio de Janeiro desde 1987, relativos ao Programa Mata Atlântica, existe facilidade de infra-estrutura na área. Foram encontrados, até agora, 10 espécies para o gênero ocorrentes na área.

Atualmente, pela falta de especialistas na família, no Brasil, torna-se necessário um estudo deste grupo, com a finalidade de melhorar o conhecimento das espécies, tanto do ponto de vista morfológico como taxonômico, fornecer dados ecológicos para contribuir com o conhecimento da flora da Mata Atlântica e conhecer melhor os recursos nativos de plantas ornamentais brasileiras, com vistas a sua utilização em paisagismo.

\section{Descrição da área}

Criada pelo decreto número 156, de 03 de janeiro de 1990, da Prefeitura Municipal de Nova Friburgo, a Reserva Ecológica de Macaé de Cima, situada no Município de Nova Friburgo, RJ, possui uma superfície de 7103 ha, com latitudes de $22^{\circ} 21^{\prime} \mathrm{S} / 22^{\circ} 28^{\prime} \mathrm{S}$ e longitude de $42^{\circ} 37^{\prime} \mathrm{W} / 42^{\circ} 35^{\prime} \mathrm{W}$, e tem como afluentes os Rios das Flores e Macaé. Seus pontos culminantes são a Pedra do Faraó (1719 m.s.m), a Pedra de São Caetano (1657m.s.m) e a Pedra Bicuda (1499m.s.m). É limitada ao sul pelo Município de Silva Jardim e a oeste pelo Município de Cachoeira de Macacu, possuindo como referências orográficas a Serra de Macaé de Cima ao norte, ao sul a
Serra de São João e a sudeste a Serra do Taquaruçu (Fig. 1) (Lima et Guedes-Bruni, 1997).

O Município de Nova Friburgo faz parte da região sudeste brasileira onde possui uma notável diversidade climática, caracteriza-se pelo predomínio do clima subquente. O principal determinante desta série de variedades climáticas é a orografia desta área, tanto no que se refere à temperatura quanto à precipitação (Nimer, 1989).

As temperaturas médias anuais do Município de Nova Friburgo, durante o período de 1961 e 1990, variaram com a mínima de $13.8^{\circ} \mathrm{C}$ e a máxima de $24.3^{\circ} \mathrm{C}$. Fevereiro apresentou-se como mês mais quente com temperatura média de $27.6^{\circ} \mathrm{C}$ e julho como mês mais frio com temperatura média de $9.5^{\circ} \mathrm{C}$. A precipitação total anual é de $1246.3 \mathrm{~mm}$, a evaporação total anual é de $605.3 \mathrm{~mm}$ e a umidade relativa anual é de $80 \%$ (Depto. Nacional de Meteorologia, 1992). Provavelmente, já que não se dispõe dos dados climatológicos da área, a Reserva Ecológica de Macaé de Cima apresenta-se mais úmida com temperatura mais baixa que a encontrada na cidade de Nova Friburgo.

O substrato rochoso é constituído essencialmente de rochas intrusivas e metamórficas Pré-Cambrianas, que afloram extensamente na maior parte da área. Suas rochas são gnaisse e milonito nas Unidades Desengano, São Fidélis e Santo Eduardo, granitóides de estrutura homófana e fluidal na Pedra Bicuda e Faraó, e Depósitos Aluvionares numa pequena região do Rio Macaé. Os solos da região são do tipo Cambissolo Alico "A" moderado e proeminente. A geomorfologia compreende faixas de dobramento remobilizado, modelado de dissecação diferencial, sendo que a dissecação é marcada por controle estrutural, definido apenas pela variável aprofundamento da drenagem (Oliveira et al., 1983; Lima et Guedes-Bruni 1997). 


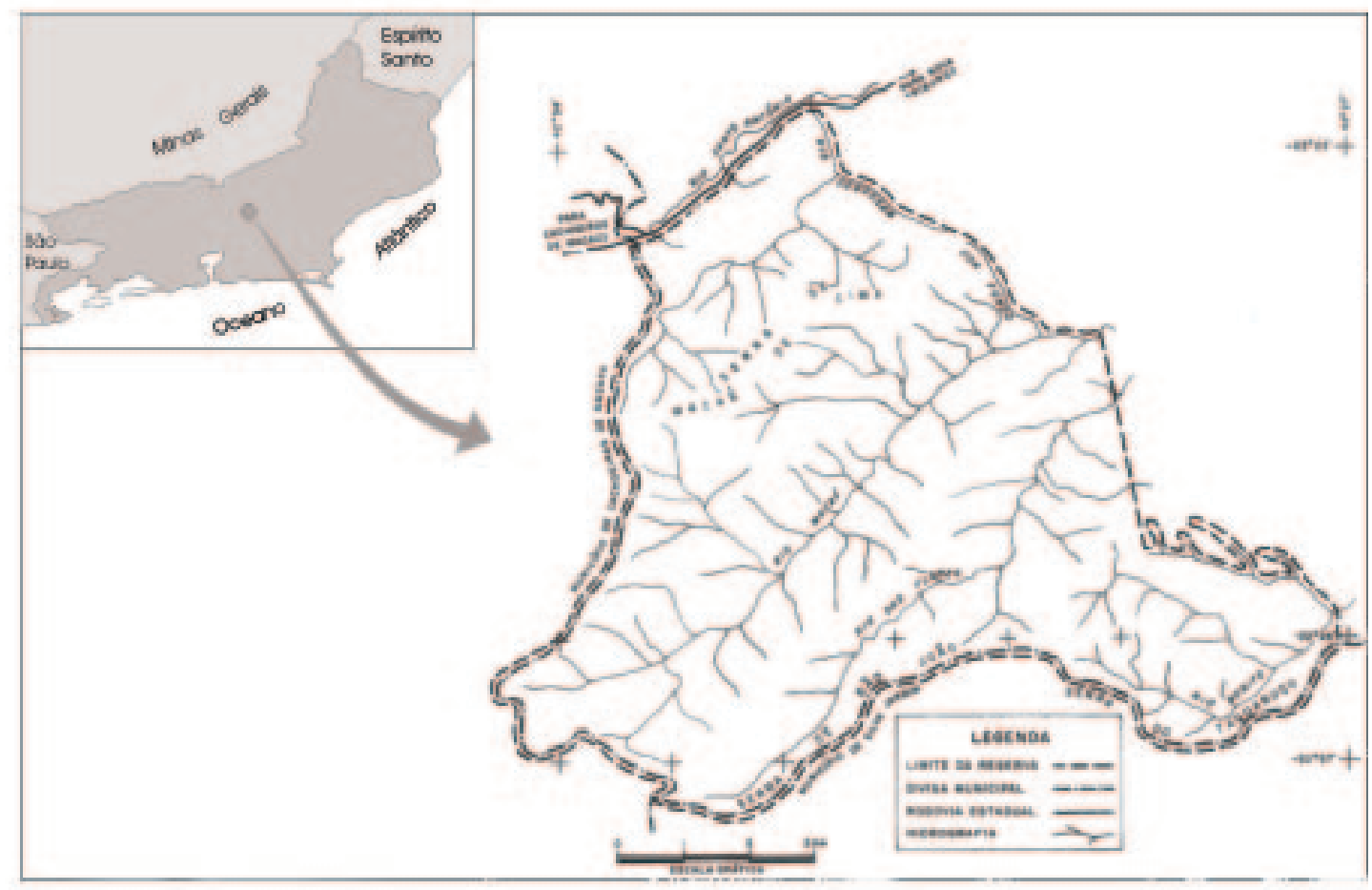

Figura 1 - Mapa da Reserva Ecológica de Macaé de Cima - Fonte: Programa Mata Atlântica/JBRJ

\section{Vegetação}

O Município de Nova Friburgo, onde está situada a Reserva Ecológica Macaé de Cima, pertence à Serra do Mar, e consequentemente, sua vegetação se caracteriza pela Mata Pluvial Tropical Costeira (Hueck, 1972). Esta mata deve sua existência à grande umidade do ar, trazida pelos ventos marítimos, com altas precipitações (1700 a $2000 \mathrm{~mm}$ ) e temperaturas (médias anuais de $23^{\circ}$ a $25^{\circ} \mathrm{C}$ ).

$\mathrm{Na}$ área da Reserva Ecológica de Macaé de Cima foram inventariados 1011 táxons de fanerógamos, sendo que esse grupo é composto quase que exclusivamente de Angiospermas, já que apenas duas espécies são Gimnospermas.

Analisando a distribuição das espécies pelo tipo de hábito, constatou-se que $31 \%$ são herbáceo/arbustivas e $18 \%$ trepadeiras, demonstrando a importância das plantas não arbóreas na riqueza de espécies da flora de Macaé de Cima. Esses dados podem ser comprovados através da diversidade e abundância ali encontradas de famílias exclusivamente arbustivo/herbáceas como Orchidaceae, Araceae, Bromeliaceae e Piperaceae (Lima et Guedes Bruni, 1994).

$\mathrm{Na}$ área da Reserva as espécies arbóreas representam $51 \%$ das fanerógamas até agora inventariadas, distribuídas em 58 famílias, onde Melastomataceae, Rubiaceae e Leguminosae possuem o maior número de espécies. As epífitas correspondem a $17 \%$ do total, com 145 espécies até agora conhecidas, onde 64 delas pertencem as monocotiledôneas. Esse número apresenta-se baixo já que o inventário deste grupo é incompleto na área (Lima et Guedes Bruni, 1994).

$\mathrm{O}$ interior da mata caracteriza-se pela presença de 2 estratos arbóreos: $O$ estrato inferior que apresenta arbustos e árvores com alturas entre 2 e $12 \mathrm{~m}$ e tem entre seus representantes exemplares de Mollinedia micrantha (Monimiaceae), Psychotria velloziana (Rubiaceae), Hedyosmum brasiliensis (Chloranthaceae) e Cordia 
Philodendron Schott (Araceae): morfologia e taxonomia das espécies da Reserva Ecológica de

ecalyculata (Boraginaceae), entre outros. O estrato intermediário é formado por árvores com alturas entre 12 e $20 \mathrm{~m}$, tendo como espécies características, entre outras, Euterpe edulis (Palmae), Mollinedia gilgiana, $M$. salicifolia (Monimiaceae), Myrceugenia scutellata (Myrtaceae). Sobrepondo-se às copas, emergem exemplares de Beilschmiedia rigida (Lauraceae), Myriocarpus frondosus (Leguminosae), Croton organensis (Euphorbiaceae) e Ocotea porosa (Lauraceae), esta última com um de seus exemplares alcançando a altura de $38 \mathrm{~m}$. A mata é rica em epífitas e grupos de samambaias. A grande umidade do ar permite o desenvolvimento de plantas de várias famílias, e as mais representativas são Orchidaceae, Araceae, Bromeliaceae e Polypodiaceae (Programa Mata Atlântica, 1990).

O estrato superior da mata é caracterizada como típica mata úmida de neblina que, na Reserva, está entre 1200 e $1400 \mathrm{~m}$ de altitude. As árvores apresentam-se com troncos baixos e deformados e densamente cobertos por musgos. A cobertura vegetal toma a forma de uma mata arbustiva de 6 a $8 \mathrm{~m}$ de altura. As famílias mais importantes deste tipo de vegetação são Myrtaceae, Melastomataceae, Compositae arbóreas e arbustivas, inúmeras epífitas, principalmente as bromélias, orquídeas, líquens e pteridófitas.

Existem lugares em que as matas primitivas foram destruídas pela ocupação humana, formando uma vegetação secundária densa com exemplares de Rubiaceae, Palmae, Flacourtiaceae e Melastomataceae, entre outras.

A Reserva Ecológica de Macaé de Cima possui, até o momento, 24 espécies endêmicas, demonstrando a singularidade da flora local caracterizando a área como reduto de diversidade e endemismo do ecossistema Mata Atlântica (Programa Mata Atlântica, 1990).

Através de levantamento nos herbários do Estado do Rio de Janeiro, foram encontradas 3 espécies do gênero Philodendron (P. altomacaense, P. appendiculatum e P. edmundoi) para a Reserva, sendo que, com o decorrer das expedições à área, principalmente com a implantação do Programa Mata Atlântica em 1987, esse número cresceu para 10 , mostrando a riqueza da família e a importância da continuidade e intensificação de coletas para constatar a diversidade do grupo na flora local.

\section{MATERIAL E MÉTODOS}

Para o estudo taxonômico das espécies do gênero Philodendron ocorrentes na Reserva Ecológica de Macaé de Cima, foi realizado um levantamento bibliográfico e utilizados espécimes de coleções vivas e herborizadas, inclusive os tipos e fotos de tipos e pranchas depositados nos principais herbários do Estado do Rio de Janeiro e nos herbários do Royal Botanic Gardens Kew e Natural History Museum (Londres, Inglaterra), cujas siglas encontram-se citadas no texto segundo o Index Herbariorum (Holmgren et al., 1981).

O trabalho de campo foi realizado com intensivas coletas de material botânico durante 19 excursões à área entre os anos de 1992 e 1994. Essas coletas foram realizadas nas seguintes localidades: estrada que atravessa o Sítio Sophronites; área do Sítio Sophronites; Pedra Bicuda; caminho para a Serra dos Pirineus; estrada principal que corta a Reserva; estrada para o Cassino; Fazenda Ouro Verde e Sítio Fazenda Velha. O Sítio Bacchus foi também visitado, apesar de estar fora da Reserva, encontra-se muito próximo da mesma, apresentando uma vegetação bem preservada.

As espécies foram observadas em seus habitats naturais e confeccionou-se fotos para a ilustração de detalhes das folhas e inflorescências, e desenhos a nanquim para a esquematização das estruturas reprodutivas com auxílio de microscópio estereoscópico. Os caracteres de coloração das partes vegetativas e da inflorescência foram utilizados na chave de identificação tendo em vista que os mesmos são importantes para a taxonomia das espécies 
e se perdem após o processo de secagem do material.

A técnica de coleta e herborização seguiu o descrito por Croat (1985). Todo o material coletado encontra-se depositado no herbário do Jardim Botânico do Rio de Janeiro (RB);

As medidas das partes vegetativas e florais foram tomadas apenas dos materiais coletados na Reserva Ecológica de Macaé de Cima. As medidas do diâmetro do pecíolo, pedúnculo e zonas da inflorescência foram obtidas das regiões medianas desses órgãos. As medidas do óvulo inclui o funículo.

$\mathrm{Na}$ descrição da morfologia foliar, usouse a nomenclatura proposta por Stearn (1993) e, para as lâminas cordiformes e sagitadas, a de Mayo p.p. (1991). As denominações referentes a inflorescência e infrutescência foram baseadas em Mayo (1986 b).

As categorias de ameaçadas ou sobre o risco de extinção, foram baseadas em Carauta (1989).

Os dados referentes à floração, frutificação e observações ecológicas foram obtidos das espécies durante a realização dos trabalhos de campo e das etiquetas de herbário daquelas ocorrentes na Reserva.

Os dados referentes a distribuição das espécies no Brasil foram obtidos através de bibliografia e etiquetas de herbário.

Para as fotografias usou-se máquina Canon AE-1 Program, tanto para fotos em papéis quanto diapositivos.

Segue, abaixo, a lista dos herbários visitados para exame dos materiais: BM Natural History Museum, Londres, Inglaterra; FCAB - Herbário Friburguensis, Nova Friburgo, RJ; GUA - Herbário "Alberto Castellanos", Rio de Janeiro, RJ; HB Herbarium Bradeanum, Rio de Janeiro, RJ; K - Royal Botanic Gardens, Kew, Londres, Inglaterra; R - Herbário do Museu Nacional, Rio de Janeiro, RJ; RB - Herbário de Jardim Botânico do Rio de Janeiro, Rio de Janeiro, RJ; RBR - Herbário da Universidade Federal Rural do Rio de Janeiro, Itaguaí, RJ.

\section{HISTÓRICO DO GÊNERO Philodendron Schott}

A história do gênero Philodendron iniciou-se com a primeira descrição publicada, em 1829, apresentada numa forma muito abreviada em um jornal vienense, pouco conhecido, chamado "Wiener Zeitschrift für Kunst, Literatur, Theater und Mode" (Mayo 1990a). Schott, em seu artigo, preocupou-se com a separação de dois novos gêneros de Araceae, Philodendron e Syngonium, do, até aqui, heterogêneo Caladium.

Embora, aparentemente trivial à primeira vista, o novo conceito genérico de Schott marcou, talvez, o mais importante avanço histórico na sistemática da família Araceae. Pouco tempo depois, em 1832, sintetizou seu trabalho em um novo sistema da família publicado no "Meletemata Botanica". Neste trabalho ele também apresentou o primeiro esquema infragenérico para o gênero Philodendron, que foi baseado exclusivamente nos caracteres florais, e incluiu duas "secções" monoespecíficas (Meconostigma e Sphincterostigma), caracterizadas pela estrutura do estigma que, mais tarde, foram reunidas por Engler dentro do subgênero Meconostigma. No total, somente 10 espécies de Philodendron são mencionadas, e isto durou até 24 anos mais tarde quando ele publicou um tratamento mais completo (Schott 1856).

Endlicher, em 1837, publicou um tratamento de Philodendron que foi baseado exatamente no "Meletemata..." de Schott (1856), diferindo somente na inclusão de uma descrição detalhada do gênero. Outra grande contribuição para a sistemática das aráceas nesse período foi o tratamento dado a família por Blume em 1837. Ele não fez, entretanto, nenhum tratamento com Philodendron. Quatro anos mais tarde, Kunth, em 1841, publicou a primeira classificação do gênero que tratou das espécies individualmente. Seus taxa infragenéricos e seus caracteres diagnósticos permaneceram inalterados, em relação ao tratamento do "Meletemata..." de Schott 
(1856). Embora ele tenha incluído espécies que foram, mais tarde, transferidas para outro gênero, o relato de Kunth (1841) foi uma importante contribuição em que ele sumarizou, completamente, a literatura prévia, publicou novas espécies e combinações e enquadrou no gênero Philodendron as espécies que, mais tarde, seriam reconhecidas para o subgênero Pteromischum.

A primeira revisão completa de Schott (1856), a nível de espécie, foi publicada em seu "Synopsis Aroidearum", um trabalho planejado para cobrir a família toda, mas que não continuou além do primeiro volume. $\mathrm{Na}$ época, muito mais espécies de Philodendron foram descritas das coleções enviadas para a Europa, em números sempre crescentes, dos trópicos do Novo Mundo. No "Synopsis..." foram descritas 99 espécies, um aumento três vezes maior que o relato de Kunth (1841). A classificação de Schott é aqui completamente diferente do tratamento de 1832, que tinha sido baseado nos caracteres florais. A classificação final foi publicada no "Prodromus Systematis Aroidearum" (Schott, 1860). Esse tratamento não difere em caráter essencial do relato anterior, aumentando somente o número de espécies. Independentemente do publicado, o autor deixou um incomparável arquivo de ilustrações que, desde então, tem sido muito usado por importantes estudiosos da família (Schott, 1984). Consiste de cerca de 4400 ilustrações a lápis e aquarela, incluindo muitas espécies de Philodendron (208 ilustrações), que são uma referência essencial na interpretação dos táxons descritos por Schott. As ilustrações coloridas foram feitas usando plantas cultivadas no Jardim Imperial do Palácio de Schoenbrunn, Viena, e estão entre as mais belas ilustrações botânicas conhecidas.

A primeira classificação de Engler do gênero Philodendron foi publicada no tratamento das Aráceas que foi escrito para a "Flora Brasiliensis", em 1878, onde ele apresentou uma sinopse completa do gênero anexada ao relato detalhado das espécies brasileiras. Ele descreveu poucas novas espécies em sua publicação e o número de espécies reconhecidas caiu para 116 do total de 135 dado por Schott em 1860.

Em 1879 Engler publicou um segundo tratamento do gênero em sua monografia de Araceae para o "Prodromus" de Alphonse de Candolle. Esse tratamento difere do anterior apenas pela adição de um pouco mais de espécies, elevando o total para mais de 120 (Mayo 1990a). Sua terceira revisão foi publicada 20 anos mais tarde (Engler 1899), e é, essencialmente, a classificação usada hoje. Muitas novas espécies foram descritas, especialmente provenientes da Colômbia, Equador e América Central, onde a exploração botânica estava mais ativa. Como resultado, o número total reconhecido tinha crescido para 167 espécies.

A revisão de Krause (1913), publicada na grande série de monografias de Engler entitulada "Das Pflanzenreich", mudou pouco a classificação de 1899 de Engler, mas adicionou muitas novas espécies, alcançando o gênero um total de 222. Sua mais importante característica é o grande número de ilustrações no texto, tornando-o mais prático do que qualquer revisão até então realizada. Essa foi a última tentativa para um tratamento completo do gênero Philodendron. Os fundamentos da classificação têm permanecido os mesmos desde o relato de Schott em 1856, isto é, cerca de 20 grupos de espécies são conhecidos pela combinação de alguns poucos caracteres.

Desde a revisão do "Pflanzenreich..." de Krause (1913), nenhum outro esforço foi feito para sintetizar sistematicamente dados dentro de uma nova classificação para o gênero. Entretanto, muitos estudos têm sido efetuados e um grande número de informações têm se acumulado desde aquela época. Levantamentos de espécies de muitos países neotropicais têm sido feitos, geralmente, no contexto de uma "flora" regional ou nacional. Acima de 135 novas espécies foram descritas na literatura taxonômica desde 1920, elevando o total para quase 400 , embora esse número leve em conta o número das espécies que têm 
caído em sinonímia desde aquela data.

Nos últimos anos verificou-se um rápido crescimento de interesse pelo gênero. Mayo (1986b, 1988, 1989, 1990a e 1991) fez um detalhado estudo da anatomia da inflorescência, revisou o subgênero Meconostigma, confirmou o subgênero Philodendron como um táxon bem definido e propôs uma nova nomenclatura infragenérica para o gênero. Grayum (Jardim Botânico do Missouri) vem estudando o subgênero Pteromischum e Croat (Jardim Botânico do Missouri) está revisando as espécies da América Central (apud Mayo, 1990a).

De longe, a mais importante contribuição para o moderno conhecimento do gênero tem sido feita por G.S. Bunting (1975, 1980, 1984, 1986, 1987 e 1988), pelo seu interesse especial em Philodendron por mais de 20 anos. Seu trabalho envolve muitos aspectos, incluindo nomenclatura, cultivo de espécies, anatomia vegetativa, bem como taxonomia. Novos dados sobre muitos outros aspectos da biologia de Philodendron foram publicados no curso de levantamentos gerais da família nas áreas de etnobotânica, citologia, palinologia, química, morfologia, venação foliar, anatomia vascular e floral (Mayo, 1986b).

\section{RESULTADOS E DISCUSSÃO}

\section{Considerações Morfológicas}

\subsection{Hábito}

As espécies do gênero Philodendron, ocorrentes na Reserva Ecológica de Macaé de Cima, exibem hábitos hemi-epífitos lianescentes, terrestres rizomatosos e rupícolas rastejantes.

As espécies do subgênero Pteromischum parecem ser exclusivamente hemi-epífitas lianescentes, isto é, elas são conectadas ao solo por raízes alimentadoras embora a maior parte do seu caule desenvolve-se anexado aos troncos de árvores por raízes grampiformes e freqüentemente se reproduz, vegetativamente, por ramos flageliformes.

No subgênero Philodendron, ainda que a maioria das espécies sejam hemi-epífitas lianescentes, variam grandemente em estatura e no comprimento dos internós. Plantas terrestres e rizomatosas rupícolas ocorrem neste subgênero, este último sendo comum na seção Baursia.

\subsection{Morfologia do caule}

Os caules jovens são monopodiais em todos os subgêneros, e produzem uma sucessão de folhas alternadas com bainhas bem desenvolvidas, cada uma subtendendo um simples botão axilar primário (Fig. 2a.). $\mathrm{Na}$ maioria das espécies, após um número indeterminado de folhas, a transição para crescimento simpodial monofilo ocorre. Cada unidade do simpódio consiste de um profilo, uma folha normal com uma bainha muito reduzida e uma inflorescência terminal abortada (Fig. 2.b.). O crescimento, então, continua através de um meristema axilar primário, na axila do profilo, que começa a crescer desde a sua formação no meristema apical (crescimento siléptico). Um broto secundário ou adventício também se forma na mesma axila, mas este fica dormente, e só desenvolvese se houver dano no ápice do caule (crescimento proléptico). O caule da planta adulta é assim um simpódio, composto de uma série de unidades simpodiais, cada uma constando de um ramo da unidade anterior. $\mathrm{O}$ ramo de prolongamento (a próxima unidade) desenvolve-se na axila da segunda folha abaixo da espata (esta folha no subgên. Philodendron é o profilo).

Após um indeterminado número de tais unidades simpodiais, a planta pode produzir uma ou mais inflorescências, dependendo de um número de fatores tais como iluminação, tamanho ou vigor. Quando em floração, o meristema apical, da última unidade simpodial, desenvolve-se inteiramente formando uma inflorescência, e a bainha da folha, pelo que é subtendida, é normalmente maior que aquelas das folhas em unidades simpodiais precedentes (Fig. 2.c.). Em muitas espécies uma série de unidades simpodiais florais podem resultar depois do desenvolvimento da primeira 
Philodendron Schott (Araceae): morfologia e taxonomia das espécies da Reserva Ecológica de

inflorescência terminal. O simpódio floral difere do vegetativo pelo que cada unidade consiste, somente de um profilo seguido por uma inflorescência (Fig. 2.d.). Cada unidade do simpódio floral desenvolve-se na axila do profilo da unidade anterior. Unidades simpodiais florais sucessivas são formadas na axila ou de uma folha normal ( segunda unidade simpodial floral) ou do profilo da unidade simpodial precedente $(3,4,5 \ldots$ unidades simpodiais florais) (Fig. 2.d.).

A arquitetura do sistema caulinar no subgênero Pteromischum é diferente do padrão exatamente descrito acima no qual os ramos da floração não são unidades simpodiais monofilos mas "simpódios pleiofilos", isto é, cada ramo da floração tem um número indeterminado de folhas normais antes da inflorescência terminal. As folhas normais sempre têm bainhas bem desenvolvidas, isto é, são homólogas com as folhas jovens do padrão de crescimento normal de Philodendron subgên. Philodendron e Meconostigma (Fig. 3.b.).

Nas espécies brasileiras somente uma inflorescência terminal simples é produzida nos ramos floridos do subgên. Pteromischum. Ocasionalmente, entretanto, um simpódio floral de duas inflorescências pode ser observado. Na revisão do subgênero Pteromischum, Grayum (1996) estabelece uma nova seção que se caracteriza pela presença de simpódios florais de 2 ou mais inflorescências, o trabalho está em fase de publicação impossibilitando maiores dados a respeito do assunto. A segunda unidade simpodial floral surge na axila da última folha normal como em simpódios florais nos outros subgêneros (Fig. 3.b.).

Todas as espécies do subgênero Philodendron têm crescimento simpodial monofilo em caules adultos. Os internós de uma unidade simpodial diferem em comprimento $\mathrm{O}$ internó entre o profilo e a folha normal é extremamente reduzido, enquanto o hipopódio, isto é, o internó entre o profilo da primeira unidade e o profilo da segunda, é alongado (Fig. 2.b. e 2.c.). O internó hipopodial constitui a principal fonte de alongamento do caule deste subgênero.

O simpódio floral varia um tanto nesse subgênero e requer mais investigação (Mayo, 1986b). As inflorescências podem ser solitárias ou podem formar um simpódio com até pelo menos 11 inflorescências. Este normalmente segue a seqüência descrita anteriormente (Fig. 2.d.)

A posição das escamas intravaginais (tricomas multicelulares escamiformes encontrados na região axilar do profilo ou da folha monopodial ou abaixo destes) também demonstra uma diferença no padrão de alongamento nos dois subgêneros. No subgên. Philodendron as escamas são sempre encontradas imediatamente acima das cicatrizes do profilo nos internós maduros. Em todas as espécies do subgên. Meconostigma com internós apreciáveis, as escamas, quando presentes, são encontradas imediatamente abaixo do profilo e freqüentemente ao redor das cicatrizes das folhas normais.

\subsection{Ramos flageliformes}

Em algumas espécies de Philodendron ocorre uma forma modificada de crescimento do caule, chamado ramos flageliformes. É um eixo que possui a função de deslocar, rapidamente, a posição do meristema apical no espaço. Isto representa uma estratégia para exploração do espaço nas condições ecológicas limitantes. A característica de um ramo flageliforme, não considerando as já mencionada, inclui morfologia do broto monopodial, a redução das folhas para catafilos ou, ao menos, para folhas com lâminas muito reduzidas e o desenvolvimento de internós finos e longos.

\subsection{Raízes}

A raiz primária ou radícula é de curta duração nas Araceae, e raízes adventícias subseqüentes desenvolvem-se do caule. Dimorfismo ocorre em raízes de Philodendron, ou seja, dois tipos são apresentados: raízes curtas grampiformes em forma de cabeleira adesiva, geralmente estendendo-se em ângulo reto ao caule 
prendendo a planta à superfície trepadora; e raízes longas alimentadoras que descem ao solo com a finalidade de absorver água e nutrientes. As raízes alimentadoras atingem grandes comprimento devido às posições altas das plantas no andar superior das florestas. Uma vez no interior de solo úmido e escuro ou de fissuras elas se ramificam formando uma densa rede. Raízes aéreas desse tipo são extremamente flexíveis e fortes.

\subsection{Folhas}

Dependendo da posição da folha no ramo, pode-se ter uma das seguintes formas:

-Folha normal: isto é, a folha de uma planta adulta com lâmina plenamente desenvolvida;

-Catafilo: folha em que a lâmina falta, restando apenas a parte correspondente a bainha peciolar;

-Profilo: a primeira folha de um ramo, em Philodendron o profilo tem a forma de um catafilo.

As folhas em Philodendron são formadas por pecíolo, bainha e lâmina (Fig. 3.a.). O pecíolo possui caráter taxonômico muito importante; sua forma, em corte transversal, varia de cilindrico até aplanado com alas, passando por aplanado a canaliculado na face superior. Pode ser provido de protuberâncias como verrugas e estrias, até coberto por pêlos filiformes.

A bainha varia grandemente, dependendo do subgênero. Em Pteromischum possui o mesmo comprimento do pecíolo ou quase, podendo ser expandida ou fechada. Em Philodendron e Meconostigma a bainha não ultrapassa a metade do comprimento do pecíolo, chegando a ser insignificante em alguns casos e apresenta-se sempre fechada.

A lâmina foliar em Philodendron exibe uma larga variedade na forma. As simples linear-lanceolada a ovada, elíptica e obovada são comuns no subgênero Philodendron e no subgênero Pteromischum. As formas de lâmina mais comuns são as cordadas, sagitadas e hastadas, e ocorrem em ambos os subgên. Philodendron e Meconostigma. Outras formas de lâminas encontradas são lobadas, pinatifidas, trifidas, pedatisectas, pinatisectas e trisectas.

Philodendron não é, de modo algum, o único gênero das aráceas a exibir folhas dos tipos acima mencionadas. Estes tipos diversificados são encontrados em muitos outros gêneros, parecendo, conseqüentemente, que a transição entre essas formas é provavelmente fundamentada em mudanças relativamente triviais do padrão de ontogenia foliar.

\subsection{Inflorescência}

Dentro do gênero Philodendron existe uma grande variação de morfologia da inflorescência. Os caracteres comuns de todas as inflorescências de Philodendron são: o pedúnculo quase sempre relativamente curto, espata ereta em completa floração e persistente até o amadurecimento do fruto, normalmente diferenciada numa parte convoluta inferior - o tubo - e uma parte superior, mais ou menos expandida - o limbo ou lâmina. A parte apical da espata abre largamente na antese e então se fecha em torno do espádice posteriormente. O espádice é monóico com flores unissexuais faltando perigônio. As flores femininas dispostas na base e as masculinas na parte superior, geralmente são separadas por uma zona de flores estéreis masculinas (estaminodiais). Raramente existe uma zona de flores masculinas estéreis também no ápice (Fig. 3.c.). Há secreção de resina na inflorescência durante a antese.

No início da antese o limbo da espata distende-se acima de uma constrição central, e o tubo dilata-se levemente na maturidade para formar uma distinta cavidade ao redor das flores pistiladas. $O$ grau de constrição na junção entre tubo e limbo varia consideravelmente. No subgênero Pteromischum a constrição da espata é fraca ou falta, mas no subgên. Philodendron pode ser muito bem marcada.

É possível que a cor interna da espata tenha uma função de atuação na polinização, sendo assim, deve haver uma relação íntima para a estrutura e funcionamento do espádice 
Philodendron Schott (Araceae): morfologia e taxonomia das espécies da Reserva Ecológica de

durante a antese. A pigmentação da superfície interna é freqüentemente presente nas espatas do subgên. Philodendron, normalmente manifestado com um limbo branco ou verde pálido contrastando com o tubo da espata escuro, geralmente carmim ou vermelho. Possivelmente a cor contrastante ajuda atrair o polinizador para a base da espata. Entretanto, visto que os besouros parecem ser os principais polinizadores de Philodendron, muitas dúvidas existem quanto ao efeito funcional da cor da espata em vista da opinião predominante que os besouros respondem mais pelo odor que pela cor. O contraste de cor do tubo da espata e o limbo faltam sempre no subgên. Pteromischum.

1.6.1. Secreções - Os canais de resina (Mayo, 1986) encontrados na zona abaxial da espata são estreitos e comparáveis aos canais de resina da folha e, provavelmente, têm uma função protetora. Na superfície adaxial da espata nos subgênero Pteromischum e também no espádice no subgênero Philodendron, a resina é secretada, durante a antese, de canais subepidérmicos mais largos. Nectários extraflorais, tanto pigmentados como não pigmentados, ocorrem nos profilos, na folha, no pecíolo, na superfície abaxial da espata e no pedúnculo de muitas espécies.

\subsection{Flores}

1.7.1. Flor masculina fértil - A flor estaminada é, geralmente, muito simples em Philodendron, sem nenhum traço de perianto e com tecas extrorsas na maioria das espécies. Num corte transversal através das flores, muito aproximadas entre si, revela-se o arranjo dos estames ao redor de um eixo floral. O número de estames por flor varia, mesmo dentro de um único espádice, de 2 a 6 , mais comumente 3 ou 4, não sendo constante. São sempre livres entre si, embora possa haver uma leve fusão basal, num grau maior ou menor dependendo da forma do receptáculo floral.

A presença de abundantes canais de resina superficiais, somente abaixo da epiderme do eixo do espádice, é um dos mais notáveis caracteres da inflorescência de muitas espécies de Philodendron. A secreção de resina dos canais situados abaixo dos estames ocorre somente no subgênero Philodendron, a medida em que é conhecida no presente. Nos subgêneros Pteromischum e Meconostigma canais de resina de pequeno diâmetro estão presentes nos mais profundos níveis do eixo do espádice, mas não existe evidência que eles secretam seu conteúdo na superfície do espádice.

1.7.2. Flor masculina estéril Estaminódios, como seu nome implica, tem sempre sido considerados como estames modificados. Estão localizados entre as flores femininas e masculinas (na zona masculina estéril mediana) ou acima destas formando um apêndice apical (zona masculina estéril apical). As zonas de flores masculinas estéreis podem estar ligadas ao aumento de calor observado no interior da espata durante a floração e, também, provavelmente como fonte de alimento para os polinizadores. Entre os mais importantes caracteres que os estaminódios e estames têm em comum estão: 1) ambos desenvolvem-se como verticilos de órgãos separados inseridos em um receptáculo floral, 2) eles são geralmente mais ou menos similares na forma, 3) ambos têm um simples feixe axilar que pode ou não ramificar distalmente, 4) ambos têm epiderme papilosa apical com muitos estômatos (Mayo 1986b).

1.7.3. Flor feminina - No gênero Philodendron as flores pistiladas consistem de 1 gineceu simples aclamideo, faltando estaminódios ou partes do perigônio. $\mathrm{O}$ gineceu é sincárpico, superior e composto de 2 a 34 carpelos; ovários unicarpelados ou uniovulados não têm sido observados.

Uma importante característica do gineceu é a presença de um canal estilar separado para cada carpelo. $\mathrm{O}$ estigma das flores adjacentes podem ser contíguos ou distantes um dos outros. Quando contíguos a zona pistilada inteira do espádice forma uma única superfície funcional simples. Se estigmas distantes representam um tipo adaptativo distinto, 
possivelmente ligado a diferentes tipos de polinizadores, não é conhecido. Todavia, um exame mais amplo desses caracteres seria conveniente (Mayo, 1986b).

O número de lóculos em Philodendron é variável. Até dentro do espádice simples o número de lóculos normalmente varia em torno de um número modal. Os números mais comuns são 4, 5 e 6 lóculos por ovário, isso junto com a ocorrência de ovários 2-3 locular sugere que as flores de Philodendron são basicamente dímeras e trímeras em proporções aproximadamente iguais.

O número de óvulos varia de um para muitos por lóculo e essa característica é de algum valor taxonômico. Dados para espécies do subgênero Pteromischum indicam o predomínio de lóculos multiovulados. Tricomas ocorrem nos funículos dos óvulos e sua ocorrência pode ser usada como caráter taxonômico a nível específico.

Placentação apical não tem sido observado em Philodendron. Placentação basal e sub-basal são muito difundidas e são presumivelmente derivadas de placentação axilar, que também ocorre.

\subsection{Polinização}

As inflorescências de Philodendron mostram características que indicam estratégias de polinização altamente específicas. Muitas espécies possuem fragrâncias e a liberação do aroma coincide, em tempo, exatamente com o hábito dos polinizadores - besouros pertencentes as famílias Rutelinae e Dynastinae. Outros insetos podem fazer visitas mas não tem nenhuma implicação na polinização.

Geralmente a polinização ocorre em duas noites subsequentes. Na primeira a espata desabrocha e as flores femininas são expostas. Besouros são atraídos por fragrâncias que são emanadas através de um aumento de temperatura provocado pela oxidação de lipídios (Mayo, 1991). A espata fecha levemente após a primeira noite, mas não o bastante para prender completamente os insetos. Contudo, dezenas de besouros podem ser encontrados no tubo da espata após a primeira noite de sua abertura. Na segunda noite a fragrância e o calor são produzidos novamente e o pólen é derramado. Nesse estágio os estigmas não estão mais receptivos, assegurando a polinização cruzada.

Logo após a liberação do pólen na segunda noite, os besouros, provavelmente por algum mecanismo envolvendo odor, secreção ou termogênese (Mayo, 1986b), são atraídos para cima na inflorescência, coincidindo com o processo de fechamento da espata que ocorre antes da saída dos besouros para novas visitas.

A maior parte dos trabalhos de biologia floral do gênero tem sido realizada em $P$. bipinnatifidum $(=P$. selloum $)$, onde Gottsberger \& Amaral (1984) fizeram o mais completo estudo de campo em polinização. Dados de outras espécies do gênero são raros e aparentam ser limitados aos relatórios de Hubbard, datados de 1895 , de $P$. giganteum e de outras 4 espécies citadas no trabalho de Leick de 1916 (apud Mayo, 1986b).

\subsection{Frutos e sementes}

A espata fecha firmemente em torno das flores e fica intacta para proteger os frutos até seu amadurecimento. Os frutos são do tipo bagas com uma a muitas sementes. Sementes no subgênero Meconostigma as vezes possuem ou sarcotesta ou funículo arilado ou ambos. As sementes de Philodendron são as menores da família e, talvez, possam aderir-se em seus dispersores (Bown 1988).

\section{Usos}

Por muitos anos, as espécies do gênero Philodendron têm sido as mais populares plantas utilizadas em interiores, principalmente porque, a grande maioria pode resistir a baixos níveis de luminosidade e ainda proporcionar uma destacada coloração verde.

$\mathrm{Na}$ natureza essas espécies preferem uma atmosfera relativamente úmida, mas no interior de casas podem sobreviver com umidade média de $30 \%$ e temperaturas internas razoáveis, exigindo apenas um mínimo de cuidado e atenção. 
Philodendron Schott (Araceae): morfologia e taxonomia das espécies da Reserva Ecológica de Macaé de Cima - Nova Friburgo, Rio de Janeiro, Brasil

Tabela 1 - Tabela de distribuição geográfica, no Brasil, das espécies do gênero Philodendron Schott ocorrentes na Reserva Ecológica de Macaé de Cima.

\begin{tabular}{|c|c|c|c|c|c|c|c|c|c|c|c|c|c|c|c|c|c|c|c|c|c|c|c|c|c|c|c|}
\hline \multirow{2}{*}{$\begin{array}{l}\text { regióes } \\
\text { estados }\end{array}$} & \multicolumn{6}{|c|}{ Norte } & \multicolumn{9}{|c|}{ Nordeste } & \multicolumn{5}{|c|}{ Centro-Oeste } & \multicolumn{4}{|c|}{ Sudeste } & \multicolumn{3}{|c|}{ Sul } \\
\hline & AC & AM & AP & PA & RO & TO & RR & $\mathrm{AL}$ & $\mathrm{BA}$ & $\mathrm{CE}$ & $\mathrm{MA}$ & PB & $\mathrm{PE}$ & PI & $\mathrm{RN}$ & $\mathrm{SE}$ & DF & $\mathrm{GO}$ & MS & MT & ES & $\mathrm{MG}$ & RJ & SP & PR & RS & SC \\
\hline P. altomacaense & & & & & & & & & & & & & & & & & & & & & & & $x$ & & & & \\
\hline P. appendiculatum & & & & & & & & & & & & & & & & & & & & & $\mathrm{x}$ & $\mathrm{x}$ & $\mathrm{x}$ & $\mathrm{x}$ & $\mathrm{x}$ & & $\mathrm{x}$ \\
\hline P. edmundoi & & & & & & & & & & & & & & & & & & & & & $\mathrm{x}$ & & $\mathrm{x}$ & & & & \\
\hline P. ехітіuт & & & & & & & & & & & & & $\mathrm{x}$ & & & & & & & & & & $\mathrm{x}$ & $\mathrm{x}$ & & & \\
\hline P. fragile & & & & & & & & & & & & & & & & & & & & & & & $\mathrm{x}$ & & & & \\
\hline P. hatschbachii & & & & & & & & & & & & & & & & & & & & & $\mathrm{x}$ & & $\mathrm{x}$ & & & & \\
\hline P. ochrostemon & & & & & & & & & & & & & & & & & $\mathrm{x}$ & & & & $\mathrm{x}$ & $\mathrm{x}$ & $\mathrm{x}$ & $\mathrm{x}$ & & $\mathrm{x}$ & $\mathrm{x}$ \\
\hline P. ornatum & $\mathrm{x}$ & $\mathrm{x}$ & & \begin{tabular}{|l|}
$x$ \\
\end{tabular} & & & $\mathrm{x}$ & & $\mathrm{x}$ & & & & $\mathrm{x}$ & & & & & & & & $\mathrm{x}$ & $x$ & $\mathrm{x}$ & $\mathrm{x}$ & & & \\
\hline P. propinquum & $\mathrm{x}$ & & & & & & & & & & & & & & & & & & & $\mathrm{x}$ & $\mathrm{x}$ & $\mathrm{x}$ & $\mathrm{x}$ & $\mathrm{x}$ & $\mathrm{x}$ & & $\mathrm{x}$ \\
\hline P. roseopetiolatum & & & & & & & & & & & & & & & & & & & & & & & $\mathrm{x}$ & & & & \\
\hline
\end{tabular}

Algumas espécies de Philodendron pertencem ao grupo mais tropical que não suportam frio, mas outras são fortes o bastante para resistir temperaturas tão baixas como $5^{0} \mathrm{C}$. Outras espécies podem resistir a um curto período de frio mas não por um longo tempo, e se não congelarem demais podem restabelecer e produzir novas folhas na primavera.

As espécies do gênero Philodendron, incluindo as ocorrentes na Reserva Ecológica de Macaé de Cima, são cultivadas ao ar livre, em locais quentes, ou mesmo em climas mais temperados, estas plantas podem ser cultivadas ao ar livre durante o período mais quente do ano e dentro de casa quando o tempo torna-se mais frio.

Algumas espécies de Philodendron (p.ex. P. ochrostemon) são usadas na medicina popular no tratamento de bronquite crônica e aguda, aplicado como cataplasma ou como banhos diários com o cozimento das folhas. A decocção também é usada como uma compressa para edemas, articulações reumáticas e úlceras. A seiva espremida das folhas serve como um rubificante (Plowman, 1969).

\section{Habitat e Distribuição Geográfica}

As espécies encontradas na Reserva Ecológica de Macaé de Cima distribuem-se, em sua maioria, pela região sudeste do Brasil, podendo eventualmente serem registradas para as regiões sul, centro-oeste, nordeste e norte (Tabela 1). Os padrões geográficos nos subgêneros Pteromischum e Philodendron são muito similares. Peru, Venezuela,
Colômbia, Panamá e Costa Rica, Equador e a região ocidental da Amazônia são todas relativamente ricas em espécies. Fracos centros de diversidade secundários ocorrem no sudeste do Brasil e México. As áreas caribenhas e o sul da América do Sul são todas pobres em espécies. A Bolívia e o Estado de Mato Grosso são, provavelmente, pouco representados por falta de coleções. $\mathrm{Na}$ bacia amazônica o número de espécies é bem menor e, nas vertentes pacíficas dos Andes, na parte setentrional da Colômbia, nas Antilhas e América do Norte, o subgênero é desconhecido (Mayo, 1988 e 1990b).

Segundo Mayo (1990b), o gênero Philodendron possui um centro de diversidade secundário significante na região de Floresta Atlântica, embora, como na maioria dos gêneros neotropicais da família Araceae, eles são mais ricos em espécies no noroeste da América do Sul.

Dentre as espécies de Philodendron, representadas no Rio de Janeiro, 10 ocorrem na Reserva Ecológica de Macaé de Cima, sendo que 3 são endêmicas da área $(P$. altomacaense, $\quad P$. fragile e $P$. roseopetiolatum), típicas das matas nebulares da região (Tabela 1).

\section{Ecologia}

O gênero é um importante componente da flora da maioria das florestas tropicais úmidas, em elevações baixas e médias, e raramente até altitudes de 1500 metros.

$\mathrm{Na}$ Reserva Ecológica de Macaé de Cima as espécies de Philodendron apresentam-se como ervas rizomatosas à 

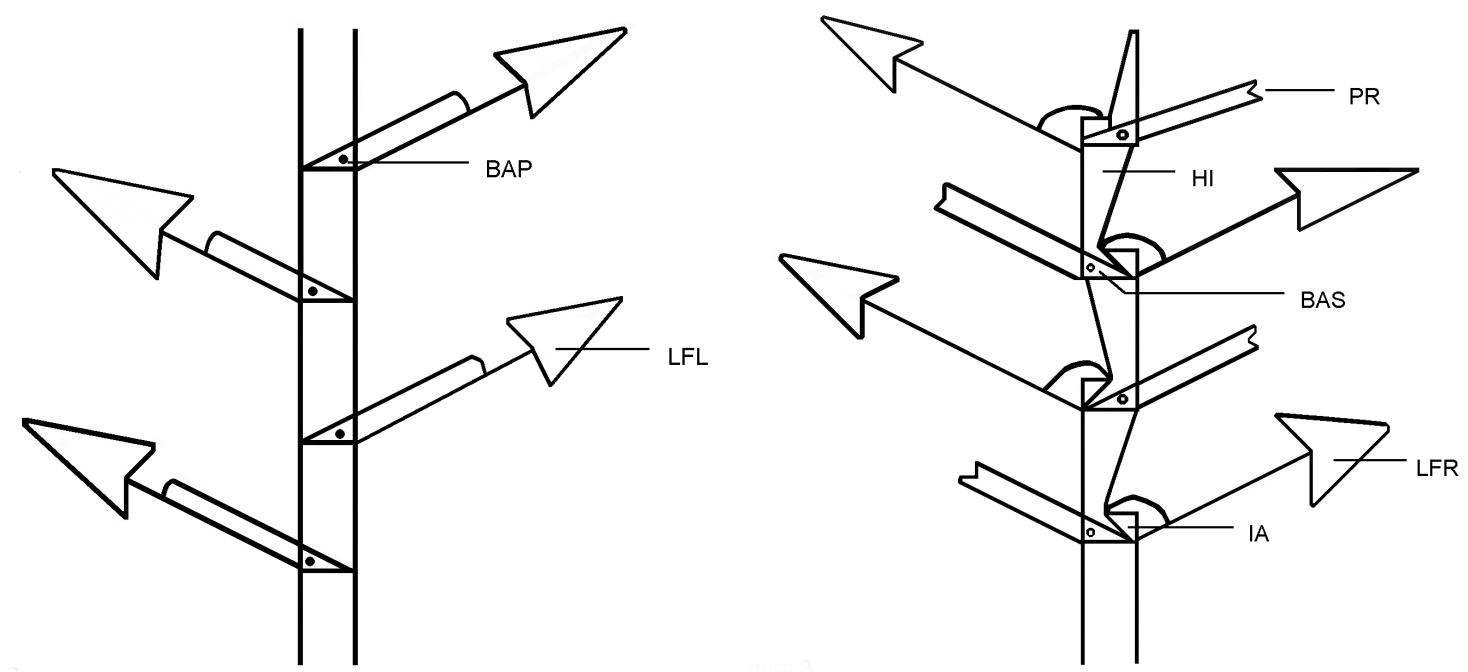

a

b
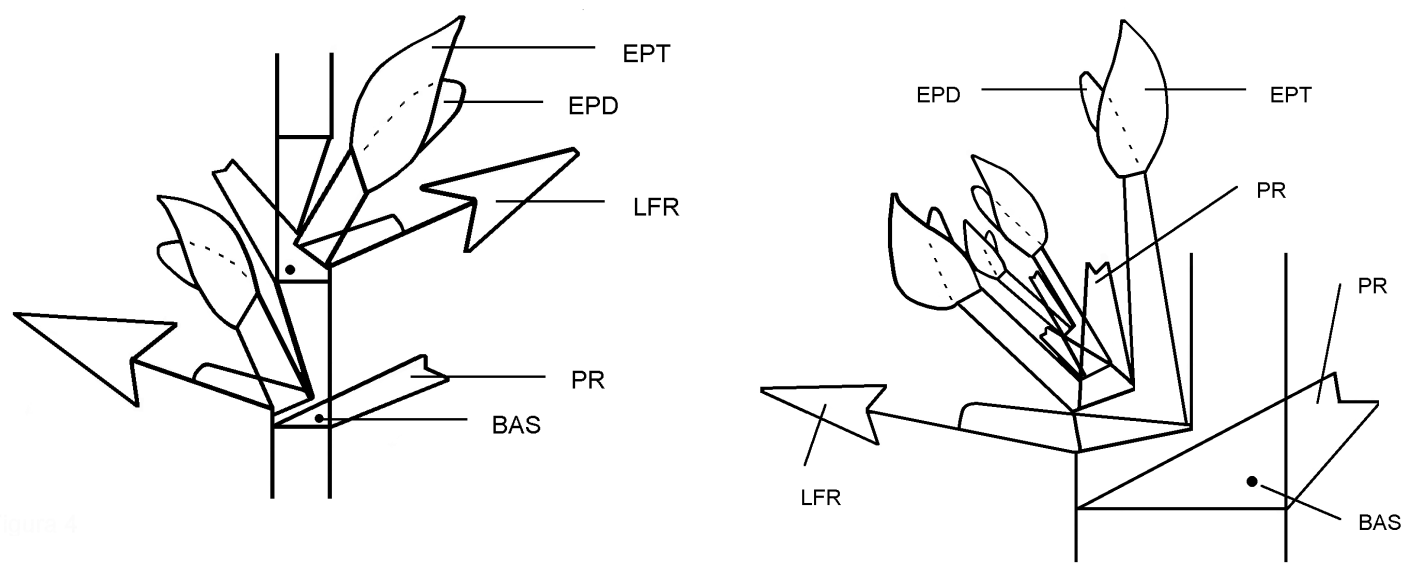

c

d

Figura 2 - Esquemas evidenciando as formas de crescimento do caule encontrados nas espécies do gênero Philodendron ocorrentes na Reserva Ecológica de Macaé de Cima. a. Crescimento monopodial - BAP - botão axilar primário; LFL lâmina foliar com bainha longa; b. Crescimento simpodial vegetativo com inflorescências abortadas - PR - profilo; HI hipopódio; BAS - botão axilar secundário; LFR - lâmina foliar com bainha reduzida; IA - inflorescência terminal abortada c. Crescimento de simpódio vegetativo com inflorescências desenvolvidas - EPT - espata; EPD - espádice; LFR - lâmina foliar com bainha reduzida; PR - profilo; BAS - botão axilar secundário; d. Crescimento simpodial monofilo com simpódio floral encontrado no subgênero Philodendron - EPT - espata; EPD - espádice; PR - profilo; BAS - botão axilar secundário; LFR - lâmina foliar com bainha reduzida.

escandentes com uma variação de exigências ecológicas. Geralmente apresentam-se como trepadores apressos em árvores (menos freqüente em rochas) nos andares inferiores, especialmente nas porções mais baixas nas matas úmidas até alcançar elevações intermediárias. Produzem, as vezes, formas trepadoras sobre a vegetação baixa e raramente se comportam como ervas terrestres, à sombra, ou como trepadeiras do dossel. Todavia, outros iniciam suas vidas como epífitas verdadeiras e, eventualmente, produzem longas raízes que alcançam o solo (desta maneira tornando-se hemi-epífitas).

A ecologia das espécies dos subgên. Pteromischum e Philodendron ocupam, predominantemente, lugares sombreados. Poucas são adaptadas para os nichos 


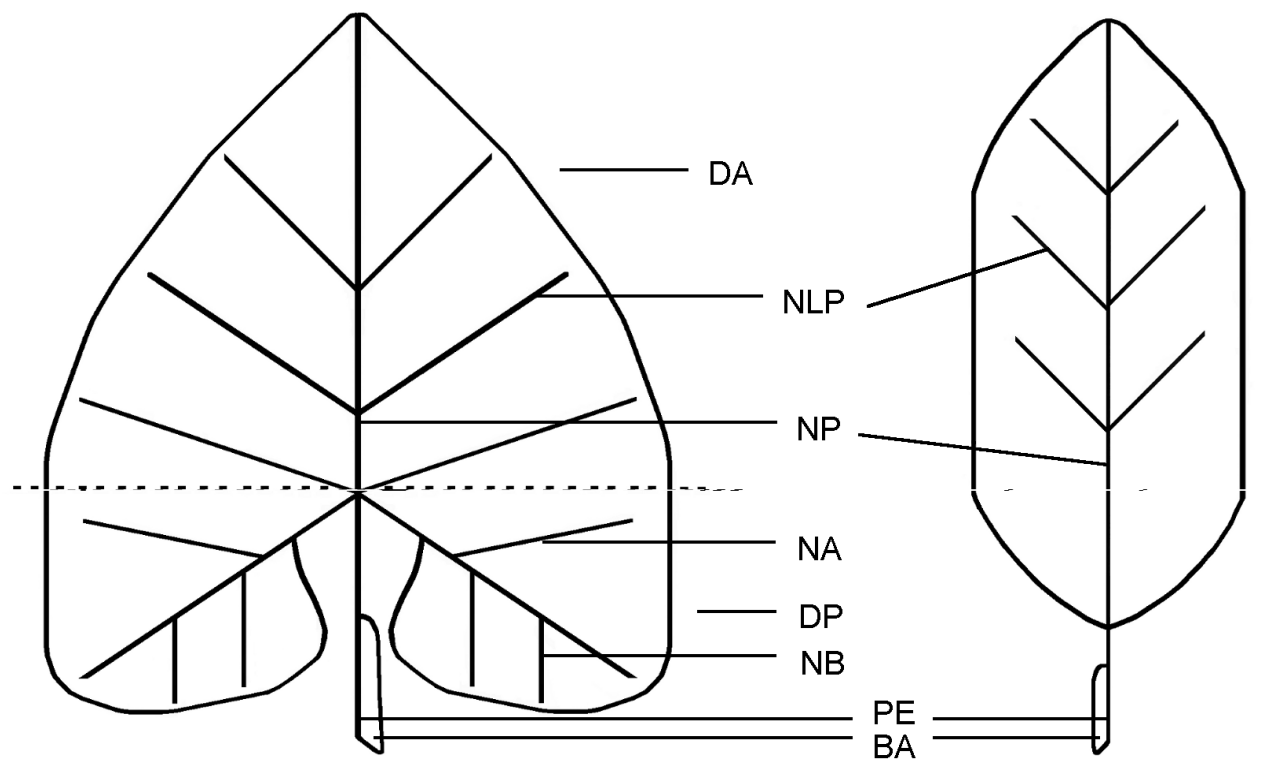

a

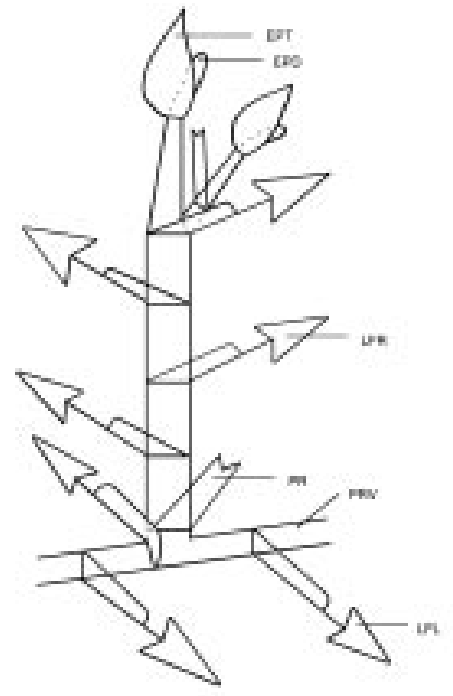

b

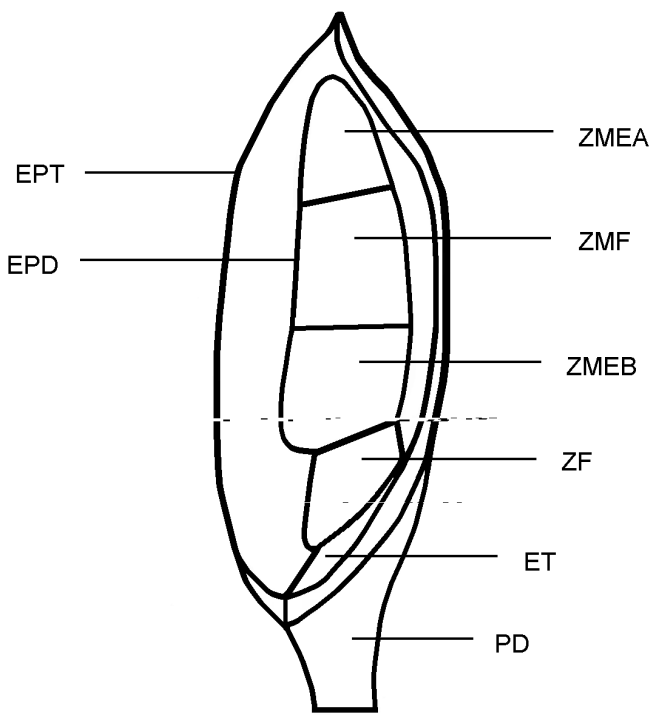

c

Figura 3 - Esquema foliar, caulinar e da inflorescência das espécies do gênero Philodendron ocorrentes na Reserva Ecológica de Macaé de Cima a. Esquema foliar - DA - divisão anterior; NLP - nervura lateral primária; NP - nervura principal; NA - nervura acroscópica; DP - divisão posterior; NB - nervura basioscópica; PE - pecíolo, BA - bainha; b. Arquitetura do sistema caulinar no subgênero Pteromischum - EPT - espata; EPD - espádice; LFR - lâmina foliar com bainha reduzida; PR - profilo; PRV - principal ramo vegetativo; LFL - lâmina foliar com bainha longa; c. Esquema da inflorescência - EPT - espata; EPD - espádice; ZMEA - zona masculina estéril apical; ZMF - zona masculina fértil; ZMEB - zona masculina estéril basal; ZF - zona feminina; ET - estípite; PD - pedúnculo

favorecidos por muitas orquídeas e bromélias, na zona mais exposta do dossel.

Os subgêneros Philodendron e Pteromischum devem ter se desenvolvido, principalmente, como plantas de florestas. Isto parece particularmente apropriado no caso do Rodriguésia 51(78/79): 21-68. 2000 subgênero Pteromischum, que, por causa de suas características morfológicas de ramos monopodiais é, talvez, o mais completamente dependente no habitat de mata úmida, e pode ser considerado como altamente especializado. 


\section{Tratamento Taxonômico}

\subsection{Descrição do Gênero}

Philodendron Schott

Schott in Wiener Zeitschr. Kunst, Lit., Theater und Mode 3: 780 (1829), nom. et orth. cons. ("Philodendrum"). Tipo: Philodendron grandifolium (Jacq.) Schott (Arum grandifolium Jacq.) lectotipificado por Britton et Wilson (1923).

= Baursea [Hoffmannsegg, Verzz. Pfl. 42. 1824, nom. nud.]; Post et Kuntze, Lexicon gen. phanerog. 62 (1903), nom. illegit. Tipo: Caladium bauersia Reichenbach, Icon. bot. exot. 2: 24, t. 160 (1829).

= Caladium subgênero Baursea Reichenbach, Consp. regn. veg. 44. 1828, nom. nud.]

= Bauersea Sterler, Hortus nymphenburgensis seu enumeratio plantarum in horto regio nymphenburgensi cultarum, ed. 2, 52. 1826, nom. nud.]

= Telipodus Raf., Fl. Tellur. 3: 66. 1836. Tipo: Arum grandifolium Jacq.

$=$ Thaumatophyllum Schott in Bonplandia 7(3): 31. 1859, et Prodr. Syst. Aroid. 581. 1860; Engler in Martius, Fl. bras. 3(2): 215.1878 et in A. et C. De Candolle, Monogr. Phanerog. 2: 636. 1879 et in Engler et Prantl, Naturl. Pflanzenfam. II. 3 :135. 1887; Hooker in Bentham et Hooker, Gen. Pl. 3(2): 979. 1883; Krause in Engler, Das Pflanzenreich 60: 137. 1913; Mayo et Barroso in Aroideana 2(3): 91. 1979. Tipo: Thaumatophyllum spruceanum Schott (1859)

= Elopium Schott in Oest. bot. Zeitschr. 15: 34. 1865. Tipo: Elopium surinamense (Miq.) Schott, baseado em Anthurium surinamense Miq.

Ervas pequenas a gigantes, hemiepifíticas escandentes, arborescentes ou rosuladas e acaulescentes, com caule trepador ou rastejante a rizomatoso, internó geralmente longo, as vezes muito curto, as vezes produzindo ramos flageliformes, escamas intravaginais presentes. Folhas numerosas, pequenas a gigantes, profilos de caules maduros marcescentes e decíduos ou persistentes e membranáceos ou decompostos até uma rede fibrosa. Pecíolo algumas vezes verrucoso ou coberto com protuberâncias do tipo escamas, as vezes geniculado no ápice; bainha longa com lígula curta em folhas monopodiais de todos os subgêneros e em folhas simpodiais do subgên. Pteromischum, mas em folhas simpodiais dos subgên. Philodendron e Meconostigma muito curta e inconspícua. Lâmina com formas muito variadas; inteira e linear, cordada, sagitada ou hastada, ou trilobada, trifida, trisecta, pinatilobada, pinatifida, bipinatifida, raramente pedatisecta; nervuras laterais primárias pinadas, raramente pedadas, fundindo-se na margem para formar uma nervura marginal, nervuras laterais secundárias e mais finas geralmente estritamente paralelas as primárias, as vezes terciárias e mais finas transversalmente reticuladas entre as secundárias, algumas vezes todas as nervuras são finas sem laterais primárias diferenciadas. Ramos floridos unidade simpodial de três principais padrões: - Subgên. Pteromischum: profilo, muitas folhas normais, $1(-2)$ inflorescência; subgên. Philodendron: hipopódio alongado, profilo, internó seguinte suprimido, 1 folha normal, 1-11 inflorescências; subgên. Meconostigma: hipopódio suprimido, profilo, internó seguinte desenvolvido ou muito curto, 1 folha normal, 1 (-2) inflorescência; Inflorescência 1-11 em cada simpódio floral, secretando resina na antese, ou da espata ou do espádice, raramente de ambos. Pedúnculo geralmente muito mais curto que o pecíolo. Espata ereta, inteiramente persistente, decídua somente no amadurecimento dos frutos (muito raramente caduca após a antese), espessa, as vezes extremamente grossa, geralmente constricta entre o tubo e a lâmina; tubo convoluto, cilíndrico à distendido, freqüentemente de coloração púrpura ou vermelho internamente; lâmina geralmente cimbiforme, amplamente aberta na antese, envolvendo posteriormente o espádice, geralmente branca por dentro. Espádice séssil à estipitado; zona feminina livre, raramente 
Philodendron Schott (Araceae): morfologia e taxonomia das espécies da Reserva Ecológica de

basalmente adnata a espata, geralmente mais curta do que a zona masculina fértil e separada desta pela zona masculina estéril; zona masculina estéril cilíndrica ou constricta ou elipsoidal, geralmente mais grossa e mais curta do que a zona masculina fértil, as vezes mais longa (subgên. Meconostigma); zona masculina fértil geralmente cilíndrica ou levemente elipsoidal, branca, geralmente fértil até o ápice do espádice, ou as vezes com um apêndice estaminodial apical. Flores unissexuais, perigônio ausente. Flores masculinas com estames 2-6, livres, prismáticos a obpiramidais, às vezes muito alongados e finos (subgên. Meconostigma), anteras sésseis à subssésseis, teca elipsóide à oblonga, alongada, deiscência por uma curta fenda lateral ou por poro subapical, conectivo espessado, truncado apicalmente e ultrapassando as tecas. Pólen expelido em filamentos ou misturado com resina secretada no eixo do espádice, ou exudado em massas amorfas, inaperturado, elipsóide à oblongo ou ocasionalmente alongado, na maioria das vezes perfeitamente psilato, as vezes de minuciosamente verruculado, áspero ou fossulado a evidentemente punctado, subfossulado, subfoveolado, raramente densamente e grosseiramente verrugado. Flores femininas com gineceu ovóide, subcilíndrico, cilíndrico ou obovóide, ovário
(2-) 4-8 (-47) - locular, óvulos 1-50 por lóculo, geralmente hemi-ortótropo, raramente hemianátropo, funículos longos a muito curtos com ou sem tricomas, placentação axilar ou subbasal à basal, região estilar geralmente tão larga quanto o ovário, as vezes levemente mais larga, as vezes atenuada, raramente alongada, lobada no subgên. Meconostigma, estigma as vezes também lobado, discóide hemi-esférico, freqüentemente tão largo quanto a região estilar. Bagas subcilíndricas à obovóides, 1 a muitas sementes, brancas, translúcidas esbranquiçadas, vermelhas, vermelhoalaranjadas. Semente minúscula a relativamente grande, ovóide-oblonga à elipsóide, raramente arilada, testa grossa, costada, raramente sarcotestada, embrião axilar, retilíneo, alongado, endosperma abundante.

\subsection{Relações Infragenéricas}

O gênero Philodendron Schott está, atualmente, subdividido em três subgêneros, dez seções e onze subseções, com aproximadamente 400 espécies (Mayo, 1990a). Esta classificação foi elaborada a partir da classificação de Krause (1913), tendo por base características como forma da folha, comprimento da bainha, hábito e comprimento da zona estaminodial entre a zona masculina e a zona feminina, forma dos estames e a estrutura do gineceu.

\subsubsection{Chave para a identificação dos subgêneros de Philodendron Schott}

1. Ramos florescentes maduros consistindo de uma sucessão de muitas folhas com longas bainhas peciolares, terminando por inflorescências solitárias ou, raramente, várias subgên. Pteromischum.

1'. Ramos florescentes maduros consistindo de uma sucessão de curtos artículos simpodiais, cada um suportando um profilo bicarenado sem lâmina e uma folha com uma curta ou muito reduzida bainha foliar; inflorescências solitárias a numerosas.

2. Zona estaminodial entre a zona masculina fértil e zona feminina do espádice sempre muito mais curta do que a zona masculina fértil; estames menos que 3 vezes mais longos que largos subgên. Philodendron.

2'. Zona estaminodial entre a zona masculina fértil e zona feminina do espádice quase igual ou mais longa que a zona masculina fértil; estames geralmente muito finos, ao menos 3 vezes mais longos que largos. .subgên. Meconostigma. 
5.2.2. O gênero Philodendron Schott na Reserva Ecológica de Macaé de Cima

- O gênero Philodendron está representado na Reserva Ecológica de Macaé de Cima, por 10 espécies situadas nos subgêneros Pteromischum e Philodendron, como mostra a tabela 2.

Tabela 2 - Distribuição das espécies de Philodendron Schott, ocorrentes na Reserva Ecológica de Macaé de Cima, dentro dos subgêneros e seções representados.

\section{Subgên. Philodendron}

\begin{tabular}{|l|}
\hline Seção Baursia \\
\hline P. edmundoi \\
\hline
\end{tabular}

\begin{tabular}{|l|}
\hline \multicolumn{1}{|c|}{ Seção Calostigma } \\
\hline$P$. altomacaense \\
\hline$P$. appendiculatum \\
\hline$P$. eximium \\
\hline$P$. fragile \\
\hline$P$. hatschbachii \\
\hline$P$. roseopetiolatum \\
\hline
\end{tabular}

\begin{tabular}{|l|}
\hline Seção Philodendron \\
\hline P. ornatum \\
\hline
\end{tabular}

Subgên. Pteromischum

\begin{tabular}{|l|}
\hline P. ochrostemon \\
\hline P. propinquum \\
\hline
\end{tabular}

5.3. Chave para identificação das espécies de Philodendron na Reserva Ecológica de Macaé de Cima, Rio de Janeiro.

1. Lâmina foliar elíptico-cordada a ovado-cordada a ovado-triangular e sagitada.

2. Lâmina foliar elíptico-cordada a ovado-cordada.

3. Planta de hábito hemi-epífito; lâmina ovado-cordada; tubo da espata creme internamente; placentação dos óvulos axilar.

4. Pecíolo com a presença de verrugas; até 2 inflorescências no simpódio floral; profilo persistente formando uma massa fibrosa e sem a presença de zona masculina estéril apical no espádice 8. P. ornatum. 4'. Pecíolo sem a presença de verrugas; de 3-5 inflorescências no simpódio floral; profilo não persistente e nem formando massa fibrosa; presença de zona masculina estéril apical no espádice 4. P. eximium. 3'. Planta de hábito hemi-epífito a terrestre; lamina foliar elíptico-cordada; tubo da espata carmim internamente; placentação dos óvulos sub-basal 1. P. altomacaense. 2'. Lâmina foliar ovado-triangular ou sagitada.

5. Lâmina foliar ovado-triangular; simpódio floral com até, raramente, 2 inflorescências; ausência de zona masculina estéril apical; presença de tricomas nos funículos dos óvulos .... .5. P. fragile. 5'. Lâmina foliar sagitada; simpódio floral com até 3 inflorescências; presença da zona masculina estéril apical; ausência de tricomas nos funículos dos óvulos. 
PhilodendronSchott (Araceae): morfologia e taxonomia das espécies da Reserva Ecológica de Macaé de Cima - Nova Friburgo, Rio de Janeiro, Brasil

6. Espata externamente verde-esbranquiçada à branca e internamente branca com forte constrição mediana 2. P. appendiculatum. 6'. Espata externamente verde claro à escuro à levemente rosado e internamente branca com base carmim, sem constrição mediana 10. P. roseopetiolatum. 1'. Lâmina foliar estreitamente elíptica, lanceolada à oblongo-lanceolada, oblongo-elíptica a ovado-oblonga.

7. Lâmina oblongo-elíptica a ovado-oblonga; número de lóculos 10-12 com 4 óvulos por lóculo e placentação sub-basal

6. P. hatschbachii.

7'. Lâmina foliar estreitamente elíptica, lanceolada, oblongo-lanceolada; número de lóculos 37 com 14 a numerosos óvulos por lóculo e placentação axilar.

8. Lâmina foliar sem nervuras laterais primárias diferenciadas, bainha menor que o pecíolo, estreitamente elíptica a oblongo-lanceolada; presença de nectários extraflorais vinosos no pecíolo; base interna da espata carmim 3. P. edmundoi. 8'. Lâmina com 5-9 pares de nervuras laterais primárias, bainha do mesmo comprimento do pecíolo, de estreitamente lanceolada a ovado-oblonga; ausência de nectários extraflorais vinosos no pecíolo; base interna da espata esbranquiçada.

9. Bainha foliar alada e aberta 9. P. propinquum.

9'. Bainha foliar alada e fechada com margens eretas até curvadas 7.P. ochrostemon.

\subsection{Descrição das espécies}

5.4.1. Philodendron altomacaense Nadruz \& Mayo, Bolm. Botânica Univ. São Paulo 17: 48. 1998. Typus: Brasil, Rio de Janeiro, Nova Friburgo, Macaé de Cima, Sítio Sophronitis, estrada principal., M. Nadruz 779 et al., 03.XI.92 (holotypus RB, isotypus K). Figs. 4,5 e 6.

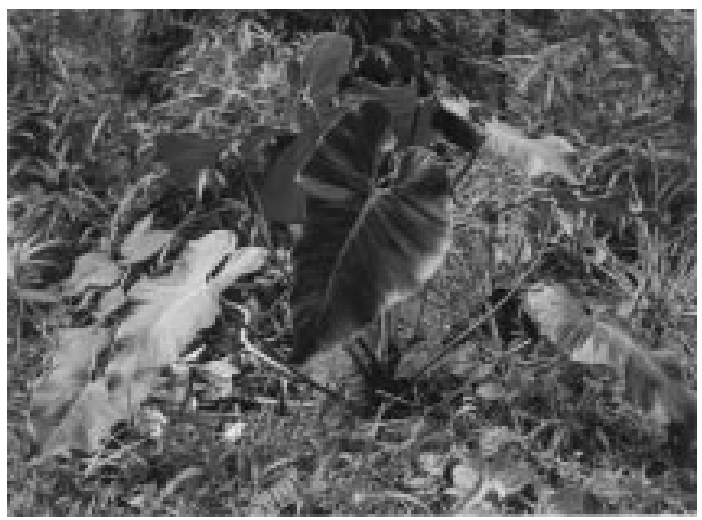

Figura 4 - Philodendron altomacaense Nadruz \& MayoHábito

Caule cilíndrico, $4.0-7.0 \mathrm{~cm}$ diâm., verde quando jovem, tornando-se castanho posteriormente. Internós (1-) 4.0-5.0cm compr. Raízes adventícias novas vermelhas, de ápice amarelado, as mais velhas com $6.0 \mathrm{~mm}$ diâm. Profilo ca. $30 \mathrm{~cm}$ compr., $1.5 \mathrm{~cm}$ larg., carnoso,

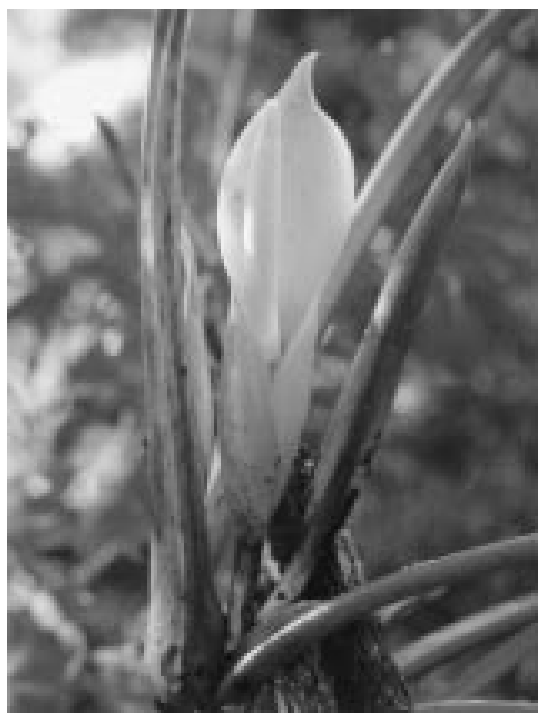

Figura 5 - Philodendron altomacaense Nadruz \& Mayo - Detalhe da inflorescência

avermelhado, tornando-se castanho posteriormente, caduco, pronunciadamente bicarenado. Pecíolo achatado na face adaxial com as margens levemente carenadas, 48.0$69.5 \mathrm{~cm}$ compr., $1.7 \mathrm{~cm}$ diâm., verde na porção médio proximal e avermelhado no ápice, opaco, estrias concolores a levemente mais escuras. Bainha verde $5.0 \mathrm{~cm}$ compr., em unidade simpodial adulta em flor. Lâmina cartácea, elíptico-cordada, (37.0-)45.0-47.5cm compr., (20.0-)26.0-27.0(-34.0)cm larg., verde escura 
brilhante na face adaxial e opaca na face abaxial, margem inteira, verde-amarelada ou arroxeada. Divisão anterior $26.5-37.0 \mathrm{~cm}$ compr., 16.0-24.5(-31.0)cm larg., ápice agudo e levemente cuspidado. Nervura principal impressa na face adaxial e saliente na face abaxial, verde, sendo mais clara que a lâmina na face adaxial e de verde-avermelhada a vermelha na face abaxial. Nervuras laterais primárias 6-7(-9) pares, impressas na face adaxial e salientes na face abaxial, concolores a mais claras que a lâmina ou verdeavermelhadas e opacas na face abaxial, freqüentemente com nuanças vermelhas. Nervuras interprimárias impressas na face adaxial e bem desenvolvidas na face abaxial. Divisão posterior (8.0-)12.0-18.0cm compr., (14.2-)18.0-29.0(-36.4)cm larg., lobos retrorsos, superpostos ou quase, denudação $2.0-3.5 \mathrm{~cm}$ compr., nervuras primárias acroscópicas 0-1(2) e primárias basioscópicas 2-3. Sinus parabólico-espatulado. Simpódio floral com até 3 inflorescências. Pedúnculo $4.5 \mathrm{~cm}$ compr., $1.1-1.2 \mathrm{~cm}$ diâm. no ápice, verde, tornando-se carmim no ápice. Espata 12.0$19.0 \mathrm{~cm}$ compr., $1.6-2.3 \mathrm{~cm}$ larg. na porção mediana, sem diferenciação entre tubo e lâmina, cilíndrica, cuspidada no ápice, decorrência de $4.5-5.3 \mathrm{~cm}$ compr., externamente creme-esverdeada a verdeavermelhada com faixa avermelhada no dorso da base até quase o ápice, internamente creme com a metade inferior carmim, com pontos mais claros. Espádice 13.0-17.0cm compr., séssil, com canais de resina ferrugínea no eixo abaixo das flores estaminadas; zona estaminada estéril apical creme, $0.8-0.9 \mathrm{~cm}$ compr., $0.6 \mathrm{~cm}$ diâm., zona estaminada fértil creme, $6.0-7.9 \mathrm{~cm}$ compr., $1.5 \mathrm{~cm}$ diâm., zona estaminada estéril basal creme, $1.3-1.5 \mathrm{~cm}$ compr., $1.5 \mathrm{~cm}$ diâm., zona pistilada verde, 5.8-6.8cm compr., $1.6 \mathrm{~cm}$ larg., conspicuamente adnada a espata por $4.3 \mathrm{~cm}$ compr. Estames 4-5, 2.0-2.5mm compr., 1.2-1.8mm larg. no ápice, levemente atenuados em direção à base. Estaminódios ca. $2.0 \mathrm{~mm}$ compr., $2.0-2.5 \mathrm{~mm}$ larg. no ápice, atenuados em direção à base.
Gineceu 4.5mm compr., 1.8mm larg. na região mediana, oblongo-obovado, ovário branco, lóculos (7-)8-10, óvulos 2-3 por lóculo, $0.7 \mathrm{~mm}$ compr., placentação sub-basal, com tricomas nos funículos. Infrutescência madura 8.8$10.0 \mathrm{~cm}$ compr., $1.7-2.2 \mathrm{~cm}$ diâm., bagas cilíndrico-obovais, esverdeadas a creme, 0.6$0.7 \mathrm{~cm}$ compr., $0.35-0.40 \mathrm{~cm}$ larg., estigma persistente; sementes esverdeadas numerosas, agrupadas aos pares, cilíndrico-elipsóides, ca. $1.5 \mathrm{~mm}$ compr., $0.8 \mathrm{~mm}$ larg.

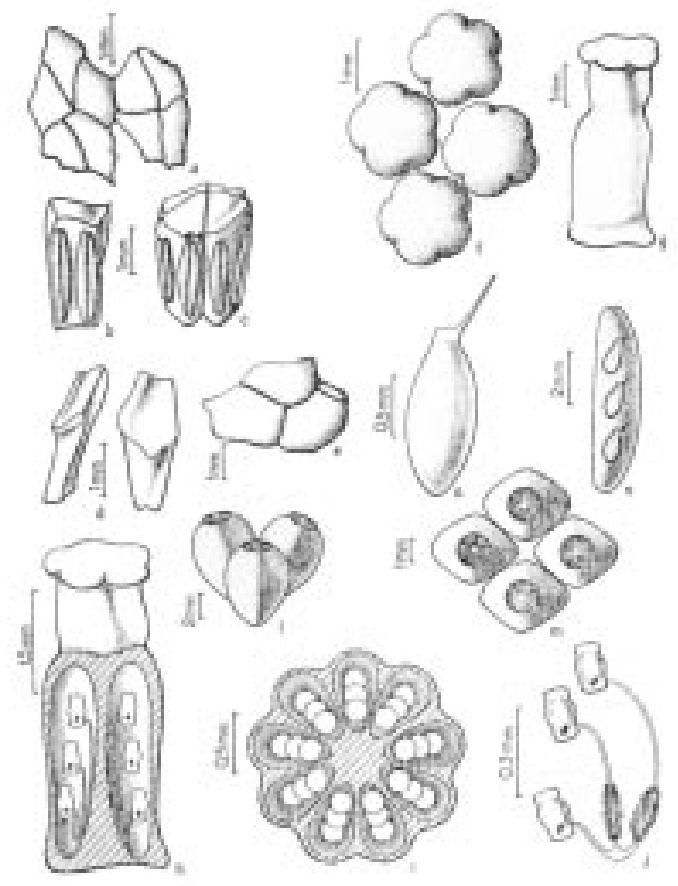

Figura 6 - Philodendron altomacaense Nadruz \& Mayo - a. Flores masculinas férteis, em vista apical, com 4-6 estames; $\mathbf{b}$. Detalhe do estame em vista frontal; $\mathbf{c}$. Detalhe da flor masculina em vista frontal; d. Detalhe dos estaminódios basais em vista frontal; e. Flor masculina estéril basal em vista apical; f. Flores femininas em vista apical; $\mathbf{g}$. Detalhe do gineceu em vista frontal; $\mathbf{h}$. Detalhe do gineceu em seção longitudinal mostrando lóculos com óvulos; i. Detalhe do gineceu em seção transversal mostrando lóculos com óvulos; j. Detalhe dos óvulos com a presença de tricomas nos funículos; l. Bagas em vista frontal; m. Bagas em vista apical; n. Conteúdo de um lóculo de um fruto maduro: sementes envolvidas com material gelatinoso; o. Detalhe da semente (Nadruz 779, 539). 
Philodendron Schott (Araceae): morfologia e taxonomia das espécies da Reserva Ecológica de Macaé de Cima - Nova Friburgo, Rio de Janeiro, Brasil

Material examinado: Brasil, Rio de Janeiro, Nova Friburgo, Distrito de Macaé de Cima: Sítio Sophronites, área do Projeto Mata Atlântica, 07.III.89, Nadruz et al. 481 (Paratypus - RB); Picada da Pedra Bicuda, 28.XII.89 Nadruz et al. 539 (Paratypus RB); Estrada do Hotel Fazenda São João, 02.XI.92, Nadruz et al. 757 (Paratypus - RB, $\mathrm{K})$; Estrada principal do Sítio Sophronites, 27.XII.93, Nadruz et al. 979 (Paratypus RB); Fazenda Ouro Verde, mata secundária, 25.VI.93, Vieira et al. 287 (Paratypus - RB).

Hemi-epífita escandente a terrestre rastejante, encontrada em floresta pluvial atlântica montana em local bastante úmido e sombreado, em altitude acima dos $1000 \mathrm{~m}$. Espécie freqüente na área e, até o momento, endêmica da região de Macaé de Cima. Possui grande valor ornamental devido à coloração e brilho de suas grandes folhas. Caracterizase, entre outros aspectos, pelo grande número de nervuras laterais primárias e interprimárias.

Espécie muito próxima de $P$. apparicioi Barroso, diferindo desta por apresentar pecíolo e espata não maculados, margem da lâmina foliar inteira, com 6-7 (-9) nervuras laterais primárias enquanto que $5 \mathrm{em} P$. apparicioi (Barroso 1957), zona estéril apical no espádice e número menor de lóculos no ovário.

Conforme os critérios da IUCN, a espécie é considerada em perigo; apesar de encontrar-se em unidade de conservação, acha-se mal protegida e ocorre em área restrita.

\subsubsection{Philodendron appendiculatum}

Nadruz \& Mayo, Bolm. Botânica Univ. São Paulo 17: 50. 1998. Typus: Brasil, Rio de Janeiro, Nova Friburgo, Macaé de Cima, Sítio Sophronites, estrada e picada, Nadruz et al. 780 , 03.XI.92 (Holotypus RB, Isotypus K); Figs. 7, 8 e 9.

Caule cilíndrico a levemente anguloso no ápice, $1.3-3.0 \mathrm{~cm}$ diâm., verde pouco brilhante no ápice, tornando-se verde acinzentado a cinéreo. Internós (1.3-)3.0-4.0(-6.0) cm comprimemnto. Raízes 3.0-4.0mm diâm., verde claras a amarelo esverdeadas tornandoRodriguésia 51(78/79): 21-68. 2000

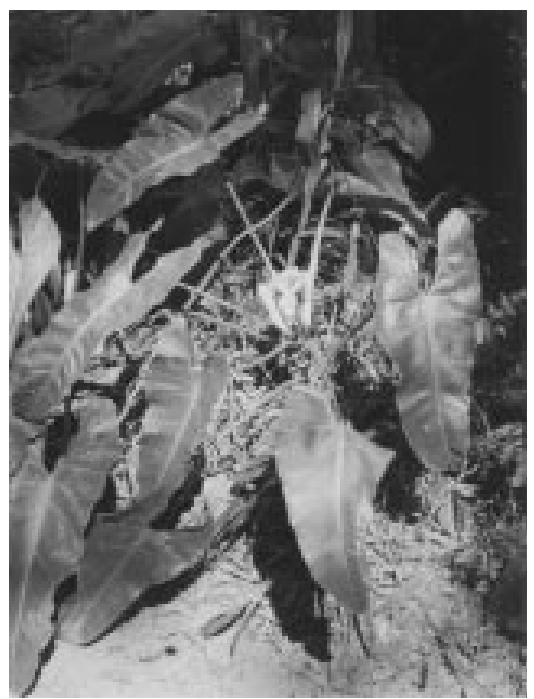

Figura 7 - Philodendron appendiculatum Nadruz \& Mayo - Hábito

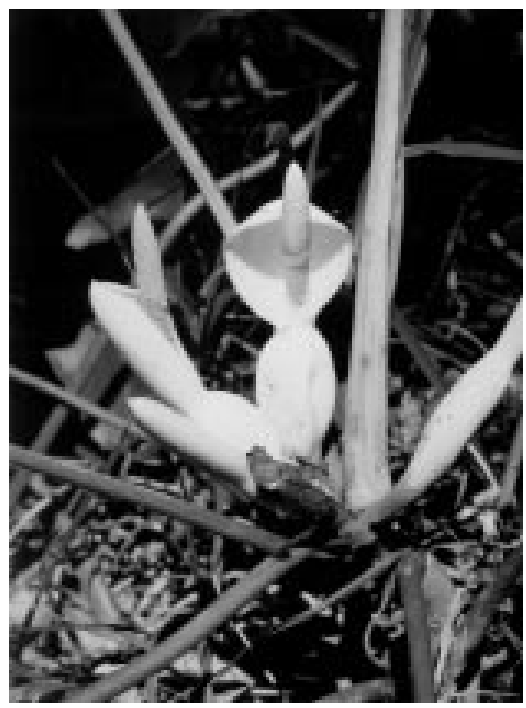

Figura 8 - Philodendron appendiculatum Nadruz \& Mayo - Detalhe da inflorescência

se castanho posteriormente claras. Profilo esverdeado quando novo tornando-se verde rosado a rosado com as carenas esverdeadas, $10.5-29.0 \mathrm{~cm}$ compr., $5.5 \mathrm{~cm}$ larg. na base. Pecíolo cilíndrico a levemente achatado na face adaxial, 32.5-39.5cm comp e 0.6-1.0cm diâm., verde com estrias longitudinais escuras, levemente lúcido. Bainha $3.0-5.5 \mathrm{~cm}$ compr., na unidade simpodial adulta em flor. Lâmina foliar jovem ovado-cordada $17.0-18.5 \mathrm{~cm}$ compr., 9.0- 
$12.0 \mathrm{~cm}$ larg., adulta sagitada, (24.0-)29.0$36.5 \mathrm{~cm}$ compr., (12.0-)14.0-18.7cm larg., cartácea, verde discolor, sendo mais clara na face abaxial e lúcida em ambos os lados, margem inteira podendo ser amarelada a rosada. Divisão anterior (17.5-) $20.5-27.0 \mathrm{~cm}$ compr., 10.4-15.5(-19.5)cm larg., ápice obtuso a levemente acuminado. Nervura principal concolor em ambos os lados. Nervuras laterais primárias 3-5 pares, impressas na face adaxial, salientes na face abaxial e concolores a mais claras em ambos as faces, com linhas glandulares na face abaxial. Nervuras interprimárias desenvolvidas. Divisão posterior com lobos retrorsos, (5.5-)7.2-11.5 cm compr., (12.0-)13.4-17.2 cm larg., nervuras acroscópicas 0-2 e nervuras basioscópicas 02. Sinus parabólico-espatulado. Simpódio floral com 2-3 inflorescências. Pedúnculo (2.5-)4.5$6.5 \mathrm{~cm}$ compr. e $0.9 \mathrm{~cm}$ diâm. no ápice, junção pedúnculo/espata verde escura e raramente arroxeada. Espata 10.0-11.5cm compr., externamente verde esbranquiçada a branca e internamente branca com pontos mais claros, pequenos e numerosos, pronunciadamente constricta com forte diferenciação entre lâmina e tubo, lâmina 5.0-6.8cm compr., $1.3 \mathrm{~cm}$ larg., tubo $4.4-4.8 \mathrm{~cm}$ compr., $1.2 \mathrm{~cm}$ larg. Espádice $8.5-11.5 \mathrm{~cm}$ compr., com canais de resina abaixo das flores masculinas, zona estaminada estéril apical branca, $3.5 \mathrm{~cm}$ compr., $1.0 \mathrm{~cm}$ diâm., zona estaminada fértil branca, $2.9 \mathrm{~cm}$ compr., $0.9 \mathrm{~cm}$ diâm., zona estaminada estéril basal branca, $1.7 \mathrm{~cm}$ compr., $0.5 \mathrm{~cm}$ diâm., zona pistilada verde, $3.3 \mathrm{~cm}$ compr. e $0.8 \mathrm{~cm}$ diâm. Estames 3-4(-6) por flor, com $1.0 \mathrm{~mm}$ compr., $0.8-1.0 \mathrm{~mm}$ larg. no ápice. Estaminódios apicais $1.3 \mathrm{~mm}$ compr., $1.0 \mathrm{~mm}$ larg. no ápice, basais 1.8-2.1 $\mathrm{mm}$ compr., $0.3-1.1 \mathrm{~mm}$ larg. no ápice. Gineceu $1.5 \mathrm{~mm}$ compr., $1.0 \mathrm{~mm}$ larg. no ápice, ovário branco, lóculos (7-)8-9, óvulos 0.6mm compr., 2-3(-4) por lóculo, inseridos na base do septo saindo de um mesmo ponto, região estilar intensamente verde e estigma discóide.
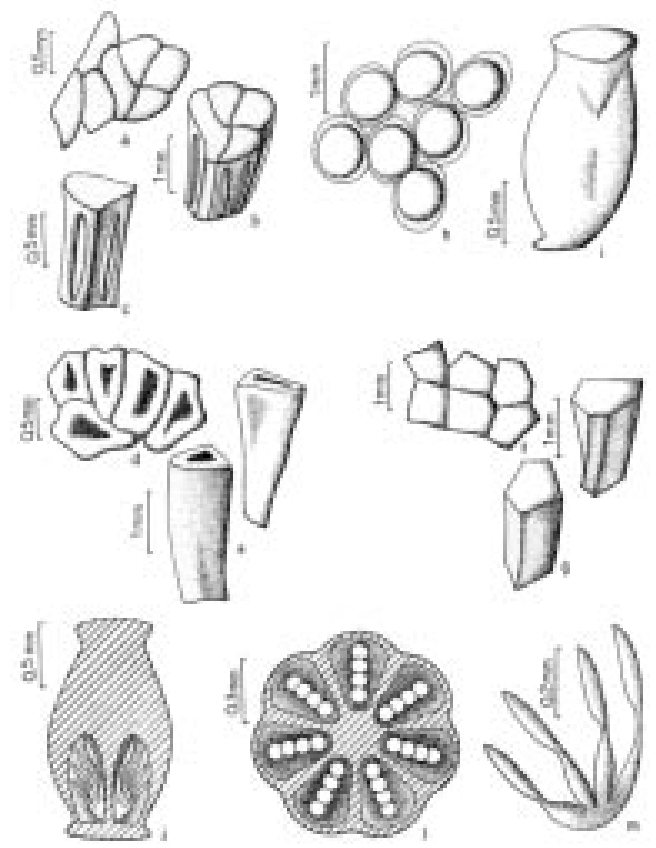

Figura 9 - Philodendron appendiculatum Nadruz \& Mayo - a. Flores masculinas férteis, em vista apical, com 4 estames; $\mathbf{b}$. Detalhe da flor masculina em vista frontal; c. Detalhe do estame em vista frontal; d. Flores masculinas estéreis basais em vista apical; e. Detalhe dos estaminódios basais em vista frontal; f. Flores Masculinas estéreis apicais em vista apical; g. Detalhe dos estaminódios apicais em vista frontal; $\mathbf{h}$. Flores femininas em vista apical; i.Detalhe do gineceu em vista frontal; $\mathbf{j}$. Detalhe do gineceu em corte longitudinal mostrando lóculos com óvulos. I. Detalhe do gineceu em corte transversal mostrando lóculos com óvulos; m. Detalhe dos óvulos (Nadruz 1065, 780, 758, 541).

Material examinado: Brasil, Rio de Janeiro, Nova Friburgo, Distrito de Macaé de Cima: Sítio Sophronites, área do Projeto Mata Atlântica., 07.III.89, Nadruz 481 et al (Paratypus - RB); Picada da Pedra Bicuda., 28.XII.89, Nadruz 541 et al (Paratypus RB); Estrada do Hotel Fazenda São João, 02.XI.92, Nadruz 758 et al (Paratypus - RB, $\mathrm{K})$; Estrada que leva até a entrada do Sítio Sophronites, 03.XI.92, Nadruz 773 et al (Paratypus - RB, K); Picada para a Pedra Bicuda, 23.III.94, Nadruz et al. 1003 (Paratypus - RB); Estrada entre hotel São João e o Sítio Fazenda Velha, na beira do Rio Macaé, 26.IX.94, 980m, Nadruz et al. 1065 (Paratypus - RB). 
Philodendron Schott (Araceae): morfologia e taxonomia das espécies da Reserva Ecológica de Macaé de Cima - Nova Friburgo, Rio de Janeiro, Brasil

Philodendron appendiculatum tem sua distribuição na região sudeste do Brasil e nos estados do Paraná e Santa Catarina (Mayo et al 1994). Espécie hemi-epífita, crescendo em local bastante úmido e sombreado, em floresta pluvial atlântica montana, acima de $1100 \mathrm{~m}$, sendo freqüente na área de Macaé de Cima.

Espécie muito próxima de $P$. inops da qual difere na forma da lâmina foliar, onde a divisão anterior não é alongada, e pelo maior comprimento do pecíolo em relação à lâmina, pela presença de um estrangulamento na porção mediana da inflorescência tanto no espádice quanto na espata, em $P$. inops espata e espádice cilíndricos (Schott, 1859) e por apresentar uma zona terminal estéril no espádice. O nome deriva do apêndice estéril terminal do espádice.

Conforme os critérios da IUCN, a espécie foi considerada protegida, tendo em vista sua extensa ocorrência comprovada por coleções botânicas.

5.4.3. Philodendron edmundoi G.M. Barroso in Arq. Jard. Bot. Rio de Janeiro, 15: 90, t. II. 1957; Engler in Martius Flora Brasiliensis III. 2:152. 1878; Krause in Engler, Das Pflanzenreich IV. 23. Db :60. 1913. TIPO: Brasil, Rio de Janeiro, Serra dos Órgãos, cult. Jard. Bot. Rio de Janeiro ${ }^{\circ}$ 6863, E. Pereira s/n (RB 97070 Holotypus); Figs. 10, 11 e 12.

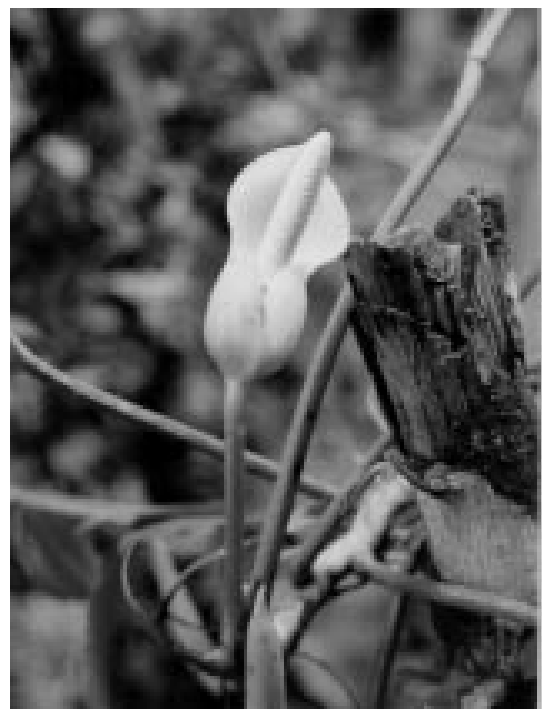

Figura 10 - Philodendron edmundoi G.M. Barroso Detalhe da inflorescência

Rodriguésia 51(78/79): 21-68. 2000

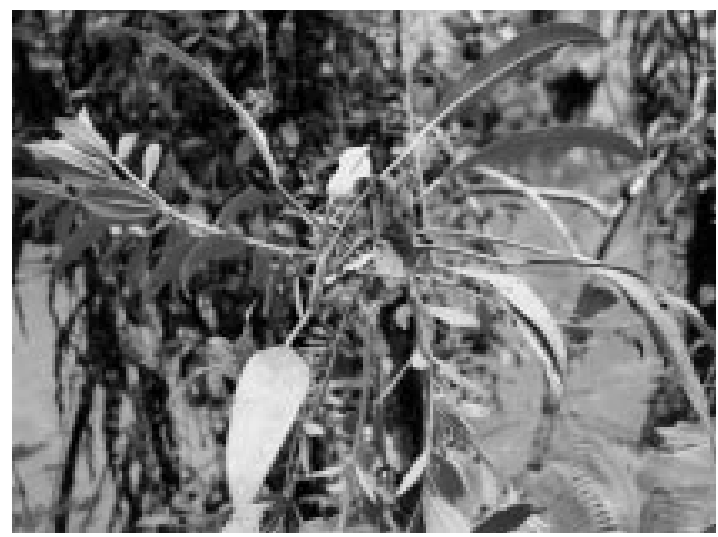

Figura 11 - Philodendron edmundoi G.M. Barroso Hábito

Caule cilíndrico, opaco, verde no ápice tornando-se de cor de palha a castanho, $2.0-2.5 \mathrm{~cm}$ diâm. Internós $2 \cdot 0-3.0 \mathrm{~cm}$ compr. Raízes adventícias $0.2-0.3 \mathrm{~cm}$ diâm., de castanho avermelhado a vermelhas, tornandose castanhas com o passar do tempo. Profilo (3.5-)15.3-20.0cm compr. e 4.0-5.0cm larg. na base, muito pouco persistente, verde quando novo com nuanças carmim, principalmente na base, e nectários esparsos carmim, tornandose cor de palha a castanho com o passar do tempo. Pecíolo esverdeado, opaco com nectários extraflorais vinosos, tornando-se arroxeado ou formando somente um distinto anel roxo na junção com lâmina, (28.0-)33.0$40.0 \mathrm{~cm}$ compr. e $0.5-0.6 \mathrm{~cm}$ diâm., esponjoso, aplanado na face superior e arredondado na inferior, com estrias mais escuras a arroxeadas sendo mais freqüente no ápice. Lâmina foliar levemente coriácea (27.0-)37.0-55.2cm compr. e (9.2-)10.5-11.0cm larg., estreitamente elíptica a oblongo-lanceolada, base de cuneada a arredondada, verde discolor quando jovem, face superior verde opaca a levemente lúcida e levemente rugosa conforme a nervação fina e na face inferior levemente glaucescente e opaca quando adulta. Nervura central levemente convexa na face superior, pronunciadamente proeminente na face inferior e mais clara que a lâmina em ambas as superfícies, as vezes concolor na face superior ou em ambas as faces e apresentando nectários extra florais em ambas as faces ou na inferior somente. Nervuras laterais 
primárias ausentes. Simpódio floral com uma única inflorescência. Pedúnculo (17.0-)21.5$23.5 \mathrm{~cm}$ compr. e $1.3 \mathrm{~cm}$ diâm., verde levemente lúcido com estrias mais escuras e pequenos nectários esparsos roxos a vinosos. Espata ereta $9.0-15.0 \mathrm{~cm}$ compr., verde externamente com pequenos nectários esparsos, tubo $4.5 \mathrm{~cm}$ compr. e $2.5 \mathrm{~cm}$ larg., carmim internamente, lâmina $10.0 \mathrm{~cm}$ compr. e $1.7 \mathrm{~cm}$ larg., de branca a verde-amarelada com pontos brancos internamente. Espádice 7.5-11.5(-14.5)cm compr., estípite $0.7 \mathrm{~cm}$ de compr., zona masculina fértil creme a alaranjada em condição pós-floral, $6.2-11.1 \mathrm{~cm}$ compr. e 1.2$1.4 \mathrm{~cm}$ diâm. na região mediana, presença de canais de resina amarelada abaixo dos estames, zona masculina estéril alba 1.5$2.7 \mathrm{~cm}$ compr. e $1.4-1.8 \mathrm{~cm}$ diâm., zona feminina $2.2-2.7 \mathrm{~cm}$ compr. e $1.5 \mathrm{~cm}$ diâm., verde claros (amarelados - Martinelli 12972 et al.) Estames 4-6 por flor, 2.0-3.0mm compr. e 1.5-2.5mm larg. no ápice. Estaminódios com canais de resina na base, $3.0-4.0 \mathrm{~mm}$ de compr. e 2.0-2.3mm larg. no ápice. Gineceu 1.0$3.0 \mathrm{~mm}$ compr. e $1.0-2.5 \mathrm{~mm}$ larg., ovário de branco a creme, lóculos 6-7(-8), óvulos 14 por lóculo em 2 fileiras paralelas, placentação axilar, estigmas lobados, número de lobos igual ao número de lóculos. Frutos jovens, $5.0 \mathrm{~mm}$ compr. e $4.0 \mathrm{~mm}$ larg., bagas verde no ápice e branca do meio para a base, estigma persistente ferrugíneo. Infrutescência $4.2 \mathrm{~cm}$ compr. e $2.0 \mathrm{~cm}$ diâm.

Material examinado: Rio de Janeiro, Nova Friburgo, Macaé de cima: Margens do Rio Macaé, 03.01.60, Pabst 5241(HB!); Nascente do Rio das Flores, mata atlântica, $1000 \mathrm{msm}$, 23.06.88, Martinelli 12972(RB); Picada para a Pedra Bicuda, 28.12.89, Nadruz 556; Sítio Sophronites, área da parcela, 23.03.92, Nadruz et al. 740(RB); Sítio Bacchus, picada atrás do alojamento, 02.11.92, Nadruz et al. 755(RB); Estrada que leva até a entrada do Sítio Sophronites, 03.11.92, Nadruz 776(RB,K); Sítio Sophronites, mata atlântica de encosta, 22.03.94, Nadruz et al. 993(RB); Idem, idem, 22.03.94, Nadruz et al. 994; Idem,
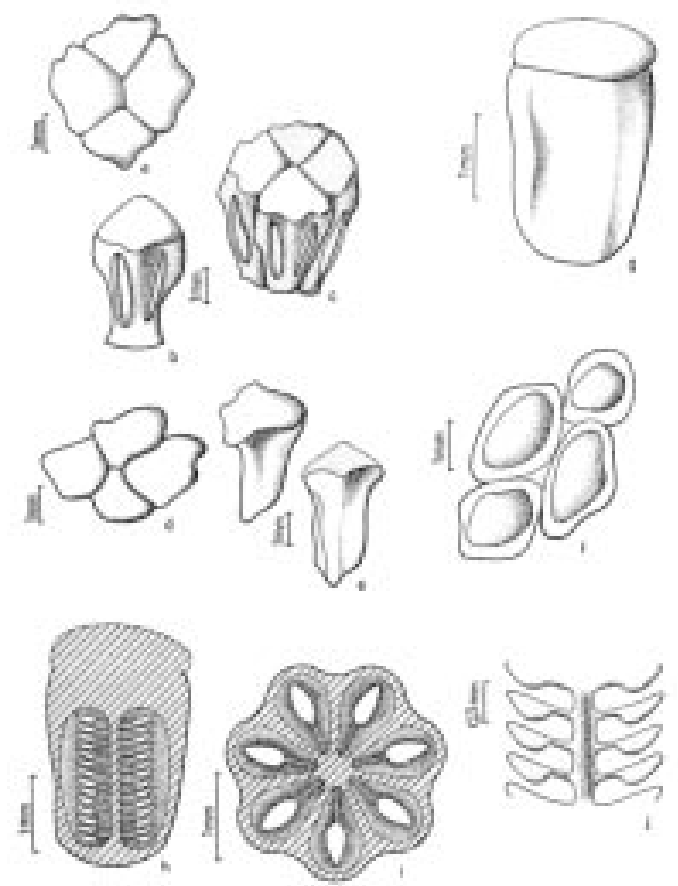

Figura 12 - Philodendron edmundoi (Nadruz 1013, 1005, $776,556)$ - a. Flores masculinas férteis, em vista apical, com 4 estames; b. Detalhe do estame em vista frontal; c. Detalhe da flor masculina em vista frontal; d. Flores masculinas estéreis em vista apical; e. Detalhe dos estaminódios em vista frontal; f. Flores femininas em vista apical; g. Detalhe do gineceu em vista frontal; $\mathbf{h}$. Detalhe do gineceu em corte longitudinal mostrando lóculos e óvulos; i. Detalhe do gineceu em corte transversal mostrando lóculos e óvulos; j. Detalhe dos óvulos.

idem, 22.03.94, Nadruz et al. 996(RB); Picada para a Pedra Bicuda, 23.03.94, Nadruz et al. 1005(RB); Idem, idem, 23.03.94, Nadruz et al. 1006(RB); Estrada principal que corta a Reserva, entre o Hotel São João e o sítio do João Luís, beirando o Rio Macaé, 19.04.94, Nadruz 1013(RB); Estrada do Cassino, 10.11.94, Nadruz et al. 1078(RB); Caminho para a nascente do Rio Macaé, depois da entrada para o sítio do João Luís, 17.01.91, Pessoa et al. 558(RB); Sítio Sophronites, trilha para a parcela 1, 28.10.90, Sylvestre et al. 381(RB); Estrada que leva a Lumiar, Vieira et al. 415; Teresópolis, Cultivada no Jardim Botânico do Rio de Janeiro sob o $n^{\circ} 6863, \mathrm{~s} / \mathrm{d}$, Pereira s/n (RB: 97070, Holotypus).

Espécie conhecida vulgarmente por 
Philodendron Schott (Araceae): morfologia e taxonomia das espécies da Reserva Ecológica de

“imbirana”. Tem a sua distribuição geográfica nos estados do Espírito Santo e Rio de Janeiro. Possui o hábito hemi-epifítico podendo crescer também em rochas expostas. Encontrada em mata atlântica de encosta em locais bastante úmidos e sombrios até ensolarados, podendo chegar à $1400 \mathrm{msm}$. Espécie freqüente na área em estudo.

Espécie muito próxima a $P$. longilaminatum, $P$. crassinervium e $P$. glaziovii, todas pertencentes ao subgênero Philodendron seção Baursia, a qual se caracteriza pela ausência de nervuras laterais primárias, presença de lóbulos estigmáticos, placentação axilar e óvulos numerosos. P. longilaminatum é conhecida apenas na região de mata atlântica dos estados da Bahia e Pernambuco, possuindo o pecíolo estreitamente sulcado na face superior, ocorrendo em restingas e matas úmidas com altitudes de até $200 \mathrm{msm}$, enquanto que em $P$. edmundoi o pecíolo encontra-se aplanado na face superior e sua ocorrência está acima dos $800 \mathrm{msm}$. Difere de P. crassinervium por possuir nervura central muito menos robusta, folhas mais longas e mais largas e pecíolo mais longo, e de $P$. glaziovii difere pela ausência da zona estéril masculina no (ápice do) espádice, pelo maior número de óvulos dispostos bisseriados em toda a extensão dos lóculos e pelo maior comprimento do pedúnculo.

De acordo com os critérios de conservação da natureza, a espécie é considerada em perigo já que apesar de ter sido encontrada na natureza nos últimos 50 anos ocorre em área restrita.

5.4.4. Philodendron eximium Schott in Oesterr. bot. Wochembl. 3(48): 378. 1853; Vellozo Fl. Flumin. 9: t. 112. 1831; C. Koch et Sauer in Index Sem. Hort. Berol. 8. 1854; Schott, Ic. Aroid., 40 plates, tt. I-V. 1857a et Prodr. Syst. Aroid. 251-252; 1860. Krause in Engler, Das Pflanzenreich 60 (IV, $23 \mathrm{Db}): 80$. 1913. TIPO: "Schott Icones Aroidearum" $n^{\circ}$ 2486 (lectotypus W!). Figs.13, 14 e 15.
= Arum amphibium Vellozo [Fl. Flumin. 9: t. 112. 1831 (1827), nom. nud., sem análise na figura.]; in Arch. Mus. Nac. Rio de Janeiro $5: 387,1881$.

= Philodendron amphibium (Vellozo)

Kunth ex Stellfeld, in Arq. Mus. Paranaense 8:185. 1950.

$=P$. eximium Schott in Oest. bot. Wochenbl. 3: 378. 1853. TIPO: "Brasilia S. v.v. spont. et cult." ???

$=P$. cardiophyllum C.Koch et Sello in Index Sem. Hort. Berol. app. 4. 1853. TIPO: Provavelmente uma planta cultivada no Jardim Botânico de Berlim. "...ex America tropica sine dubio allatam".

$=P$. eximium $\mathrm{C}$. Koch et Sauer in loc. cit. 8. 1854. TIPO: Provavelmente uma planta cultivada no Jardim Botânico de Berlim. Não existe exsicata nem localidade citada.

$=P$. saueranum $\mathrm{C}$. Koch in loc. cit. 3 . 1855. TIPO: Provavelmente uma planta cultivada no Jardim Botânico de Berlim. Localidade não citada.

= Philodendron eximium var. cardiophyllum (C. Koch \& Sello) Engler in Engler's Bot. Jahrb. 26 :536. 1899. TIPO: "Brasilia: prov. Rio de Janeiro, ad rupes regiones Floresta dictae in monte Tijuca (Ule. - Florif. m. Nov. 1896)."

Caule verde quando jovem tornando-se cor de palha, levemente aplanado em uma das faces, opaco $4.0-5.6 \mathrm{~cm}$ diâm. Internós $1.0 \mathrm{~cm}$ de compr. sendo $4.0-5.6 \mathrm{~cm}$ compr. no ápice do caule. Raízes adventícias 0.3-7.0mm diâm., de castanha a castanho-ferrugíneas opacas. Profilo persistente $20.0-21.5 \mathrm{~cm}$ compr. e $2.8 \mathrm{~cm}$ larg. na base, verde esbranquiçado com estrias mais claras, levemente lúcido, carnoso, pronunciadamente bicarenado e alado. Pecíolo (22.0-)30.0-46.0cm compr. e $1.4 \mathrm{~cm}$ diâm. na região mediana, aplanado na face superior e arredondado na inferior, esverdeado com estrias pouco mais escuras a mais claras, levemente lúcido, sem nectários extraflorais. Bainha em unidade simpodial adulta florida $5.5-7.0 \mathrm{~cm}$ compr., involuta. Lâmina foliar ovado-cordada, ápice acuminado, 26.0-30.0(- 


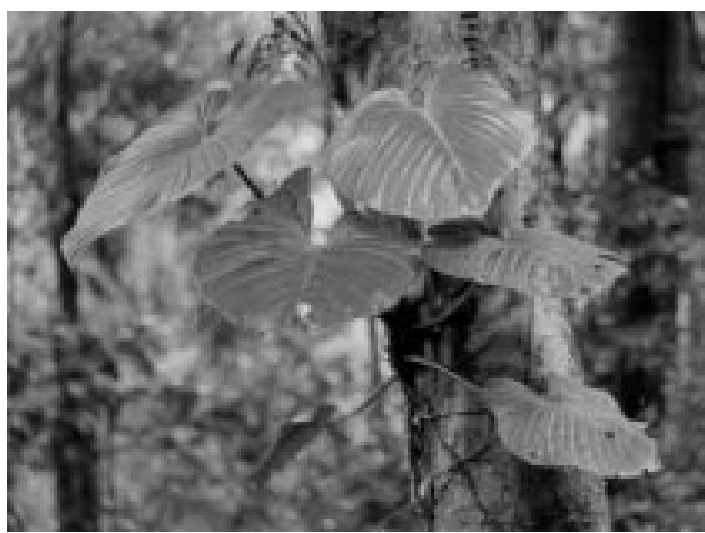

Figura 13 - Philodendron eximium Schott - Hábito

46.2) cm compr. e 19.0-22.0(-33.0)cm larg., verde lúcido na superfície inferior e opaco a levemente lúcida na superior, cartácea, margem inteira, presença de linhas glandulares na face inferior. Divisão anterior (17.5-)25.028.0(-32.8)cm compr. e (19.0-)28.0-29.0($37.0) \mathrm{cm}$ larg. Nervura principal um pouco mais clara que a lâmina na superfície superior, saliente e concolor na superfície inferior. Nervuras laterais primárias concolores em ambos os lados, 5-7 pares, patentes, impressas na face superior e salientes na inferior. Nervuras interprimárias bem evidentes. Divisão posterior com lobos não superpostos, retrorsos, arredondados, (6.5-)17.2-19.2(-24.0) cm compr. e 8.8-10.0(-28.0)cm larg., nervuras primárias acroscópicas 0-1 e basioscópicas 1-2. Sinus parabólicos. Simpódio floral com até 5 inflorescências. Pedúnculo (4.0-)8.5-10.5cm compr. e $1.1 \mathrm{~cm}$ de diâm., verde claro, apresentando estrias mais claras. Espata externamente verde-esbranquiçada, internamente branca com pontos mais claros, $16.2-24.0 \mathrm{~cm}$ compr., sem diferenciação de tubo e lâmina, em pré-antese parte basal $1.8 \mathrm{~cm}$ diâm. e parte apical $1.4 \mathrm{~cm}$ diâm., decorrência 3.0-4.8cm compr. Espádice estreitando-se para o ápice $19.2-23.0 \mathrm{~cm}$ compr., presença de glândulas de resina abaixo das flores das zonas masculinas estéril e fértil, zona masculina estéril apical esbranquiçada $1.5 \mathrm{~cm}$ compr. e $0.5 \mathrm{~cm}$ diâm., zona masculina fértil esbranquiçada, $12.5 \mathrm{~cm}$ de compr. e $1.1 \mathrm{~cm}$ diâm., zona masculina estéril basal esbranquiçada, $1.2 \mathrm{~cm}$
Coelho, M. A. N.

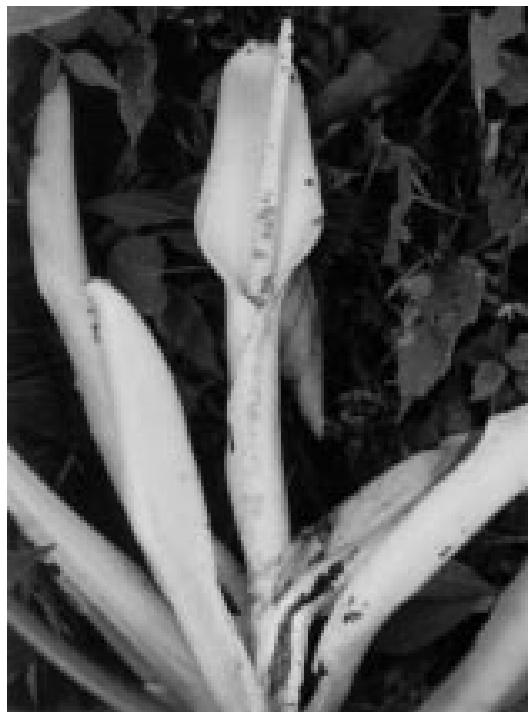

Figura 14 - Philodendron eximium Schott - Detalhe da inflorescência

compr. e $1.3 \mathrm{~cm}$ diâm., zona feminina verde claro $6.8 \mathrm{~cm}$ compr. e $1.2 \mathrm{~cm}$ diâm., área adnata da zona feminina com a espata $3.0-4.8 \mathrm{~cm}$ compr. Estames 3-5 por flor, 1.0-1.5mm compr. e 1.1-1.5mm larg. Estaminódios $1.6 \mathrm{~mm}$ compr. e $1.4 \mathrm{~mm}$ de larg. Gineceu $3.0 \mathrm{~mm}$ compr. e $2.0 \mathrm{~mm}$ larg., ovário albo, estilete verde, estigma globoso, lóculos 9-10, óvulos $0.7 \mathrm{~mm}$ de compr., 3-5 por lóculo, inseridos próximo a base do septo, presença de tricomas nos funículos.

Material examinado: Rio de janeiro, Nova Friburgo, Macaé de Cima: Remanescente de Floresta Pluvial Tropical Costeira, transição entre matas baixo e alto montanas, nascente do Rio das Flores, 1000-1100msm, 25.05.87, Martinelli et al. 12044 (RB), Estrada que leva até a entrada do Sítio Sophronites, 03.11.92, Nadruz et al. 777 (RB, K). Estrada principal que corta a Reserva, entre Hotel São João e sítio do João Luís, beirando o Rio Macaé, 19.04.94, Nadruz 1018, (RB); Estrada entre o hotel São João e o Sítio Fazenda Velha, na beira do Rio Macaé, 980msm, 29.09.94, Nadruz 1067 (RB);

Espécie conhecida vulgarmente pelo nome "imbé", distribui-se pelos estados de Pernambuco, Rio de Janeiro e São Paulo. No Rio de Janeiro é encontrada nas cidades do Rio de Janeiro, Nova Friburgo e Petrópolis. 


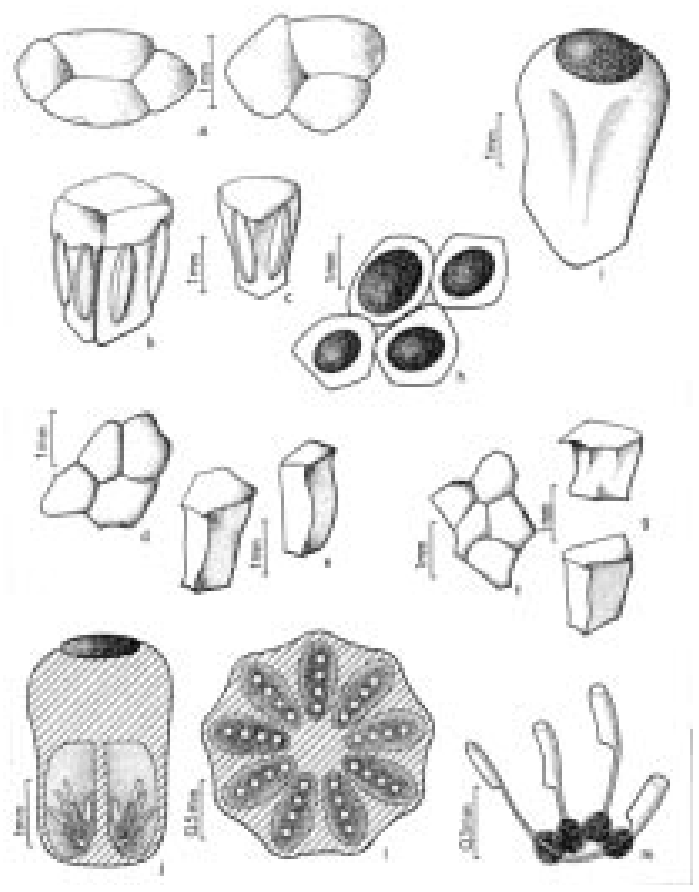

Figura 15 - Philodendron eximium Schott. (Nadruz 1067, 777, Martinelli 12044 et al) - a. Flores masculinas férteis, em vista apical, com 3-4 estames; b. Detalhe da flor masculina em vista frontal; $\mathbf{c}$. Detalhe do estame em vista frontal; d. Flores masculinas estéreis basais em vista apical; e. Detalhe dos estaminódios basais em vista frontal. f. Flores masculinas estéreis apicais em vista apical; g. Detalhe dos estaminódios apicais em vista frontal; $\mathbf{h}$. Flores femininas em vista apical; i. Detalhe do gineceu em vista frontal; $\mathbf{j}$. Detalhe do gineceu em corte longitudinal mostrando lóculos com óvulos; 1. Detalhe do gineceu em corte transversal mostrando lóculos com óvulos. $\mathbf{m}$ Detalhe dos óvulos com a presença de tricomas nos funículos.

Hemi-epífita, ocorrente em matas de brejo e floresta pluvial atlântica baixo montana e montana em local bastante úmido e sombreado. Pode chegar até $1100 \mathrm{~m} . \mathrm{s} . \mathrm{m}$. Pouco freqüente na região da Reserva Ecológica de Macaé de Cima.

Schott publicou P. eximium em 1853 citando como localidade Brasil ('Brasilia S. v.v. spont. et cult.") e, no mesmo ano, Koch et Sello publicaram $P$. cardiophyllum mencionando que esta espécie, sem dúvida nenhuma, viera da América Tropical indicando, ainda, a proximidade com $P$. punctatum. Em 1854 Koch publicou, novamente, o nome $P$. eximium colocando como localização a
América Tropical e comentou sua proximidade com $P$. cardiophyllum salientando o tamanho da folha como a única diferença entre ambos. Em 1855 Koch concordou com o erro que cometeu considerando o nome supérfluo $P$. eximium já publicado por Schott e mudando o nome da planta para $P$. saueranum. Porém, ele não comentou o fato de $P$. eximium Schott e $P$. saueranum Koch serem a mesma espécie. Em 1860 Schott cita P. eximium e ressalta $P$. saueranum como sinônimo e, cita também, P. cardiophyllum como espécie válida colocando $P$. macrophyllum (nomem nudum) como sinônimo deste. Em 1899 Engler cita $P$. eximium colocando $P$. saueranum como sinônimo, destacando ser esta um espécime jovem ("stirps juvencula"), e cria a variedade cardiophyllum.

O Ícone de Schott número $2666 \mathrm{da}$ espécie $P$. cardiophyllum é similar a $P$. eximium em relação a forma da folha.

Para o estabelecimento de $P$. eximium var. cardiophyllum, Engler destaca como característica a cor da espata "tornando-se verde". Esse caráter não é suficientemente forte para considerar um novo táxon, observando que a espata pode variar de cor dependendo do seu estágio de desenvolvimento.

Não foram observados os typus das espécies Philodendron saueranum e $P$. eximium, provavelmente destruídos durante a II Guerra Mundial, sendo que as conclusões para a sinonimização destas espécies com $P$. eximium foram baseadas nas comparações das descrições originais.

Segundo Vellozo, em sua curta descrição de Arum amphibium (apud Stellfeld, 1950), publicado na Flora Fluminensis com mais 24 espécies da família Araceae, a espécie é caulescente, radicante, com as folhas cordiformes, asas separadas, espata esbranquiçada e abraçando com suas raízes as árvores que encontra". Essas características, juntamente com a estampa que mostra a forma da folha com as nervuras primárias e secundárias se alternando e o 
número de inflorescências no simpódio floral (5), nos leva a crer que seja Philodendron eximium, este, segundo descrição de Schott (1853), apresenta os seguintes caracteres: "lamina rotundado-cordiforme undata", "venis frequentis subaproximatis", "inflorescentia plures" e "spathae lamina lanceolata, alba".

Tendo em vista que Vellozo publicou Arum amphibium em 1831 sem qualquer descrição, somente com a estampa, mas que a mesma não continha uma análise, tratava-se então de um nomem nudum, tornando-se válido apenas em 1881, com a publicação, pela primeira vez, do texto completo da Flora Fluminensis. Kunth, em 1841, publica a combinação Philodendron amphibium (Vellozo) Kunth citando apenas $A$. amphibium (Vellozo, 1831), tratando-se também de um nome ilegítimo, já que foi baseado em um nomem nudum, sem qualquer diagnose. A curta descrição de A. amphibium é traduzida no trabalho de Stellfeld (1950) onde a espécie é tratada como $P$. amphibium (Vellozo) Kunth. Sendo assim, fica prevalecendo o epíteto Philodendron eximium de Schott, publicado em 1853.

Todas as descrições estudadas, juntamente com os ícones e material de herbário, das espécies acima mencionadas, não apresentaram diferenças significativas sugerindo a sinonimização das mesmas prevalecendo o epíteto de Schott, P. eximium.

Os ícones de números 2484, 2485-2493, 2680 e 2681 foram preparados de uma planta cultivada nos Jardins Imperiais do Palácio de Schoenbrunn em Viena, como todas as outras pranchas coloridas da coleção dos Ícones de Schott (Mayo, 1990a: 49). Não existe material em herbário já que a coleção de Schott, depositada no herbário do Museu de Viena, foi destruída durante a Segunda Grande Guerra. Em vista disto, o protólogo consta da descrição original junto com os (13) ícones acima citados. Para simplificar a tipificação do nome Philodendron eximium Schott, seria desejável escolher um destes ícones para servir como lectotypus, visto que o material herborizado original não existe mais. Assim sendo, escolheu-se o ícone $\mathrm{n}^{\mathrm{o}} 2486$ como lectotypus, porque apresenta importantes caracteres do ovário, número de lóculos e dos óvulos, tipo de placentação, etc. É necessário, porém, deixar bem claro que o entendimento preciso da espécie deve ser fundamentado no conjunto total dos ícones desta espécie, desde que a folha e até o próprio hábito contêm, também, importantes caracteres diagnósticos, como na maioria das espécies deste gênero.

De acordo com os critérios de conservação da natureza a espécie é considerada protegida por se encontrar em extensa área geográfica com muita ocorrência comprovada por coleções de herbário.

5.4.5 - Philodendron fragile Nadruz et Mayo, Bolm. Botânica Univ. São Paulo 17: 52. 1998. Typus: Brasil, Rio de Janeiro, Nova Friburgo, Macaé de Cima, estrada entre a pousada da Ana e a entrada da Reserva, mata atlântica, ca. $1100 \mathrm{~m}$, Nadruz 1292 et al., 29.XI.96 (Holotypus RB); Figs. 16, 17 e 18.

Caule cilíndrico, verde levemente lúcido no ápice tornando-se paleáceas a castanho, $1.2-2.2 \mathrm{~cm}$ diâm. Internós $0.8-2.1(-5.5) \mathrm{cm}$ compr. Raízes adventícias amareloesverdeadas quando novas, tornando-se paleáceas até castanhas, $2.0-4.0 \mathrm{~mm}$ diâm. Profilo caduco, esverdeado externamente, creme esbranquiçado a esverdeado internamente quando novo, $21.5 \mathrm{~cm}$ compr., $5.3 \mathrm{~cm}$ larg. na base. Pecíolo subroliço a aplanado na face adaxial e arredondado na inferior, verde com estrias mais escuras, 17.0$27.5 \mathrm{~cm}$ compr., 0.6-0.7cm diâm. Bainha 4.0$6.5 \mathrm{~cm}$ compr. em unidade simpodial adulta em flor. Lâmina quando nova membranácea tornando-se cartácea posteriormente, alongado-ovada a triangular, base subcordada, (15.0-)21.0-25.5(-37.0)cm compr., (5.0-)9.9$24.0 \mathrm{~cm}$ larg., fortemente discolor, mais clara na face abaxial, lúcida em ambas as faces, com linhas glandulares visíveis na face abaxial. Divisão anterior $18.8-25.0 \mathrm{~cm}$ compr., 14.1$18.0 \mathrm{~cm}$ larg. Nervura central levemente mais clara e aplanada na face adaxial e saliente na 
Philodendron Schott (Araceae): morfologia e taxonomia das espécies da Reserva Ecológica de Macaé de Cima - Nova Friburgo, Rio de Janeiro, Brasil

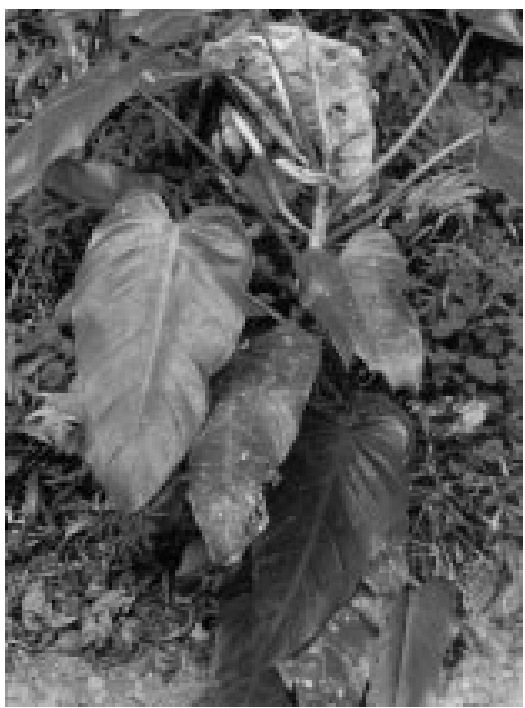

Figura 16 - Philodendron fragile Nadruz \& Mayo Hábito

abaxial. Nervuras laterais primárias impressas na face adaxial e salientes na face abaxial, da mesma cor que a lâmina a levemente mais claras na face adaxial, 4-5 pares. Nervuras interprimárias evidentes. Divisão posterior 1.72.5 (-4)cm compr., 11.0-15.3cm larg., lobos retrorsos, nervura lateral basioscópica 1 e acroscópica 0. Simpódio floral com 1 a, raro, 2 inflorescências. Pedúnculo $3.0-5.5 \mathrm{~cm}$ compr., $0.6-1.1 \mathrm{~cm}$ diâm. na região mediana, esverdeado com estrias mais claras. Espata na antese $12.5 \mathrm{~cm}$ compr., $4.5 \mathrm{~cm}$ larg., fracamente diferenciada entre tubo e lâmina, externamente alva, as vezes rósea na lâmina e verde claro a verde no tubo, internamente creme-esverdeada a creme com pontos mais claros na lâmina e verde tornando-se róseoavermelhada em direção a base no tubo. Espádice em pré-antese $8.5-13.4 \mathrm{~cm}$ compr., na antese $11 \mathrm{~cm}$ compr., com canais de resina ferrugínea abaixo dos estames, zona estaminada fértil esverdeada, $4.4-7.1 \mathrm{~cm}$ compr., $0.5-1.1 \mathrm{~cm}$ diâm., zona estaminada estéril creme, $0.6-1.7 \mathrm{~cm}$ compr., $0.7-1.5 \mathrm{~cm}$ diâm., zona pistilada esverdeada $3.7-4.5 \mathrm{~cm}$ compr., $0.7-1.5 \mathrm{~cm}$ diâm. Estames 2-6 por flor, 1.0-2.0mm compr., 0.9-1.9mm larg. no ápice. Estaminódios 1.6-3.0mm compr., 1.2-3.0mm larg. no ápice. Gineceu 1.5-2.0mm compr., 1.2-

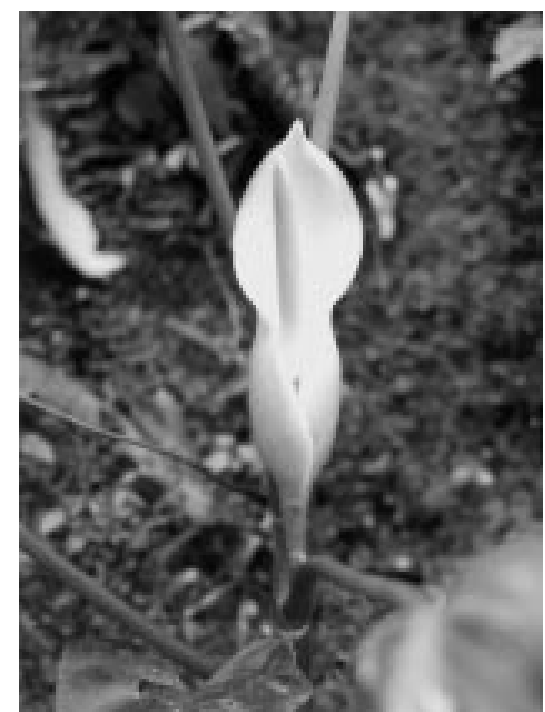

Figura 17 - Philodendron fragile Nadruz \& Mayo Detalhe da inflorescência

$1.7 \mathrm{~mm}$ larg., ovário verde esbranquiçado, estilete esverdeado, estigma globoso, lóculos 7-9 no ovário, óvulos 3 (-5) por lóculo, $0.6 \mathrm{~mm}$ compr., com tricomas nos funículos, placentação sub-basal

Material examinado: Brasil, Rio de Janeiro, Nova Friburgo, Distrito de Macaé de Cima: Sítio Sophronites na beira de estrada, 03.XI.92, Nadruz 775 et al. (Paratypus RB); idem, Nadruz 1002 et al. (Paratypus RB); Fazenda Ouro verde, picada para a torre, 30.VII.93, Vieira 332 et al. (Paratypus - RB); Estrada que corta o Sítio Sophronites, em árvore na beira da estrada, 29.IX.94, Nadruz 1066 (Paratypus - RB); Estrada que liga o Sítio do João Luiz ao Sítio Sophronites, 10.XI.94, Nadruz 1076 (Paratypus - RB);

Philodendron fragile só foi coletado no Município de Nova Friburgo, Estado do Rio de Janeiro. Espécie hemi-epífita muito rara na área, onde foram realizadas, até o presente, somente 2 coletas da espécie. Cresce em locais úmidos e sombreados na floresta pluvial atlântica montana, acima de $1000 \mathrm{~m}$.

Philodendron fragile é espécie próxima de $P$. elongatum, podendo ser diferenciada pela lâmina alongado-ovada a triangular, base subcordada, lobos posteriores 1.7-2.5 (-4)cm comprimento, $11.0-15.3 \mathrm{~cm}$ largura e tubo da 


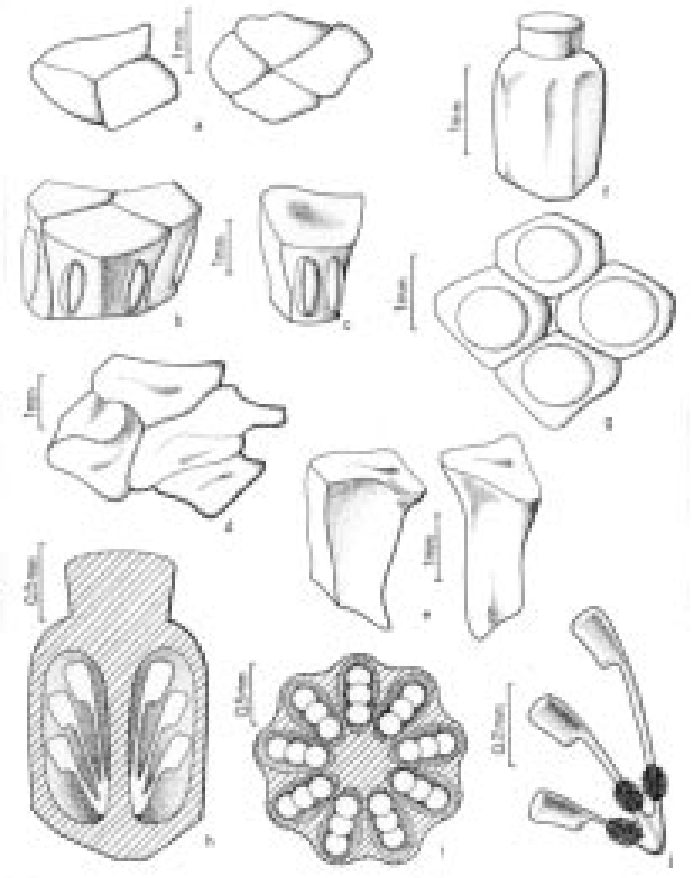

Figura 18 - Philodendron fragile Nadruz \& Mayo (Nadruz 775, 1066) - a. Flores masculinas férteis, em vista apical, com 3-4 estames; $\mathbf{b}$. Detalhe da flor masculina em vista frontal; c. Detalhe do estame em vista frontal; $\mathbf{d}$. Flores masculinas estéreis em vista apical; e. Detalhe dos estaminódios em vista frontal; f. Detalhe do gineceu em vista frontal; $\mathbf{g}$. Flores femininas em vista apical; $\mathbf{h}$. Detalhe do gineceu em corte longitudinal mostrando lóculos com óvulos; i. Detalhe do gineceu em corte transversal mostrando lóculos com óvulos; j. Detalhe dos óvulos com a presença de tricomas nos funículos.

espata internamente verde tornando-se róseo avermelhado em direção a base, enquanto $P$. elongatum possui lâmina alongado-hastadooblonga, lobos posteriores com $12.0-15.0 \mathrm{~cm}$ comprimento, $5.0-7.0 \mathrm{~cm}$ largura e coloração do tubo da espata internamente creme. O nome deve-se à fragilidade de suas folhas e caule.

Conforme critérios da IUCN, a espécie é considerada em perigo por encontrar-se mal protegida em unidade de conservação e ocorrer em área restrita.

\subsection{6 - Philodendron hatschbachii} Nadruz \& Mayo, Bolm. Botânica Univ. São Paulo 17: 52. 1998. Typus: Brasil, Rio de Janeiro, Nova Friburgo, Macaé de Cima, Estrada que leva até a entrada do Sítio
Sophronitis, Nadruz 773 et al., 03.XI.92 (Holotypus RB, Isotypus K); Figs. 19, $20 \mathrm{e}$ 21.

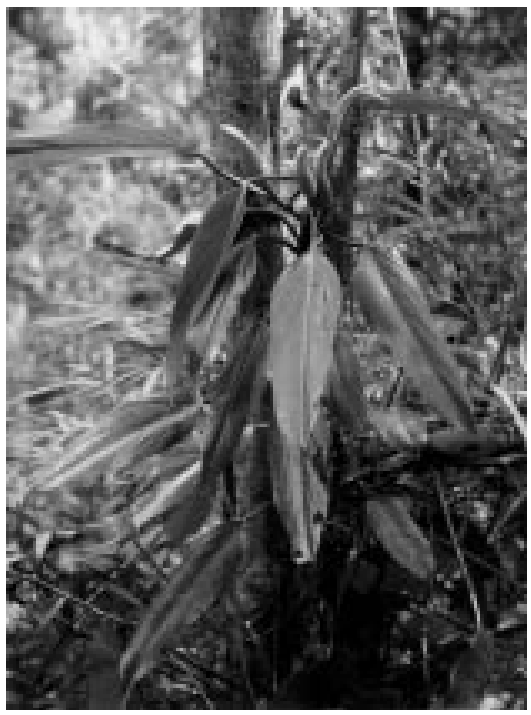

Figura 19 - Philodendron hatschbachii Nadruz \& Mayo - Hábito

Caule cilíndrico, $1.0-1.7 \mathrm{~cm}$ diâm., verde claro quando jovem tornando-se escuro, lúcido a opaco, cinza a paleáceo. Internós $0.8-10.0 \mathrm{~cm}$ compr. Raízes amarelas, amarelo-esverdeadas ou verde claras quando novas tornando-se paleáceas a castanhas posteriormente, 0.1$0.3 \mathrm{~cm}$ diâm. Profilo caduco, verde externamente, mais claro com pontos alvos internamente, $17.5 \mathrm{~cm}$ compr., $1.5 \mathrm{~cm}$ larg. na base. Pecíolo aplanado a levemente sulcado na face adaxial e arredondado na abaxial (12.0-)18.0-27.0cm compr., 0.5-0.8cm diâm., verde com estrias pouco mais escuras, junção da base da lâmina com ápice do pecíolo proeminente com anel esverdeado. Bainha em unidade simpodial adulta em flor $3.5-9.0 \mathrm{~cm}$ compr. Lâmina elíptica, oblonga, oblongolanceolada a levemente ovada, margem inteira, base arredondada a levemente cuneada, $15.0-31.5 \mathrm{~cm}$ compr., $5.2-12.0 \mathrm{~cm}$ larg., verde fortemente discolor, mais clara na inferior, lúcida em ambos as faces a pouco lúcida na face abaxial, cartácea, linhas glandulares proeminentes na face abaxial. Nervura principal impressa na face adaxial, saliente na 
Philodendron Schott (Araceae): morfologia e taxonomia das espécies da Reserva Ecológica de Macaé de Cima - Nova Friburgo, Rio de Janeiro, Brasil

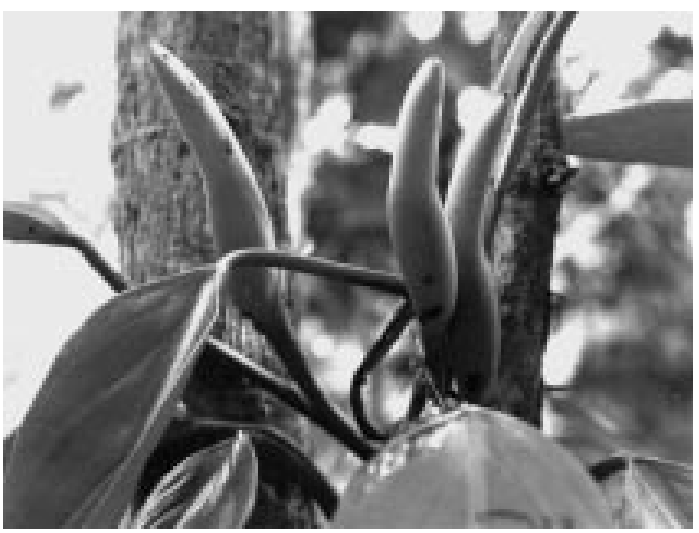

Figura 20 - Philodendron hatschbachii Nadruz \& Mayo - Detalhe da inflorescência

abaxial, concolor. Nervuras laterais primárias impressas na face adaxial, salientes na abaxial, 4-5 pares. Nervuras interprimárias pouco desenvolvidas. Simpódio com uma única inflorescência. Pedúnculo $4.0 \mathrm{~cm}$ compr., $1.0 \mathrm{~cm}$ diâm. no ápice, verde com estrias claras. Espata em antese ca. $13.0 \mathrm{~cm}$ compr., ca. $3.5 \mathrm{~cm}$ diâm., pré-antese (5.5-) 8.0-9.5cm compr., com leve diferenciação entre tubo e lâmina, curvada, externamente verde na região do tubo com linhas pontilhadas brancas, lâmina verde esbranquiçada a branca com estrias mais claras, internamente totalmente branca com pontos brancos. Espádice curvado, $13.0 \mathrm{~cm}$ compr., zona estaminada estéril apical creme esverdeada $0.5 \mathrm{~cm}$ compr., $1.4 \mathrm{~cm}$ diâm., zona estaminada fértil $6.5 \mathrm{~cm}$ compr., $1.0 \mathrm{~cm}$ diâm., verde clara, com canais de resina ferrugínea abaixo dos estames, zona estaminada estéril basal creme esverdeada $2.0 \mathrm{~cm}$ compr., zona pistilada esverdeada com $4.5 \mathrm{~cm}$ compr., $1.4 \mathrm{~cm}$ diâm., região adnata com a espata de 2.0-3.5 cm compr. Estames $3(-5)$ por flor, $2.0 \mathrm{~mm}$ altura e $1.5-1.8 \mathrm{~mm}$ larg. no ápice. Estaminódios 3.0-3.5mm compr., 1.5-2.0mm larg. no ápice. Gineceu verde esbranquiçado, $3.5 \mathrm{~mm}$ altura e $2.5 \mathrm{~mm}$ larg., ovário oblongo, lóculos 10-12, óvulos 4 por lóculo, placentação sub-basal, $0.5 \mathrm{~mm}$ compr., estigma globoso. Frutos jovens de cor creme.

Material examinado: Brasil, Espírito Santo: Muniz Freire, rod. BR 262, crescendo ao longo do tronco de árvores da mata pluvial,

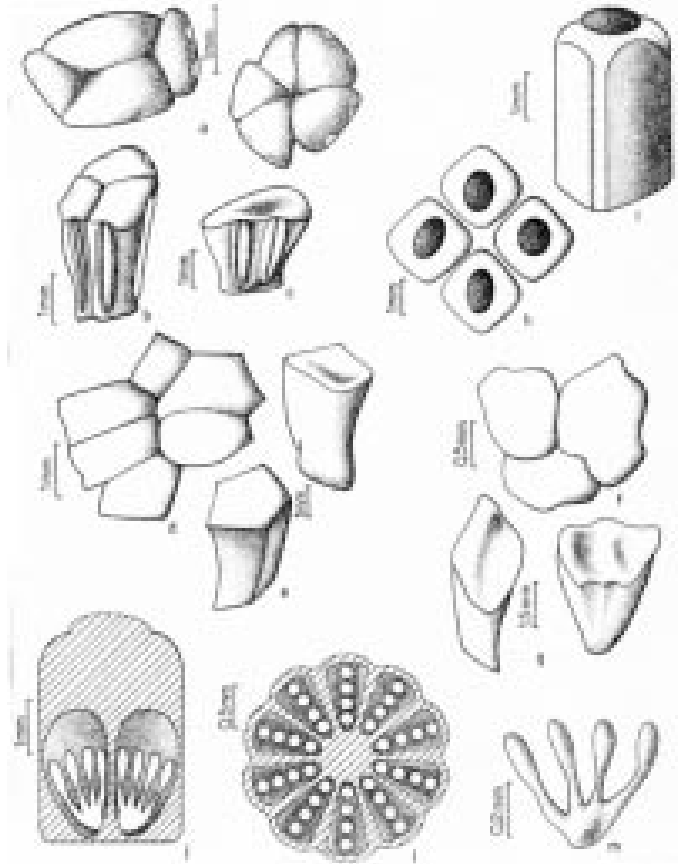

Figura 21 - Philodendron hatschbachii Nadruz \& Mayo (Nadruz 1064, 773, Gomes 438, 437) - a. Flores masculinas férteis, em vista apical, com 4-5 estames; $\mathbf{b}$. Detalhe da flor masculina em vista frontal; $\mathbf{c}$. Detalhe do estame em vista frontal; d. Flores masculinas estéreis basais em vista apical; e. Detalhe dos estaminódios basais em vista frontal; f. Flores masculinas estéreis apicais em vista apical; g. Detalhe dos estaminódios apicais em vista frontal; h. Flores femininas em vista apical; i. Detalhe do gineceu em vista frontal; $\mathbf{j}$. Detalhe do gineceu em corte longitudinal mostrando lóculos com óvulos; l. Detalhe do gineceu em corte transversal mostrando lóculos com óvulos; m. Detalhe dos óvulos.

05.XII.84, G. Hatschbach \& J.M. Silva 48621 (Paratypus - K, MBM); Ibatiba, $21 \mathrm{~km}$ leste de Ibatiba, alt. $900 \mathrm{~m}$, cresce ao longo do tronco de árvore, mata pluvial, 04.VIII.83, G. Hatschbach 46686 (Paratypus - MBM, K); Conceição do Castelo, Alto Bananal., cresce ao longo do tronco de árvores de mata pluvial, 10.VIII.85, G. Hatschbach \& J.M. Silva 49945 (Paratypus - K, MBM). Rio de Janeiro, Nova Friburgo, Distrito de Macaé de Cima: Próximo ao Hotel Garlipp., 19.X.91, Gomes 438 et al (RB); idem, Gomes 437 et al. (Paratypus - RB); Estrada que chega ao Sítio Sophronites, 15.VII.92, Nadruz 751 et al. (Paratypus - RB); Sítio Bacchus, estrada do Hotel Fazenda São João, 02.II.92, Nadruz 754 et al. (Paratypus - RB, K); Picada para Pedra 
Bicuda, 23.III.94, Nadruz 1004 et al. (Paratypus - RB); Estrada principal. que corta a Reserva, entre o Hotel Fazenda São João e o sítio do João Luís, beirando o Rio Macaé, 19.IV.94, Nadruz 1014 (Paratypus - RB); Idem, 19.IV.94, Nadruz 1017 (Paratypus RB); Estrada entre o Hotel Fazenda São João e o Sítio Fazenda Velha, na beira do Rio Macaé, 980m, 26.IX.94, Nadruz 1064 (Paratypus RB); Fazenda Ouro Verde, mata secundária, 25.VI.93, Vieira 291 (Paratypus - RB);

Philodendron hatschbachii distribui-se pelos estados do Espírito Santo e Rio de Janeiro. Hemi-epífita da floresta pluvial atlântica montana, cresce em locais úmidos e sombreados, mas por vezes é encontrada a pleno sol, podendo chegar a $1100 \mathrm{~m}$.

Philodendron hatschbachii é próxima de $P$. fragile, diferenciando-se pela lâmina elíptica, oblonga, oblongo-lanceolada a levemente ovado-oblonga, com a base arredondada a levemente cuneada, espata e espádice curvos, tubo da espata branco internamente com pontos leitosos e 10-12 lóculos no ovário, enquanto $P$. fragile possui lâmina alongado-ovada a triangular, base subcordada, espata e espádice retos, tubo da espata verde internamente, tornando-se róseo avermelhado em direção à base e 7-9 lóculos no ovário.

O epíteto específico homenageia o Dr. Gert Hatschbach, cujas coletas de Araceae (e de outras famílias) têm enriquecido nosso conhecimento da flora brasileira. Esta espécie foi primeiramente coletada por ele no estado do Espírito Santo.

\subsubsection{Philodendron ochrostemon} Schott, Prodr. Syst. Aroid. 229. 1860; Vellozo Fl. Flum. IX: t. 115. 1827; Engler in C.F.P. von Martius, Flora Brasiliensis 3(2) :25-224, tt. 252; Krause in Engler, Das Pflanzenreich IV 23 Db. 60: 9. 1913. Typus: "Schott Icones Aroidearum" no 2412 (Lectotypus W!). Figs. 22,23 e 24.

Caule levemente 2-angular, com uma das faces aplanada a levemente sulcada, de verde

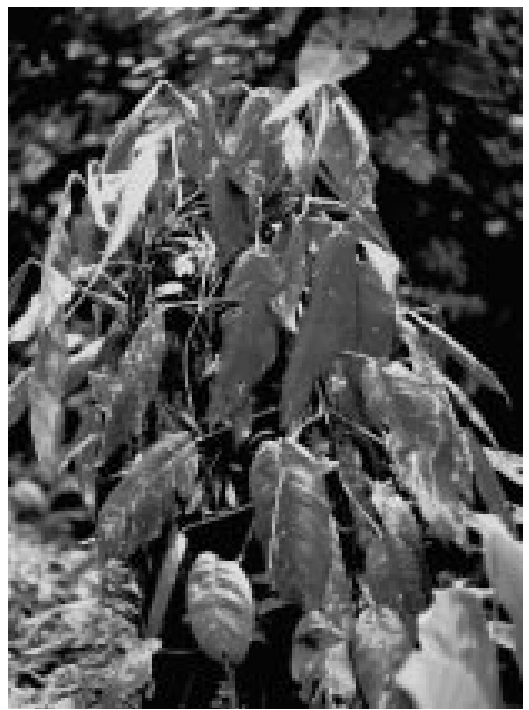

Figura 22 - Philodendron ochrostemon Schott - Hábito

claro a verde escuro lúcido tornando-se cor de palha opaco, 0.4-0.9(-1.1)cm diâm. no flagelo e $0.6-1.8 \mathrm{~cm}$ diâm. no caule não flagelar. Catafilos do flagelo esverdeados discolores, nervuras dos catafilos muito levemente discolores com o catafilo. Internós 1.0-6.5($19.0) \mathrm{cm}$ compr., sendo até $20.5 \mathrm{~cm}$ de compr. no flagelo. Raízes de creme a creme levemente esverdeada a verde-amareladas com ápice vermelho quando novas, tornando-se castanhas com o passar do tempo, $1.0-2.5 \mathrm{~mm}$ diâm. Profilo do simpódio floral persistente, membranáceo, verde sendo mais claro interiormente tornando-se castanho com o passar do tempo, $6.5-13.0 \mathrm{~cm}$ compr. e 1.0 $1.7 \mathrm{~cm}$ larg. na base. Pecíolo de verde brilhante a pouco brilhante, levemente estriado com estrias mais escuras em ambos os lados, arredondado na face inferior e de aplanado a raramente levemente sulcado na face superior, (5.8-)12.0-22.0cm compr. e 0.2-0.4cm diâm. no ápice, sendo $0.3-2.9 \mathrm{~cm}$ compr. livre. Bainha concolor, pouco lúcida, com estrias mais escuras, alongada até $0.3 \mathrm{~cm}$ da base da lâmina, (5.8) $12.7-20.8 \mathrm{~cm}$ compr. e $0.6-0.8 \mathrm{~cm}$ larg., fechada com margens eretas, levemente expandida na base quando em floração. Lâmina foliar de levemente ovado-oblonga a oblongo-lanceolada a elíptico-lanceolada, (8.0)20.0-36.0 cm compr. e (2.8-)5.0-8.7(-15.4)cm 
Philodendron Schott (Araceae): morfologia e taxonomia das espécies da Reserva Ecológica de Macaé de Cima - Nova Friburgo, Rio de Janeiro, Brasil

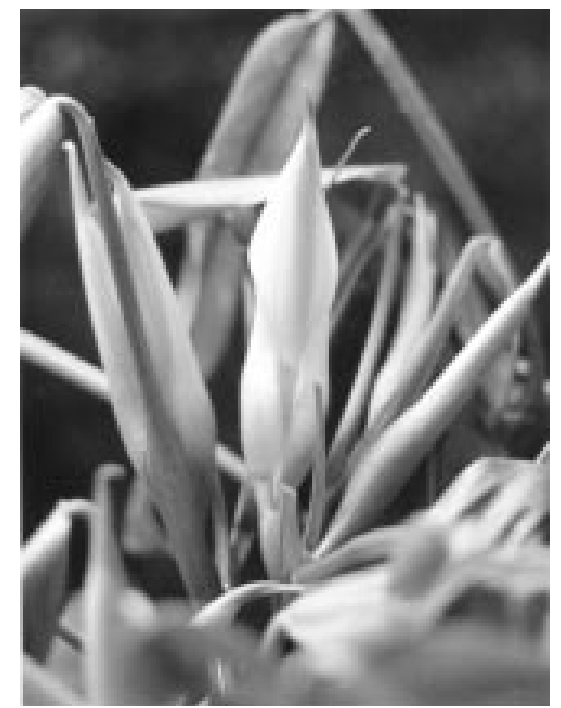

Figura 23 - Philodendron ochrostemon Schott - Detalhe da inflorescência

larg., verde de muito a levemente lúcida em ambos os lados quando nova a lúcida na face superior, e verde mais claro e lúcida a levemente lúcida na face inferior, membranácea a levemente cartácea, ápice rostrado, base de levemente cordada a arredondada a obtusa a atenuada, margem inteira. Nervura central, em relação à lâmina, levemente discolor a concolor na face superior e discolor, sendo mais clara, na inferior, impressa na face superior e saliente na inferior. Nervuras laterais primárias concolores, impressas na face superior e salientes, mas não muito evidentes, na inferior, 4-6 pares. Simpódio floral 1-2 inflorescências. Pedúnculo verde com estrias de mais escuras a mais claras no ápice, anguloso, $1.5-5.0 \mathrm{~cm}$ compr. e $0.8 \mathrm{~cm}$ diâm. Espata $10.5-16.5 \mathrm{~cm}$ compr., leve diferenciação entre tubo e lâmina, lâmina externamente verde, verde amarelada a creme e internamente creme com canais de resina amarelados, tubo externamente verde claro com linha dorsal verde escuro da base até o meio, internamente creme com canais de resina amarelados. Espádice $13.1 \mathrm{~cm}$ de compr., estípite presente $1.3-2.0 \mathrm{~cm}$ compr., decorrência da espata 1.7-2.3cm compr., zona masculina fértil creme, (4.5-)5.6-11.0cm compr. e $0.8-1.1 \mathrm{~cm}$ diâm., zona masculina

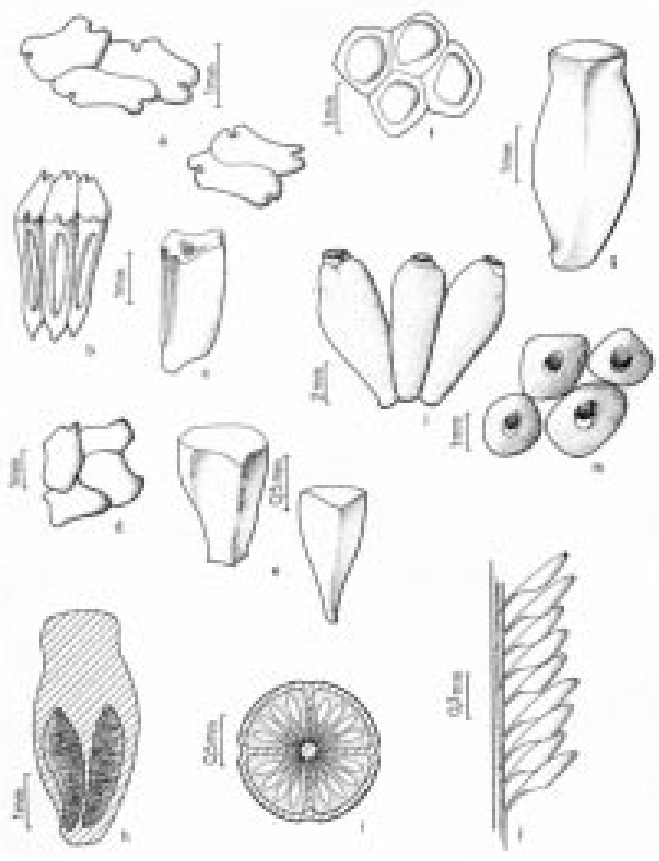

Figura 24 - Philodendron ochrostemon Schott. (Nadruz 1074, 1020, 1011, 996, 993) - a. Flores masculinas férteis, em vista apical, com 2-3 estames; b. Detalhe da flor em vista frontal; c. Detalhe do estame em vista lateral; d. Flores masculinas estéreis em vista apical; e. Detalhe de estaminódios em vista frontal; f. Flores femininas em vista apical. g. Detalhe do gineceu em vista frontal; $\mathbf{h}$. Detalhe do gineceu em corte longitudinal mostrando lóculos com óvulos; i. Detalhe do gineceu em corte transversal mostrando lóculos com óvulos; j. Detalhe dos óvulos em placentação axilar; I. Bagas em vista frontal; m. Bagas em vista apical.

estéril creme levemente mais claro, $0.5-1.0 \mathrm{~cm}$ compr. e $1.0-1.9 \mathrm{~cm}$ larg., zona feminina esverdeada, $4.0-5.5 \mathrm{~cm}$ compr. e $1.6 \mathrm{~cm}$ de diâm. Estames 2-3 por flor, (1.1-)2-2.5mm de compr. e 1.0-1.5 (-1.8)mm de larg. no ápice. Estaminódios 4.0mm compr. e 1.5-2.0mm larg. no ápice, afilados na base. Gineceu com ovário esverdeado, $4.0 \mathrm{~mm}$ de compr. e $1.2-1.5 \mathrm{~mm}$ de larg., lóculos 3-4, óvulos vários por lóculo, $0.6 \mathrm{~mm}$ de compr., placentação axilar, estigma globoso castanho. Infrutescência madura, 7.0$8.0 \mathrm{~cm}$ compr. e $2.3-3.4 \mathrm{~cm}$ diâm. Frutos imaturos verdes e maduros de verdeamarelados a amarelados, $7.0-8.0 \mathrm{~mm}$ de compr. e 2.0-2.5mm de larg. na região mediana, sementes não observadas por estarem galhadas. 
Material Examinado: Rio de Janeiro, Nova Friburgo, Macaé de Cima: Caminho para a nascente do Rio Macaé, depois da entrada para o Sítio do João Luís, 17.01.91, Pessoa et al. 558 (RB); Sítio Sophronites, área da parcela, 23.03.92, Nadruz et al. 740 (RB); Sítio Bacchus, estrada do Hotel Fazenda São João, 02.11.92, Nadruz et al. 755 (RB, K); Sítio Sophronites, mata atlântica de encosta, 22.03.94, Nadruz et al. 993 (RB); Idem, idem, 22.03.94, Nadruz et al. 994 (RB); Idem, idem, 22.03.94, Nadruz et al. 996 (RB); Estrada de Santa Fé, 19.04.94, Nadruz 1011 (RB); Estrada principal que corta a Reserva, entre Hotel Fazenda São João e Sítio do João Luís, beirando o Rio Macaé, 19.04.94, Nadruz 1020 (RB); Idem, idem, 19.04.94, Nadruz 1022 (RB); Estrada principal do Sítio Bacchus, 10.11.94, Nadruz 1074 (RB); Sítio Sophronites, trilha para a parcela 1, 28.10.90, Sylvestre et al. 381 (RB);

Conhecida vulgarmente como "imbé miúdo", “cipó de imbé”, "cipó guimbé”, "tracuá" e "curuba", P. ochrostemon tem sua distribuição geográfica nos estados do Distrito Federal, Espírito Santo, Rio Grande do Sul, Santa Catarina, São Paulo e Rio de Janeiro nos municípios de Magé, Nova Friburgo, Paraty, Petrópolis, Rio Bonito, Rio de Janeiro, Santa Maria Magdalena.

Espécie hemi-epífita, podendo ser encontrada em floresta pluvial atlântica baixo montana, de encosta e cerradão em locais úmidos e sombreados, chegando a $1100 \mathrm{msm}$.

Até o momento o nome $P$. ochrostemon vinha sendo confundido e utilizado para aquela espécie que possui, principalmente, a bainha larga e aberta, erroneamente denominada $P$. sonderianum (hoje $P$. propinquum Schott). Segundo as observações feitas nos Icones de Schott números 2410, 2411, 2412 e 2712, e nas estampas de Krause (1913) e Engler (1878), conclui-se que as bainhas, para P. ochrostemon, são largas e fechadas. Além deste caráter, há outros descritos por Schott (1860), como: bainha não atingindo o limite do pecíolo com a lâmina; lâmina foliar adulta oblongo-ovada ou oblonga, com base arredondada e ápice curtamente cuspidado, levando a crer ser essa, sem dúvida nenhuma, a espécie por mim coletada na área.

Engler (1878) coloca, duvidosamente, $P$. ambiguum, como sinônimo de $P$. ochrostemon . Contudo a descrição original de $P$. ambiguum, Schott (1860) cita "vagina latiuscula, ..., explanata", característica essa facilmente observada nos Ícones de números 3588 e 3590 , confirmando assim as duas espécies como distintas.

Engler (1878) e Krause (1913) citam, erroneamente, Philodendron nervosum Schott como sinônimo também. Segundo Croat (1986), Kunth (1841) interpretou mal a ortografia do nome Pothos venosa Willd e ilegitimamente criou a combinação $P$. nervosum Schott, sendo seguido erroneamente por Engler e Krause. A espécie ocorre do nordeste da Venezuela até Trinidad.

O Ícone de número 2412 para lectotypus foi escolhido por M. Grayum (1996). Schott (1860) citou "Insula St. Catharinae, Brasiliae 1. Brasilia Australior - v. v. cult." como referência do local do material original, mas não citou um tipo detalhadamente. Segundo Grayun (1996), é de supor que Schott, aparentemente, baseou sua descrição em material vivo deste local que tinha em cultivo. Presumivelmente, Schott preparou espécimens de herbário de suas próprias plantas, mas essas teriam sido destruídas, em Viena (W), durante a Segunda Guerra Mundial. Em vista disto, Grayum optou pela lectotipificação do Ícone de Schott de número 2412 por reunir as características principais, lembrando que o conjunto dos Icones (i.e. números 2408-2412 e 2417) é indispensável para a correta identificação taxonômica da espécie.

De acordo com os critérios de conservação da natureza a espécie é considerada protegida por encontrar-se bem protegida em unidade de conservação e com muita ocorrência comprovada por coleções de herbário. 
Philodendron Schott (Araceae): morfologia e taxonomia das espécies da Reserva Ecológica de Macaé de Cima - Nova Friburgo, Rio de Janeiro, Brasil

5.4.8. Philodendron ornatum Schott in Oesterr. bot. Wochenbl. 3: 378. 1853; C. Koch in Index sem. hort. bot. reg. berol. Appendix 14. 1853. Appendix 8. 1854. Appendix 3. 1855. Schott, Prodr. Syst. Aroid. 247. 1860. Krause in Engler (ed.), Das Pflanzenreich 60 (IV.23Db):51. 1913. Typus: "Schott Icones Aroidearum" no 2417 (lectotypus W!), "Brasilien..."; Figs.: 25, 26 e 27.

$=$ Zantedeschia asperata $\mathrm{C}$. Koch in Index sem. hort. bot. reg. berol. appendix 5 . 1853. Typus: Espécie cultivada no Horto Berolinensis, mas sem o registro de localidade.

$=$ Philodendron asperatum (C. Koch) C. Koch in Index sem. hort. bot. reg. berol. appendix 4. 1855.

$=$ Philodendron imperiale Schott in Oesterr. bot. Zeitschr. 15: 71. 1865. Typus: "Schott Icones Aroidearum" no 3620 (LECTOTIPO W!) "Provincia Bahiensis Brasiliae".

$=$ Philodendron dolosum Schott in Oesterr. bot. Zeitschr. 15: 71. 1865. Typus: "Schott Icones Aroidearum" no 2676 (LECTOTIPO W!) "Brasilia".

= Philodendron muschlerianum $\mathrm{K}$. Krause in Engler, Das Pflanzenreich 60: 50. 1913. Typus: Brasil, Rio Acre, near São Francisco, na floresta, Abril 1911, E. Ule 9226 (B, MG, K, G).

Caule verde opaco $4.0-4.5 \mathrm{~cm}$ diâm. Internós $1.0-3.5 \mathrm{~cm}$ de compr. no ápice do caule. Raízes adventícias novas vináceas com ápice amarelado, tornando-se castanhas, opacas, $0.3-0.4 \mathrm{~cm}$ diâm. Catafilo persistente, logo apodrecendo e formando massa fibrosa castanho escuro. Profilo creme levemente rosado a verde-rosado tornando-se avermelhado em direção a base com estrias verdes no dorso, $26.5-33.0 \mathrm{~cm}$ compr. e 2.3$10.0 \mathrm{~cm}$ larg. na base. Pecíolo quando jovem verde e, quando adulto verde, sendo, raramente, vinoso na base e no ápice, presença de verrugas mais claras com pontas esbranquiçadas no ápice, $45.0-60.0 \mathrm{~cm}$ compr. e $1.3 \mathrm{~cm}$ diâm., opaco, aplanado na superfície superior e arredondado na inferior. Bainha

Rodriguésia 51(78/79): 21-68. 2000

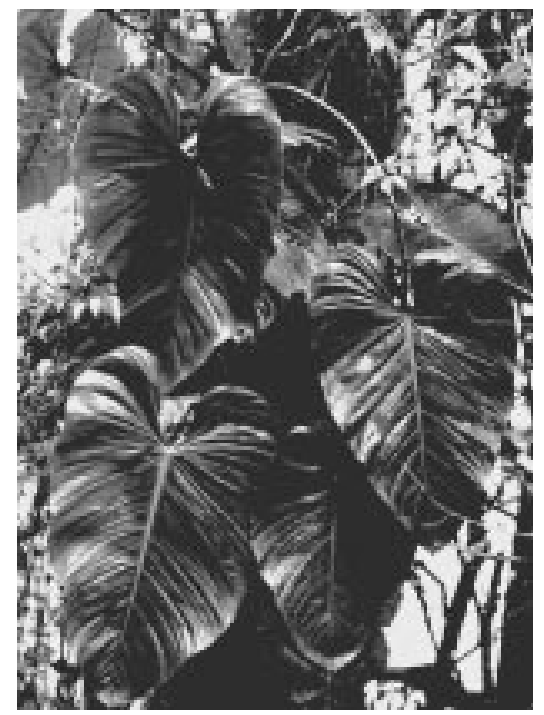

Figura 25 - Philodendron ornatum Schott - Hábito

foliar verde, raramente verde rosado, em unidade simpodial adulta florida $7.0-8.5 \mathrm{~cm}$ de compr. Lâmina cartácea, ovado-cordada, lúcida em ambos os lados, verde discolor sendo mais clara na face inferior. Divisão anterior 36.0$39.2 \mathrm{~cm}$ compr. e $30.8-31.0 \mathrm{~cm}$ larg., ápice obtuso apiculado. Nervura principal verde clara e aplanada na superfície superior e rosada a vinácea com estrias claras e proeminentes na superfície inferior. Nervuras laterais primárias impressas e concolores na superfície superior e salientes e rosadas a vináceas na inferior, 57(-9) pares. Nervuras interprimárias pouco visíveis. Divisão posterior $13.0-15.0 \mathrm{~cm}$ compr. e $29.0-30.0 \mathrm{~cm}$ larg., nervuras primárias acroscópicas 1-2 e basioscópicas 3, lobos superpostos a levemente superpostos, retrorsos a levemente introrsos, Sinus parabólico. Simpódio floral com 1-2 inflorescências. Pedúnculo verde, creme-esverdeado a rosa com estrias brancas, $2.5-3.8 \mathrm{~cm}$ compr. e 1.2$2.0 \mathrm{~cm}$ diâm. Espata 19.0-19.5cm de compr., em antese levemente diferenciada em tubo e lâmina, tubo externamente verde a verderosado com estrias brancas e internamente creme, lâmina externamente verde mais clara com estrias brancas e internamente creme com pontos brancos, área adnata da espata, (3.5)4.2-4.8cm compr. Espádice (10.0-)15.0$16.3 \mathrm{~cm}$ de compr., com estípite de $0.8-1.0 \mathrm{~cm}$ de compr. Zona masculina fértil creme, 8.0- 


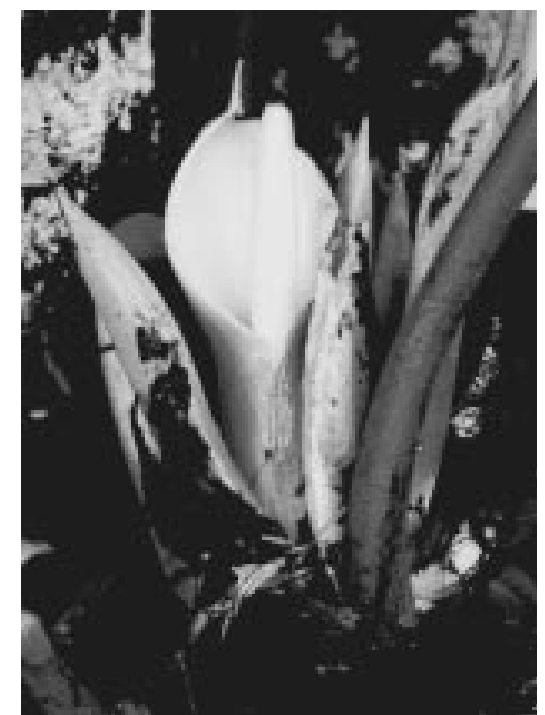

Figura 26 - Philodendron ornatum Schott - Detalhe da inflorescência

$8.4 \mathrm{~cm}$ de compr. e $1.1-1.3 \mathrm{~cm}$ de diâm. Zona masculina estéril creme, $1.5 \mathrm{~cm}$ de compr. e $1.5 \mathrm{~cm}$ de diâm. Zona feminina verde, 4.7$6.2 \mathrm{~cm}$ de compr. e $1.2-1.8 \mathrm{~cm}$ de diâm. Estames 4-6 por flor, canais de resina ferrugínea na base dos estames, $2.0 \mathrm{~mm}$ de compr. e $1.5-1.9 \mathrm{~mm}$ de larg. no ápice. Estaminódios com raros canais de resina ferrugínea na base, 2.3-2.5mm de compr. e 2.2$4.0 \mathrm{~mm}$ de larg. no ápice. Gineceu: ovário $4.0 \mathrm{~mm}$ de compr. e $1.1 \mathrm{~mm}$ de larg. no ápice, creme-esverdeado, estigma globoso, lóculos (3-)4(-5), óvulos vários por lóculo, $0.6 \mathrm{~mm}$ de compr., placentação axilar. Infrutescência madura, $9.5 \mathrm{~cm}$ compr. e $3.0 \mathrm{~cm}$ diâm. na zona mediana, bagas oblongas estreitando-se para a base, $5.5-6.0 \mathrm{~mm}$ de compr. e $3.0 \mathrm{~mm}$ de larg. no ápice, cremes com várias sementes.

Material Examinado: Rio de Janeiro, Nova Friburgo, Macaé de Cima: Sítio Sophronites, estrada e picada, 03.11.92, Nadruz et al. 778 (RB, K). Estrada principal que corta a Reserva, entre Hotel São João e Sítio João Luís, beirando o Rio Macaé, 19.04.94, Nadruz 1015 (RB); Estrada principal da Reserva, logo após o Hotel Fazenda São João, a beira do Rio Macaé, 10.12.94, Nadruz 1087 (RB);

Espécie conhecida pelo nome vulgar de "filodendro", distribuindo-se pelos estados do
Acre, Amazonas, Pará, Rondônia, Pernambuco, Bahia, Minas Gerais, Espírito Santo, São Paulo e Rio de Janeiro nos municípios de Itatiaia, Macaé, Magé, Nova Friburgo e Paraty.

Espécie hemiepífita, ocorrendo em floresta pluvial atlântica baixo-montana, de encosta, matas de restinga e floresta amazônica em locais úmidos e sombreados podendo chegar a $1100 \mathrm{msm}$.

Koch, em 1853 (ou possivelmente 1854), publica, como espécie nova e somente baseada em caracteres vegetativos, Zantedeschia asperata citando que "não havia dúvida sobre esta espécie, que está no Horto Berolinensis e que já havia sido coletada com o nome de Philodendron asperatum”. Em 1855 (ou

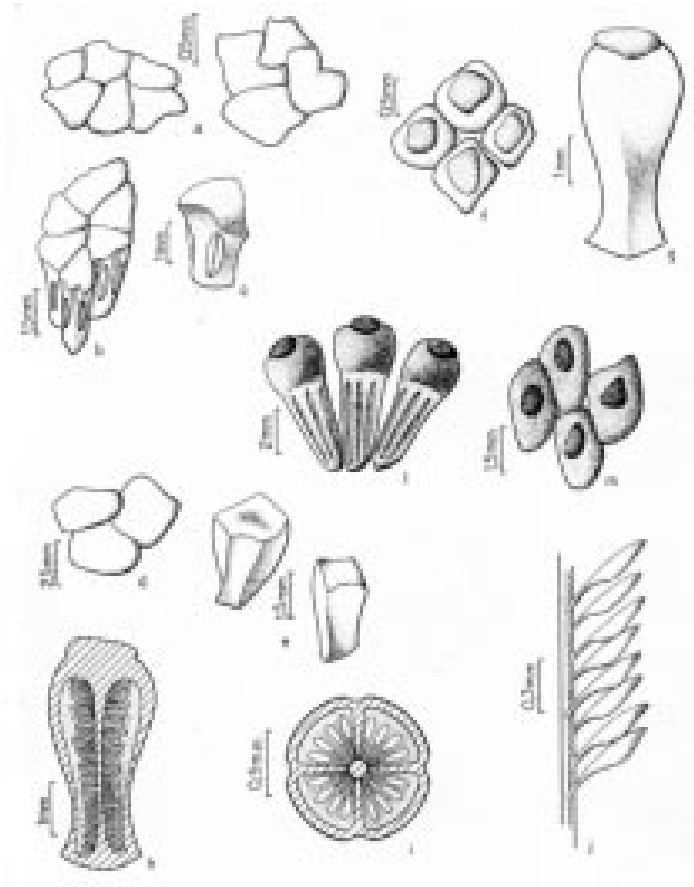

Figura 27 - Philodendron ornatum Schott. (Nadruz 1087) - a. Flores masculinas férteis, em vista apical, com 4-6 estames; $\mathbf{b}$. Detalhe da flor masculina em vista frontal; c. Detalhe do estame em vista frontal; $\mathbf{d}$. Flores masculinas estéreis em vista apical; e. Detalhe de estaminódios em vista frontal; f. Flores femininas em vista apical; g. Detalhe do gineceu em vista frontal; $\mathbf{h}$. Detalhe do gineceu em corte longitudinal mostrando lóculos com óvulos; i. Detalhe do gineceu em corte transversal mostrando lóculos com óvulos; j. Detalhe dos óvulos em placentação axilar; l. Bagas em vista frontal; $\mathbf{m}$. Bagas em vista apical. 
Philodendron Schott (Araceae): morfologia e taxonomia das espécies da Reserva Ecológica de

possivelmente 1856), publicou a nova combinação Philodendron asperatum, a qual viu vivo e cultivado ("v.v. cult."), onde descreveu somente os dados de inflorescência colocando em sinonímia Zantedeschia asperata. (Não se conhece a data exata da publicação do "Index Seminum horto botanico regio berolinense" e seus "Appendix". Autores anteriores (p.ex. Mayo 1985) propuseram que o mesmo foi publicado até o final do ano ou no início do ano seguinte àquele impresso na capa. Com isto, o nome P. ornatum Schott tem prioridade, sendo seguramente publicado no dia $1^{\circ}$ de dezembro de 1853. Provavelmente Koch (1855) fez duas descrições da mesma planta mas em épocas diferentes, esperando, talvez, a floração na espécie da qual observou 2 anos após a primeira citação. Infelizmente o tipo desta espécie foi destruído, sobrando apenas os ícones de Schott (números 2477, 2658 e 2659) para Philodendron asperatum que mostra, sem dúvida nenhuma, ser a mesma espécie de Philodendron ornatum.

Schott, em 1865, publica Philodendron imperiale e Philodendron dolosum, e observa que em Philodendron dolosum, as diferenças em relação a $P$. ornatum seriam "as lâminas mais produzidas, as nervuras laterais secundárias obsoletas, nervuras laterais primárias esverdeadas no dorso, não branco amareladas, e tubo da espata colorido e o cúspide mais curto", características estas não suficientes para a manutenção desta espécie. Em Philodendron imperiale, ele cita máculas irregulares esverdeadas esparsas na face superior da lâmina como única diferença em relação a $P$. ornatum, sendo que não é forte o bastante para manutenção da espécie. Com as descrições originais juntamente com as estampas (Peyritsch, 1879) e os ícones de Schott (Schott, 1984), conclui-se que ambas as espécies possuem caracteres semelhantes a Philodendron ornatum sendo, portanto, sinônimos deste.

Na citação das obras princeps em $P$. imperiale e $P$. dolosum foi acrescentada a obra de Peyritsch (1879) já que as descrições foram feitas por Schott e as estampas realizadas sob sua orientação, apesar da demora na conclusão destas, 14 anos depois da publicação, por Schott (1865), das espécies citadas. Portanto considera-se quase que uma complementação da descrição original (Schott 1865), além de apresentar com mais detalhes a localidade de coleta permitindo uma melhor interpretação do material typus. Os tipos de $P$. imperiale e $P$. dolosum foram destruídos (Mayo, com. pess.) restando apenas os ícones de Schott no 3618-3627A e 2448-2450, 26752677 respectivamente, sendo assim os Ícones 3620 para $P$. imperiale e 2449 para $P$. dolosum foram escolhidos para os respectivos Lectotypus porque apresentam caracteres marcantes que são as verrugas ao longo do pecíolo e pelos grandes catafilos membranáceos persistentes em massa fibrosa, sem com isso desprezar o conjunto total dos ícones que contém, também, importantes caracteres diagnósticos.

Mayo (1986a), na Flora de Trinidad e Tobago, cita $P$. rubens como mais um sinônimo de $P$. ornatum, entretanto Croat (1986) duvida desta colocação, já que não observou os catafilos persistentes (que em adição aos pecíolos verrucosos é o caráter mais distinto de $P$. ornatum) nem a forma mais estreitada da porção pistilar em relação a estaminodial (Schott, 1856) nos ícones de Schott $\left(\mathrm{n}^{\circ} 2723 \mathrm{e}\right.$ 2733). Sendo assim, seria melhor não considerar $P$. rubens como sinônimo de $P$. ornatum.

Outra espécie muito próxima a $P$. ornatum é $P$. muschlerianum, do Acre, citada por Krause (1913). Segundo sua citação original: "Foliorum petiolus supra latiuscule canaliculatus... praesertim apicem versus verruculis minutis densiusculis asperatus; flores masculi plerumque 3-4-andri" juntamente com o fototypus de $\mathrm{n}^{\circ} 12246$ (F!), constata-se que esta espécie está bem de acordo com $P$. ornatum, considerando-se, portanto, mais um sinônimo para esta.

Espécie caracterizada pelos pecíolos verrucosos apicalmente e pelos grandes 
catafilos membranáceos persistentes em massa fibrosa.

Philodendron ornatum foi cultivado no Palácio de Schoenbrunn, Viena e provavelmente originalmente coletado no Brasil por Schott. Não existe material em herbário já que a coleção de Schott, depositada no herbário do Museu de Viena, foi destruída durante a Segunda Grande Guerra. Em vista disso, o protólogo consta da descrição original junto com os ícones de Schott de número 2453, 2454, 2713, 2714 e 2715. Para simplificar a tipificação do nome Philodendron ornatum, optou-se por escolher um destes ícones para servir como lectotypus, visto que o material herborizado não existe mais. Assim sendo escolheu-se o ícone de número 2714 como lectotypus, por este apresentar importantes caracteres da espata, do espádice e das flores. É necessário, porém, deixar claro que o entendimento preciso da espécie deve ser fundamentado no conjunto total dos ícones desta espécie, desde que a folha e até o próprio hábito contenham, também, importantes caracteres diagnósticos, como na maioria das espécies deste gênero.

De acordo com os critérios de conservação da natureza a espécie é considerada protegida por encontrar-se bem protegida em unidade de conservação e com muita ocorrência comprovada por coleções de herbário (Carauta, 1989).

\subsubsection{Philodendron propinquиm} Schott, Synopsis Aroidearum: 78. 1856; Icon. Aroid. t. I-V. 1857a; Prodr. Syst. Aroid. 226 1860; Engler in Martius, Flora Brasiliensis III. 2 :133, 147. 1878; Krause in Engler Das Pflanzenreich 60 (IV. 23. Db): 60. 1913. Typus: Brazil, Rio de Janeiro, Tijuca, nov. 1836, Gardner s.n. (K "sheet 1", lectotypus, escolhido por Grayum, no prelo); Figs.: 28 e 29.

= Monstera cuspidata Gardner in Hook. Lond. Journ. Bot. I :540. 1842. Typus: Brazil. Rio de Janeiro, “on trees woods Gavea," Nov 1836, Gardner s.n. (BM).

$=$ Philodendron ambiguum Schott,
Prod. Syst. Aroid. 227. 1860. Typus: Brasil ("Brasilia") "Caladium, in arborib.", Riedel s.n. (holotypus LE, representado pela prancha Ícone Schott Aroideae, catalogada pelo número 6018 na edição microfichas - Schott 1984).

Ramos flageliformes longos. Caule cilindrico raramente levemente aplanado, 0.6- $0.8 \mathrm{~cm}$ diâm., de verde, verde escuro, castanho esverdeado a cor de palha, de opaco, levemente lúcido a, raramente, lúcido. Internós em plantas jovens $1.9-13.0 \mathrm{~cm}$ compr., em plantas adultas (0.6-)5.5-7.0(-11.0)cm compr., claros quando novos. Raízes adventícias novas de verde-amareladas a amarelas com o ápice rosado a vermelho, tornando-se castanho com o tempo, $1.0 \mathrm{~mm}$ diâm. Profilo membranáceo, verde claro com estrias verde escuras, caduco, $4.5-8.5 \mathrm{~cm}$ de compr. e $1.1-2.1 \mathrm{~cm}$ de larg. na base. Catafilo verde claro a verde com estrias mais escuras, com a face superior da bainha

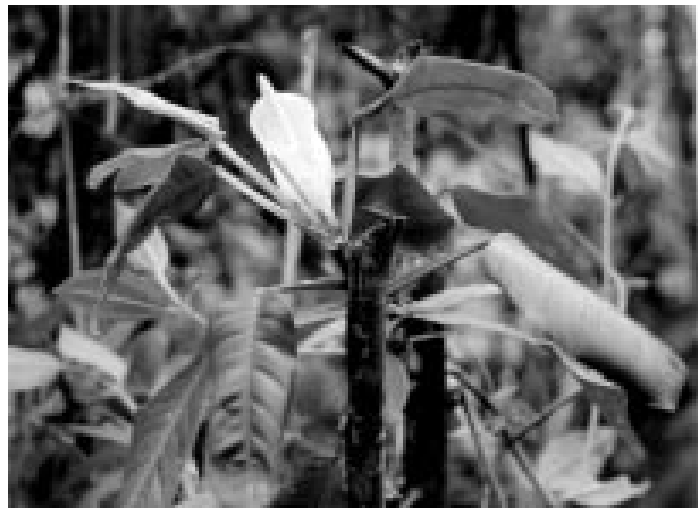

Figura 28 - Philodendron propinquum Schott - Hábito

mais lúcida. Pecíolo $6.0-9.5 \mathrm{~cm}$ compr. e adulto $5.7-23.5 \mathrm{~cm}$ compr. e $0.2-0.3 \mathrm{~cm}$ diâm. no ápice, de aplanado na face superior e arredondado na inferior a aplanado em ambas as superfícies, verde quando jovem com estrias de concolores a mais escuras na face superior, e mais escuras na face inferior. Bainha verde concolor com o pecíolo, lúcida a levemente lúcida na face superior e opaca na face inferior, 5.6-22.5cm compr. e 1.0-1.9 cm larg., distância até $1.0 \mathrm{~cm}$ da lâmina, podendo se prolongar até a inserção com a lâmina, levemente fechada na base do pecíolo e aberta e expandida até a 
Philodendron Schott (Araceae): morfologia e taxonomia das espécies da Reserva Ecológica de

base da lâmina, presença de lígula que pode ultrapassar a base da lâmina, face inferior distintamente estriada com linhas verdes escuras e mais claro sobre o eixo central. Lâmina foliar membranácea a levemente cartácea, jovem estreitamente lanceolada e longamente acuminada, $10.5-14.0 \mathrm{~cm}$ compr. e $2.5-3.5 \mathrm{~cm}$ larg., adulta lanceolada, oblongolanceolada a oblongo-elíptica, (10.0-)14.517.5(-25.5)cm compr. e 4.2-7.3(10.5)cm larg., verde com a face inferior mais clara, base levemente cordada a arredondada, acuminada, lúcida na face superior e opaca na inferior, lúcida em ambas as faces a raramente opaca em ambas as faces. Nervura central impressa na face superior e saliente na inferior, levemente mais clara a concolor na face superior e mais clara a levemente mais clara na superior. Nervuras laterais primárias 6-9 pares, levemente impressas na face superior e levemente salientes na inferior, levemente mais clara a concolor na superfície superior e mais clara a levemente mais clara na inferior em relação a lâmina. Simpódio floral com uma única inflorescência. Pedúnculo verde com estrias mais escuras, $2.0-4.0 \mathrm{~cm}$ compr. e 0.7 cm larg. Espata $8.0-16.5 \mathrm{~cm}$ compr. e $1.3 \mathrm{~cm}$ larg. na região mediana, cilíndrica, cuspidada, com leve diferenciação entre tubo e lâmina, externamente verde quando fechada e quando aberta de alba a creme esverdeada com muitas estrias verde escuras na base e uma linha dorsal verde escuro saindo da base até a região mediana, internamente creme com canais de resina amarelados, decorrência de $1.2-2.3 \mathrm{~cm}$ compr. Espádice $6.5-9.2 \mathrm{~cm}$ compr., presença de estípite de $1.0 \mathrm{~cm}$ compr., zona apical raramente com 3 estames parcialmente estéreis, zona masculina fértil creme, sem a presença de resina ferrugínea, $3.5-5.0 \mathrm{~cm}$ de compr. e $0.5-1.1 \mathrm{~cm}$ diâm., zona masculina estéril creme esbranquiçado, $0.5-1.0 \mathrm{~cm}$ compr. e 1.1-1.3cm diâm.,zona feminina esverdeada, 2.5-3.4cm compr. e 1.0-1.1 cm diâm. Estames 2(-3) por flor, $1.5-2.0 \mathrm{~mm}$ altura e $1.0-1.5 \mathrm{~mm}$ larg. no ápice. Estaminódios cremes, 2.02.3 $\mathrm{mm}$ altura e 0.9-2.0 $\mathrm{mm}$ larg. no ápice,

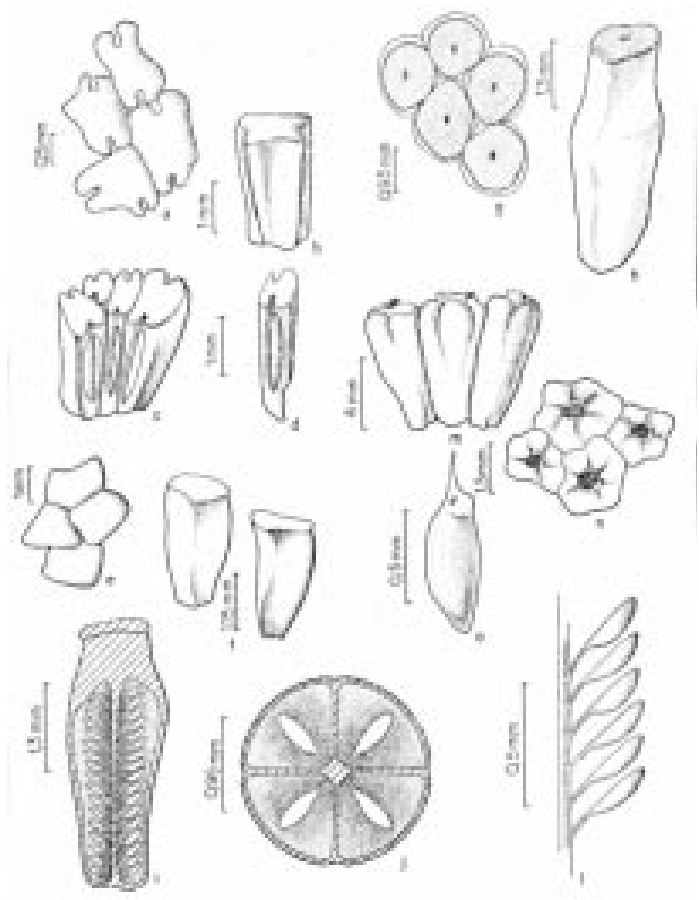

Figura 29 - Philodendron propinquum Schott. (Nadruz 1075, 1068, 1012) -a. Flores masculinas férteis, em vista apical, com 4 estames; b. Detalhe do estame em vista frontal; c. Flores masculinas férteis em vista lateral; d. Detalhe do estame em vista lateral; $\mathbf{e}$. Flores masculinas estéreis em vista apical; $\mathbf{f}$. Detalhe dos estaminódios em vista lateral; g. Flores femininas em vista apical; h. Detalhe do gineceu em vista frontal; i. Detalhe do gineceu em corte longitudinal mostrando lóculos com óvulos; $\mathbf{j}$. Detalhe do gineceu em corte transversal mostrando lóculos com óvulos; 1. Detalhe dos óvulos em placentação axilar; m. Bagas em vista frontal; n. Bagas em vista apical; o. Detalhe da semente.

afilando-se para a base. Gineceu com cerca de 2.0-3.9 mm altura e 1.0-1.9 mm larg. no ápice, ovário esverdeado oblongo a oblongoobovado, verde claro, lóculos 3-4, óvulos vários por lóculo, placentação axilar, estigma globoso de verde claro a castanho. Infrutescência madura com bagas verde amareladas, amarelas a laranjas, $5.5-7.5 \mathrm{~cm}$ compr. e $2.5 \mathrm{~cm}$ diâm. na região mediana, bagas $7.0-8.0 \mathrm{~mm}$ de compr. e $2.0-3.0 \mathrm{~mm}$ de larg. no ápice, com várias sementes, estigma persistente, sementes oblongas a oblongo-lanceoladas, $1.0 \mathrm{~mm}$ de compr. e $0.4-0.5 \mathrm{~mm}$ de larg. na região mediana. Algumas sementes foram observadas galhadas. 
Material Examinado: Rio de Janeiro, Nova Friburgo, Macaé de Cima: Sítio Sophronites, 26.07.88, Nadruz et al. 392 (RB); Sítio Sophronites, 22.11.88, Nadruz et al. 416 (RB); Sítio Sophronites, área do projeto mata atlântica, 07.03.89, Nadruz et al. 484 (RB); Idem, área da parcela, 23.03.92, Nadruz et al. 739 (RB); Sítio Bacchus, Estrada do Hotel Fazenda São João, 02.11.92, Nadruz et al. 756 (RB, K); Sítio Sophronites, mata atlântica de encosta, $\pm 1300 \mathrm{msm}, 22.03 .94$, Nadruz et al. 995 (RB); Estrada de Santa Fé, 19.04.94, Nadruz 1010 (RB); Estrada principal que corta a Reserva, entre Hotel São João e Sítio do João Luís, 19.04.94, Nadruz 1012 (RB); Idem, Idem, 19.04.94, Nadruz 1016 (RB); Estrada entre o hotel São João e o Sítio Fazenda Velha, na beira do Rio Macaé, 980msm, 29.09.94, Nadruz 1068 (RB); Estrada principal do Sítio Bacchus, 10.11.94, Nadruz 1075 (RB); Fazenda Ouro Verde, mata secundária, 25.06.93, Vieira s/n (RB); Friburgo, 20.11.22, Kuhlmann $\mathrm{s} / \mathrm{n}^{\circ}$ (RB).

Philodendron propinquum distribui-se pelos estados do Minas Gerais, Espírito Santo, Paraná e Rio de Janeiro nos municípios de Cachoeiras de Macacu, Itatiaia, Magé, Nova Friburgo, Nova Iguaçu, Petrópolis, Rio Bonito, Rio de Janeiro, Teresópolis.

Espécie hemiepífita ocorrente na floresta pluvial atlântica de encosta e baixo montana em locais úmidos e sombrios.

Pertencente ao subgênero Pteromischum e muito próxima de $P$. ochrostemon, $P$. sonderianum e $P$. obliquiifolium A sua característica principal é a bainha expandida e totalmente aberta, $P$. ochrostemon difere pela bainha fechada, $P$. sonderianum pela forma da folha oblongo-obovada e pelos óvulos dispostos em 4 séries, em $P$. propinquum dispostos em duas séries de acordo com Engler (1878) e Krause (1913) e P. obliquifolium pelo número maior de pares de nervuras laterais primárias (de 11-18).

A folha pode apresentar uma pequena variação na forma da lâmina que vai de oblongo-lanceolada a oblonga ou oblongo- ovada, o mesmo acontecendo com o tamanho do cúspide.

Schott ao descrever $P$. propinquum ignora sua característica mais marcante que é a bainha alada, mas ao citá-la mais tarde no Prodromus (Schott 1860), menciona "vagina latiuscula... explanata". Essa característica também é notada nos Ícones de Schott números 2415-2419.

Até então, P. ambiguum Schott vinha sendo tratada como uma espécie distinta dentro do subgênero Pteromischum. Através de estudos de comparação, tanto da bibliografia (Schott 1856, 1860; Engler 1878 e Krause 1913) quanto dos ícones de Schott números 3588, 3589, 3590 (P. ambiguum) e material de herbário, concluiu-se que as diferenças, como forma foliar e comprimento do estípite, não são suficientes para distinguir as duas espécies. Conforme mostra a descrição acima, a lâmina da folha pode sofrer uma variação considerável dentro do mesmo indivíduo. O mesmo acontece com o tamanho do estípite no espádice e essa variação é comum em várias espécies do gênero. Assim sendo optou-se pela sinonimização.

Em seu recente trabalho, Grayum (1996) notou a existência de dois materiais de Gardner no herbário K, possuindo o número 227, etiquetados como "sheet 1" e "sheet 2" mas com datas e localidades diferentes. Os mesmos foram combinados na composição da ilustração do ícone da espécie (Schott, 1984: 47 d7). A escolha do material denominado "sheet 1", para lectotipificação, deveu-se aos dados mais completos na etiqueta original e também das anotações de Schott.

De acordo com os critérios de conservação da natureza a espécie é considerada protegida por encontrar-se bem protegida em unidade de conservação e com muita ocorrência comprovada por coleções de herbário.

5.4.10 - Philodendron roseopetiolatum Nadruz \& Mayo, Bolm. Botânica Univ. São Paulo 17: 55. 1998. Typus: Brasil, Rio de 
Philodendron Schott (Araceae): morfologia e taxonomia das espécies da Reserva Ecológica de Macaé de Cima - Nova Friburgo, Rio de Janeiro, Brasil

Janeiro, Nova Friburgo, Macaé de Cima, Estrada entre Hotel São João e o Sítio Fazenda Velha, na beira do Rio Macaé, 980m, Nadruz 1063 et al., 26.IX.94 (Holotypus RB); Figs. 30,31 e 32 .

Caule cilíndrico, 1.7-2.7(-5.0)cm diâm., opaco, verde arroxeado, tornando-se verdeacastanhado a castanho claro. Internós 2.5$5.0 \mathrm{~cm}$ compr. Raízes adventícias avermelhadas quando novas, tornando-se castanhas, $0.2(-0.7) \mathrm{cm}$ diâm. Escamas intravaginais castanhas, triangulares, $0.15 \mathrm{~cm}$ compr., 0.1-0.2cm larg. na base. Profilo caduco, verde a creme-esverdeado com estrias verdes mais escuras a avermelhadas, 13.5 $15.0 \mathrm{~cm}$ compr., $1.3 \mathrm{~cm}$ larg. na base. Pecíolo 29.5-33.9(-57.0) cm compr., 0.5-0.9(-1.6) $\mathrm{cm}$ diâm., subroliço a aplanado na face adaxial e arredondado na face abaxial, rosado a roxoavermelhado na porção apical, com estrias verde escuras, levemente mais claras a avermelhadas no ápice. Bainha em unidade simpodial adulta em flor $3.0-6.5(-9.0) \mathrm{cm}$ compr., verde, fechada. Lâmina sagitada, 26.0$34.0 \mathrm{~cm}$ compr., $17.5-21.0 \mathrm{~cm}$ larg., cartácea, verde lúcida, clara, com linhas glandulares mais escuras na face abaxial, margem inteira, rosada a levemente avermelhada. Divisão

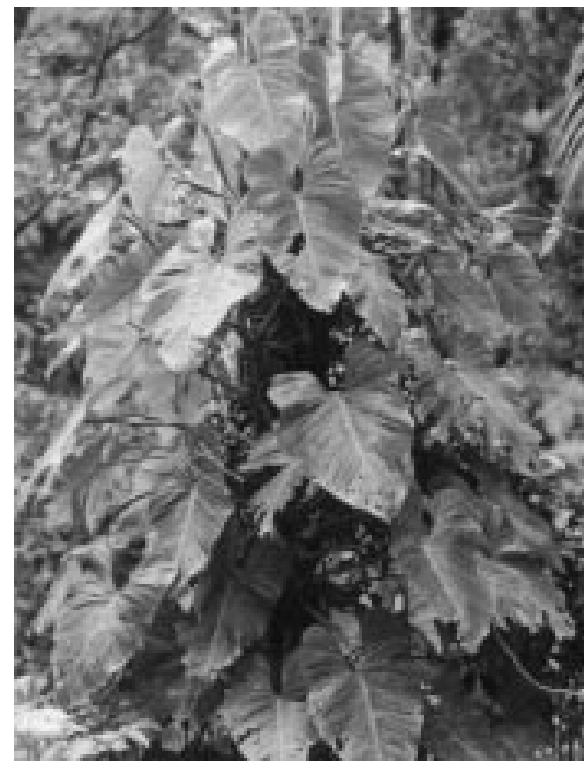

Figura 30 - Philodendron roseopetiolatum Nadruz \& Mayo - Hábito

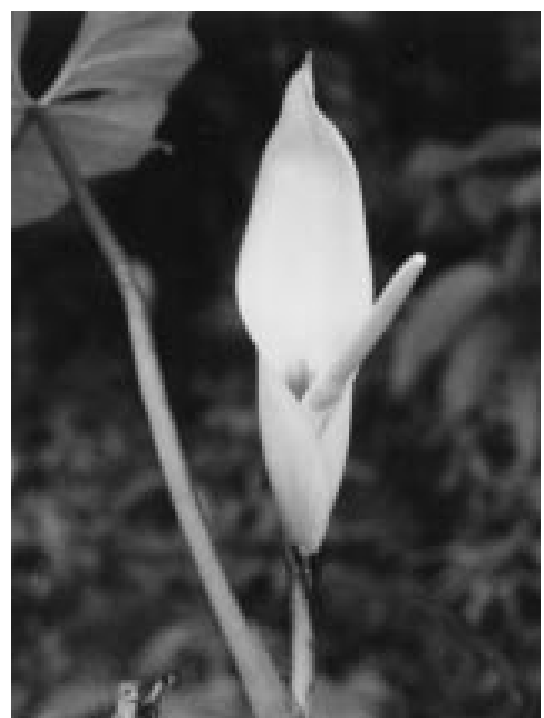

Figura 31 - Philodendron roseopetiolatum Nadruz \& Mayo - Detalhe da inflorescência

anterior $20.0-26.0 \mathrm{~cm}$ compr., $18.5-21.0 \mathrm{~cm}$ larg., ápice agudo, cuspidado. Nervura central pouco mais clara que a lâmina, impressa na face adaxial, concolor a levemente discolor, rosada a verde, saliente na face abaxial. Nervuras laterais primárias 4 pares, levemente discolores e impressas na face adaxial, concolores a levemente discolores e salientes na face abaxial. Nervuras laterais interprimárias evidentes. Divisão posterior com lobos não superpostos, retrorsos, $11.5-12.5 \mathrm{~cm}$ compr., $19.0-23.5 \mathrm{~cm}$ larg., denudação no lado basioscópico de 1.0-1.5cm compr., nervuras primárias acroscópica 1 e basioscópicas 1-2. Sinus parabólico oblongo. Simpódio floral com até 4 inflorescências. Pedúnculo verde a verde claro, vinoso no ápice, com estrias mais claras tornando-se avermelhadas na junção com a espata, $3.5-5.0(-7.0) \mathrm{cm}$ compr., $0.8-1.0 \mathrm{~cm}$ diâm. Espata 15.0-19.5cm compr., 0.9-1.1cm larg. na região mediana, com leve estrangulamento mediano, com nuança vináceo e estrias mais claras no tubo e alvo a levemente rosado na lâmina ou com nuanças irregulares vermelhos arroxeados no dorso formando anel vinoso na base externamente, carmim no tubo e branco na lâmina internamente. Espádice cilíndrico, séssil, (12.5-)14.0-19.0cm compr., zona estaminada estéril apical creme 
amarelada (1.0-)3.3-5.0cm compr., 0.6-0.7cm diâm., zona estaminada fértil cremeesbranquiçada, com canais de resina abaixo dos estames, $3.7-5.2 \mathrm{~cm}$ compr., $0.8(-1.3) \mathrm{cm}$ diâm., zona estaminada estéril basal branca, 1.0-1.2(-1.4)cm compr., 1.1-1.2(-1.5)cm diâm., zona pistilada verde 4.9-5.2(-7.0) cm compr., 1.0-1.1(-1.6) cm diâm., área da zona pistilada adnata com a espata $2.5-3.3 \mathrm{~cm}$ compr. Estames 3-4(-6) por flor, 1.5mm altura, 0.9$1.5 \mathrm{~mm}$ larg. na região apical. Estaminódios basais $1.8-4.0 \mathrm{~mm}$ compr., $1.0-3.7 \mathrm{~mm}$ larg. na região apical; apicais 1.8-1.9mm compr., 1.0$2.5 \mathrm{~mm}$ larg. na região apical. Gineceu $2.5 \mathrm{~mm}$ compr., $1.5-2.0 \mathrm{~mm}$ larg. na região mediana, lóculos 7-9, óvulos 3-4 por lóculo, saindo do mesmo ponto próximo a base do septo, $0.6 \mathrm{~mm}$ compr., com tricomas nos funículos. Frutos pouco maduros de cor verde. Infrutescência 5.5-6.3cm compr., $2.0-2.3 \mathrm{~cm}$ diâm., sementes brancas, oblongas $0.4 \mathrm{~cm}$ compr.

Material examinado: Brasil, Rio de Janeiro, Nova Friburgo, Distrito de Macaé de Cima: Sitio Sophronites, área do Projeto Mata Atlântica, 07.III.89, Nadruz 482 et al (RB); idem, Nadruz 486 et al. (RB); Sitio Sophronites, 26.II.92, Nadruz 738 et al. (RB); Estrada que leva até a entrada do Sitio Sophronites, 03.XI.92, Nadruz et al. 774 (RB, $\mathrm{K})$. Estrada principal que corta a Reserva, entre Hotel Fazenda São João e sítio do João Luís, beirando o Rio Macaé, 19.IV.94, Nadruz 1019 (RB)

Philodendron roseopetiolatum foi, até o momento, coletado apenas no Município de Nova Friburgo, Estado do Rio de Janeiro. Espécie hemiepífita da floresta atlântica pluvial de encosta, em locais bastante sombreados e úmidos, podendo chegar a $1100 \mathrm{~m}$.

Espécie próxima de $P$. appendiculatum, sendo perfeitamente diferenciada pelo pecíolo rosado, em direção ao ápice, pela coloração interna carmim do tubo da espata e ausência do estrangulamento acentuado mediano entre a espata e o espádice.

O epíteto específico refere-se a um dos aspectos mais marcantes desta espécie, ou seja,

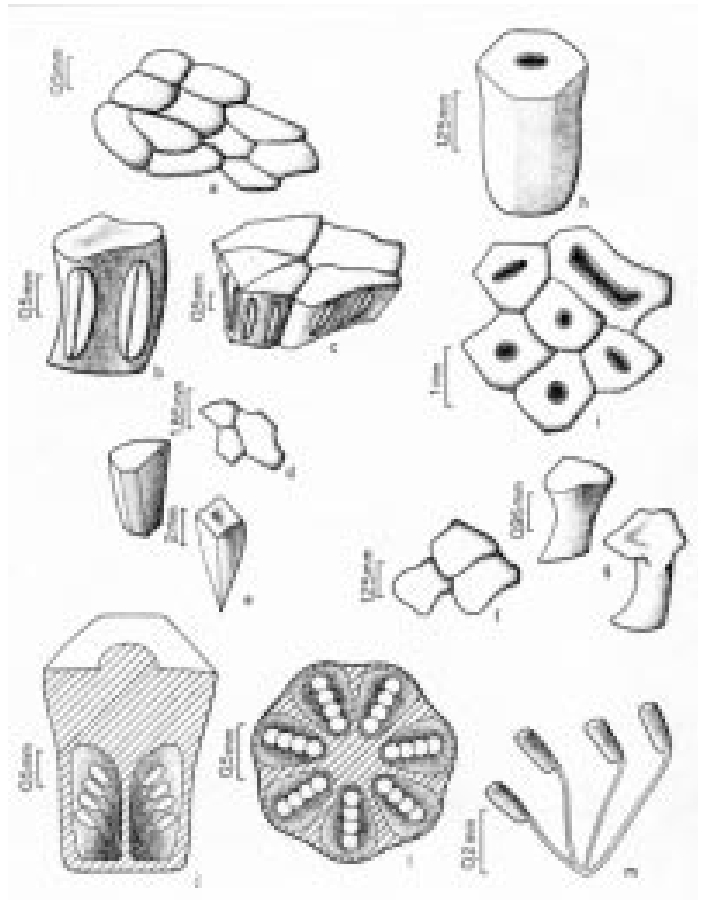

Figura 32 - Philodendron roseopetiolatum Nadruz \& Mayo (Nadruz 1009, 774, 738, 482) - a. Flores masculinas férteis, em vista apical, com 3-5 estames; $\mathbf{b}$. Detalhe do estame em vista frontal; c. Detalhe da flor masculina com 4-5 estames; d. Flor masculina estéril apical em vista apical; e. Detalhe de estaminódios apicais em vista frontal; f. Flor masculina estéril basal em vista apical; g. Detalhe de estaminódios basais em vista frontal; $\mathbf{h}$. Detalhe do gineceu em vista frontal; i. Flores femininas em vista apical; j. Detalhe do gineceu em corte longitudinal mostrando lóculos com óvulos; l. Detalhe do gineceu em corte transversal mostrando lóculos com óvulos; m. Detalhe dos óvulos.

os pecíolos rosados. De acordo com os critérios de IUCN, a espécie é considerada protegida por encontrar-se em unidade de conservação e de ocorrência freqüente comprovada pelas coleções de herbário.

\section{Conclusões}

Os estudos que vem sendo realizados na Reserva Ecológica de Macaé de Cima, desde 1986, registra, até o momento, a ocorrência de 10 espécies do gênero Philodendron para a área. Esse levantamento é um estudo preliminar, já que se pretende realizar um inventário da família na Reserva.

Uma das espécies registradas, para a Reserva Ecológica de Macaé de Cima, baseada numa coleção de Glaziou (Krause, 
Philodendron Schott (Araceae): morfologia e taxonomia das espécies da Reserva Ecológica de

1913), foi Philodendron crassinervium Lindl. Espécie freqüente em restinga e matas próximas ao mar, não foi encontrada após várias visitas à área da Reserva, onde concluise que o exemplar não ocorre em áreas serranas, sendo errônea a informação de sua ocorrência na área citada.

O gênero Philodendron é representado na área por 2 subgêneros: subgênero Philodendron onde enquadra-se $P$. edmundoi na seção Baursia, as espécies $P$. appendiculatum, $P$. altomacaense, $P$. fragile, $P$. hatschbachii, $P$. eximium e $P$. roseopetiolatum na seção Calostigma e $P$. ornatum na seção Philodendron e subgênero Pteromischum com as espécies $P$. ochrostemon e P. propinquum. Pode-se esclarecer a identificação correta com relação as espécies do subgênero Pteromischum, isto é, as espécies $P$. ochrostemon e $P$. propinquum, erroneamente denominadas como $P$. sonderianum e $P$. ochrostemon respectivamente, e a sinonimização de $P$. ochrostemon com $P$. ambiguum é apresentada.

As espécies $P$. appendiculatum, $P$. altomacaense, $P$. fragile, $P$. hatschbachii e $P$. roseopetiolatum foram consideradas novas para a ciência e $P$. edmundoi teve sua segunda coleta após o tipo, constatando-se uma nova ocorrência no estado.

Com relação a distribuição geográfica das espécies, observou-se que $P$. altomacaense, $P$. fragile e $P$. roseopetiolatum são endêmicas à área da Reserva Ecológica de Macaé de Cima, P. edmundoi e P. hatschbachii ocorrem somente nos estados do Espírito Santo e Rio de Janeiro e $P$. eximium além dos estados do Rio de Janeiro e São Paulo, também foi encontrado em Pernambuco (matas de brejo) mostrando a importância do estudo da biologia da dispersão das Aráceas sul-brasileiras para o conhecimento da dispersão de sementes dessas espécies através de barreiras de vegetação ou de clima (Mayo, 1984). $P$. appendiculatum é encontrada nos estados do sudeste, Paraná e Santa Catarina. P. ochrostemon distribui-se pelos estados de Roraima, Minas Gerais, Espírito Santo, Rio de Janeiro, São Paulo e Rio Grande do Sul. $P$. propinquum e $P$. ornatum apresentam distribuição mais ampla, desde Pernambuco até Santa Catarina, estendendo-se até o Acre, Amazonas, Roraima, Pará e Mato Grosso. Todas as espécies de Macaé de Cima são predominantes em mata de encosta.

As 10 espécies estudadas possuem o hábito hemi-epífito secundário, ou seja, iniciam suas vidas na terra, trepando, em seguida, nas árvores onde, quando em estágio adulto, perdem a ligação com o solo (Putz \& Holbrook 1986, Kress 1986). Pouco se sabe sobre o padrão de crescimento hemi-epífito secundário sendo necessário maiores observações de campo para a confirmação do desenvolvimento destas espécies (Putz \& Holbrook 1986). A única exceção foi $P$. altomacaense que apresentou-se, também, como terrestre.

Foram utilizados, para a separação e identificação das espécies, caracteres vegetativos como forma de lâmina foliar (muito variável no gênero Philodendron), forma e ornamentação do pecíolo, e caracteres reprodutivos tais como número de inflorescências por simpódio floral (podendo chegar até 5), coloração e grau de constrição da espata, número de lóculos e óvulos no ovário e a presença ou ausência de tricomas no funículo dos óvulos. A coloração dos frutos maduros certamente contribuiria para a separação das espécies mas, infelizmente, somente nas espécies $P$. propinquum, $P$. ochrostemon e P. altomacaense foram observados. No caso dos frutos de P. ochrostemon encontravam-se disformes, de coloração branca e de consistência maciça no seu interior, devido a desova realizada, provavelmente, por vespas dentro do ovário na fase receptiva do estigma, provocando a formação de galhas (Mayo, 1986b).

Segundo Mayo (1989) a presença de tricomas no funículo dos óvulos é um caráter comum no gineceu das Aráceas, mas através de observações feitas com as espécies em 
estudo foram notados a ocorrência desses pêlos somente em três espécies ( $P$. altomacaense, $P$. eximium e $P$. fragile) dentre as dez. Sugere-se um estudo detalhado para determinar, com mais exatidão, o ocorrência dos tricomas na família.

Tendo em vista que a última revisão geral do gênero Philodendron foi realizada por Krause em 1913, são grandes os problemas na sistemática de suas espécies, tornando-se necessária a consulta de material tipos em forma de estampas ou obras princeps, já que muitos espécimes tipos em herbários europeus foram destruídos durante a segunda guerra mundial.

Em relação as espécies consideradas endêmicas esta colocação deve ser considerada provisória. Até o momento poucas coletas foram efetuadas para o grupo, sendo assim imprescindível a continuação do trabalho de campo nas áreas e municípios adjacentes para se certificar da distribuição das mesmas e sua classificação na categoria de "em perigo" pelos critérios da IUCN.

Como a grande maioria das espécies do gênero Philodendron são de áreas sombreadas e úmidas, não suportando viver em locais secos ou degradados e sua grande diversificação dá-se na floresta pluvial tropical, a conservação destas áreas é imprescindível para a preservação dessas espécies.

Das cinco espécies novas descritas para a área, quatro - $P$. altomacaense, $P$. roseopetiolatum, $P$. appendiculatum, $P$. hatschbachii são consideradas freqüentes por serem encontradas em vários pontos de coletas. P. fragile, porém, é muito pouco freqüente sendo encontrada somente em dois pontos de coleta. P. edmundoi foi registrada pela segunda vez no estado após sua publicação. Isso mostra quanto é insuficiente o conhecimento sobre as espécies de Araceae na Mata Atlântica.

Todas as espécies ocorrentes na Reserva foram consideradas potencialmente ornamentais, como a grande maioria das espécies da família Araceae, tendo em vista seus portes e suas folhas vistosas sem mencionar suas inflorescências tão características.

\section{AGRADECIMENTOS}

À Prof.a Dr.a Graziela Maciel Barroso pela orientação e incentivo nos trabalhos com a família Araceae; ao Prof. Dr. Simon J. Mayo pela valiosa coorientação e amizade ao longo das pesquisas com o grupo; aos amigos Dra. Denise P. da Costa, Prof. Bruno C. Kurtz, Prof $\stackrel{a}{\mathrm{a}}$ Angela S. da F. Vaz, Prof $\stackrel{a}{\mathrm{a}}$ Andrea Kurtz, Prof. Dr. Jorge Fontella Pereira, Dra. Nilda Marquete, Dra. Maria da Conceição Valente e Prof ${ }^{\mathrm{a}}$ Marli Pires M. de Lima pelas valiosas críticas e sugestões dadas; às Dras. Cássia Sakuragui (Universidade Estadual de Maringá), Prof ${ }^{a}$ Flávia C. Ramalho (Universidade Federal Rural de Pernambuco) e Prof ${ }^{\mathrm{a}}$ Dra. Regina Helena Potsch pela amizade, incentivo e sugestões em todos os momentos; ao Prof. Eduardo Dalcin, Prof ${ }^{a}$ Adriana Schnoor e toda a equipe do CISMA/NCC (Jardim Botânico do Rio de Janeiro) pela ajuda na organização dos dados em computador; aos amigos David e Isabel Miller pela amizade e apoio nas excursões à Reserva Ecológica de Macaé de Cima; à Coordenação do Programa Mata Atlântica (IBAMA/SHELL) pelo apoio na realização das excursões; à ilustradora Maria Teresa Reif pelas maravilhosas estampas em aquarela e nanquim; ao Prof. Dr. Jorge Pedro Pereira Carauta pela ajuda na organização nomenclatural de algumas espécies; aos coletores Jorge Caruso e Luiz Cláudio S. Silva pela ajuda na coleta dos materiais; aos curadores dos herbários nacionais e estrangeiros e suas equipes no pronto atendimento no envio dos materiais botânicos solicitados; às bibliotecas do Jardim Botânico do Rio de Janeiro, Museu Nacional do Rio de Janeiro e do Royal Botanic Gardens, Kew pelo carinho e atenção dos seus funcionários no empréstimo e envio das bibliografias tão necessárias a realização deste trabalho; aos colegas da turma de mestrado que sempre estiveram prontos para apoiar e incentivar; ao 
PhilodendronSchott (Araceae): morfologia e taxonomia das espécies da Reserva Ecológica de

Macaé de Cima - Nova Friburgo, Rio de Janeiro, Brasil

CNPq e FAPERJ pelo apoio financeiro; à Fundação Botânica Margaret Mee pela bolsa concedida para os trabalhos realizados no Royal Botanic Gardens, Kew; à Coordenação de Pós-Graduação em Botânica do Museu Nacional pelo pronto atendimento às necessidades que, porventura, apareceram para a realização da dissertação.

\section{REFERÊNCIAS BIBLIOGRÁFICAS}

Barroso, G.M. 1957. Araceae Novae. Arch. Jard. Bot. Rio de Janeiro 15 :89-112.

Blume, C.L. 1837. Rumphia $1: 73-154$, tt. 27 37, 65-66, Leiden.

Bogner, J. 1987. Morphological Variation in Aroids. Aroideana 10(2) :4-16.

Bown, D. 1988. Aroids - Plants of the Arum family. Timber Press, Portland, Oregon, London. p.256.

Bunting, G.S. 1975. Nuevas especies para la revision de las Araceas venozolanas. Acta Bot. Venez. 10 (1-4): 263-335. 1980. Sinopsis de las Araceae de Venezuela. Revista Fac. Agron. Univ. Nac. La Plata (Maracay) 10 (14): 139-290.

1984. Philodendron. In S.M. Walters et al. (eds.) European Garden Flora vol. II. Monocotyledons. (Part II): 91-94.

1986. New taxa of Venezuelan Araceae. Phytologia 60(5): 293-344.

. 1987. Two news species of Brazilian Philodendron (Araceae). Phytologia 61(7): 441-443.

1988. New taxa of Venezuelan Araceae (II). Phytologia 64: 466-478 [Philodendron only].

Carauta, J.P.P. 1989. Ficus (Moraceae) no Brasil: Conservação e taxonomia. Albertoa 2: 317-322.

Coelho, M.A.N. 1998. Cinco espécies novas do gênero Philodendron Schott (Araceae) para o Brasil. Bolm. Botânica Univ. São Paulo 17: 47-60.

Croat, T.B. 1985. Collecting and preparing specimens of Araceae. Ann. Missouri Bot. Gard. 72 :252-258.

1986. A Revision of Philodendron (Araceae) for Central America and the West Indies. Manuscrito. 45pp. 1988. Ecology and Life Forms of Araceae. Aroideana 11(3) 53pp., il.

Departamento Nacional De Meteorologia 1992. Normais Climatológicas 1961-1990. Brasília. Secretaria Nacional de Irrigação. Ministério da Agricultura e Reforma Agrária. 83p.

Endlicher, S. 1837. Genera plantarum 1(3):237. Engler, A. 1878. Araceae. In C.F.P. von Martius, Flora Brasiliensis 3(2): 25-224, tt. 2-52. F. Fleischer, Leipzig.

Engler, A. 1879. Araceae. In A. \& C. De Candolle, Monographiae Phanerogamarum 2: 1-681, Masson, Paris.

1899. Beiträge zur Kenntnis der Araceae IX. 16. Revision der Gattung Philodendron Schott. Bot. Jahrb. Syst. $26: 509-564$.

Gottsberger, G. \& Amaral, A. 1984. Pollination strategies in Brazilian Philodendron species. Ber. Deutsch. Bot. Ges. 97 (34) :391-410.

Grayum, M.H. 1990. Evolution and Phylogeny of the Araceae. Ann. Missouri Bot. Gard. 77 :628-697.

1996. Revision of Philodendron Subgenus Pteromischum (Araceae) for Pacific and Caribbean Tropical America. Systematic Botany Monographs 47: 1-233.

Holmgren, P.K.; Keuken, W. \& Schofield, E.K. 1981. Index Herbariorum. Part I. The Herbaria of the World. 7 ed. F. A. Stafleu Editor geral, Bohn, Schelthema \& Holkema, Utrecht/Antwerpen; W. Junk B. V., Publishers, The Hague/Boston, 452pp.

Hueck, K. 1972. As Florestas da América do Sul. Ed. Universidade de Brasília, Ed. Polígono S.A., São Paulo, 466pp., il. 
Koch, C. 1853. Zantedeschia asperata. In: A. Braun, Klotzsch, C. Koch et Bouché, Index Seminum in horto berolinense anno 1853 collectorum. Appendix specierum novarum et minus cognitarum quae in Horto Regio Botanico Berolinense Coluntur, p.15 [p.5 of reprint edition]. Berlin

. 1855. Philodendron asperatum.

In: C. Koch Index Seminum in horto botanico berolinense anno 1855 collectourm. Appendix Generum et Specierum novarum et minus cognitarum, quae in Horto Regio Botanico Berolinense Coluntur, p.4. Berlin . 1855. Philodendron saueranum.

In: C. Koch Index Seminum in horto botanico berolinense anno 1855 collectorum. Appendix Generum et Specierum novarum et minus cognitarum, quae in Horto Regio Botanico Berolinense Coluntur, p.3. Berlin

Koch, C. \& Sauer, F.L.F. 1854. Philodendron eximium. In: C. Koch index seminum in horto botanico berolinense anno 1854 collectorum. Appendix Generum Specierum novarum et minus cognitarum, quae in Horto Regio Botanico Berolinense Coluntur, p.8. Berlinn

Kramer, J. 1974. Philodendron. Scribners Sons, New York. 87pp.

Krause, K. 1913. Araceae-PhilodendroideaePhilodendrinae. In A. Engler (ed.), Das Pflanzenreich 60 (IV.23Db) :1-143. W. Engelmann, Leipzig.

Kress, W.J. 1986. The systematic distribution of vascular epiphytes: An update. Selbyana 9 :2-22.

Kunth, C.S. 1841. Enumeratio Plantarum... 3 :46-52, Stuttgart et Tübingen.

Lawrence, G.H.M.; Buchhein, A.F.G.; Daniels, G.S. \& Dolezal, H. (Eds.). 1968. Botânico - Periódico - Huntianum. Hunt Botanical Library, Pittsburgh, Pa., 1063pp.

Lima, H.C. de \& Guedes-Bruni, R.R. 1997. Serra de Macaé de Cima: Diversidade Florística e Conservação em Mata
Atlântica. Rio de Janeiro, Instituto de Pesquisas Jardim Botânico do Rio de Janeiro, 345p.

Mayo, S.J. 1985. Araceae In R.M. Polhill (ed.), Flora of Tropical East Africa. Rotterdam/ Boston: A.A. Balkema. . 1986a. Araceae. In F. Cope \& D. Philcox (Eds.), Flora of Trinidad \& Tobago, Vol. III, part IV, :291-367. Ministry of Agriculture, Lands and Food Production, Trinidad.

1986b. Systematics of

Philodendron Schott (Araceae) with special reference to inflorescence characters. Ph.D. Thesis, Univ. Reading, UK.

. 1988. Aspectos da evoluçäo e da geografia do gênero Philodendron Schott (Araceae). Acta Bot. Bras.1(2) :27-40. Supl.

. 1989. Observations of gynoecial structure in Philodendron (Araceae). Bot. J. 100 :139-172. 31 figs. . 1990a. History and infrageneric nomenclature of Philodendron (Araceae). Kew Bulletin 45(1) :37-71. . 1990b. Problems of speciation, biogeography and systematics in some Araceae of the Brazilian Atlantic Forest. in Watanabe, S. et al., Anais do II Simpósio de Ecossistemas da Costa Sul e Sudeste Brasileira, São Paulo, Brasil $1: 235-258$.

. 1991. A revision of Philodendron subgenus Meconostigma (Araceae). Kew Bull. 46(4) :601-681.

, Coelho, M.A.N., Ramalho, F.C. et Sakuragui, C. 1994. Checklist das Araceae do Brasil. Manuscrito, versão 6, 74pp.

, Bogner, J. \& Boyce, P.C. 1997. The Genera of Araceae. The european Union by Continental Printing, Belgium. 370pp.

Nicolson, D.H. 1960. A brief review of classifications in the Araceae. Baileya $8(2): 62-67$. 
Philodendron Schott (Araceae): morfologia e taxonomia das espécies da Reserva Ecológica de

Nimer, E. 1989. Climatologia do Brasil. IBGE, Departamento de Recursos Naturais e Estudos Ambientais, 2 ${ }^{a}$ ed., 422pp., il.

Oliveira, V. et al. 1983. Pedologia. Levantamento Exploratório de Solos. In: Projeto RadamBrasil, Levantamento de Recursos Naturais vol. 32, folhas SF 23/ 24, Rio de Janeiro/Vitória, :385-552.

Peyritsch, J.J. 1879. Aroideae Maximilianae, Vienna, Gerold.

Plowman, T. 1969. Folk Uses of New World Aroids. Econ. Bot. 23 :97-122.

Programa Mata Atlântica. 1990. Relatório final. Jardim Botânico do Rio de Janeiro/ IBAMA, Linhas de Ação em Botânica/ CNPq, Instituto Pró-Natura, The John D. \& Catherine T. MacArthur Foundation, Shell Brasil S.A., 220pp.

Putz, F.E. \& Holbrook, N.M. 1986. Notes on the natural history of hemiepiphytes. Selbyana 9 :64-69.

Schott, H.W. 1832. Araceae. In H.W. Schott \& S. Endlicher, Meletemata Botanica, :16-22 [Philodendron:19-20], Vienna. . 1853. Pflanzenskizzen. Oesterr. Bot. Wochenbl. III (48) :378. . 1856. Synopsis Aroidearum, $140 \mathrm{pp}$. typis congregationis mechitharisticae, Vienna. . 1857. Icones Aroidearum, 40 plates, Vienna. . 1859. Aroideenskizzen. Oesterr. Bot. Z.IX (3) :99.

. 1860. Prodromus Systematis Aroidearum, typis congregationis mechitharisticae, $602 \mathrm{pp}$. Vienna.

1865. Philodendron imperiale Schott in: Oestrr. Bot. Z. 15 :71. . 1865. Philodendron dolosum Schott in loc. cit. $15: 71$. 1984. Icones Aroideae et Reliquiae. Microfiche Edition, index editado por D.H. Nicolson, IDC AG, Zug, 29pp.

Stafleau, F.A. 1967. Taxonomic Literature. Inter - Documentation Company A.G.,
Zug, Switzerland, 556pp.

Stearn, W.T. 1993. Botanical Latin, ed. 4, David \& Charles, Newton Abbot. Great Britain, 566pp.

Stellfeld, C. 1950. As Aráceas da "Flora Fluminensis". Arq. Mus. Paranaense 8 :165-188.

Vellozo, J.M. da C. 1831 (1827). Araceae in: Flora Fluminensis. Icones 9, t.112.

1881. Florae

Fluminensis Icones. Paris, 9, tab. 112. 1831 (1827); in Arch. Mus. Nac. Rio de Janeiro 5 :387. 1881. 
